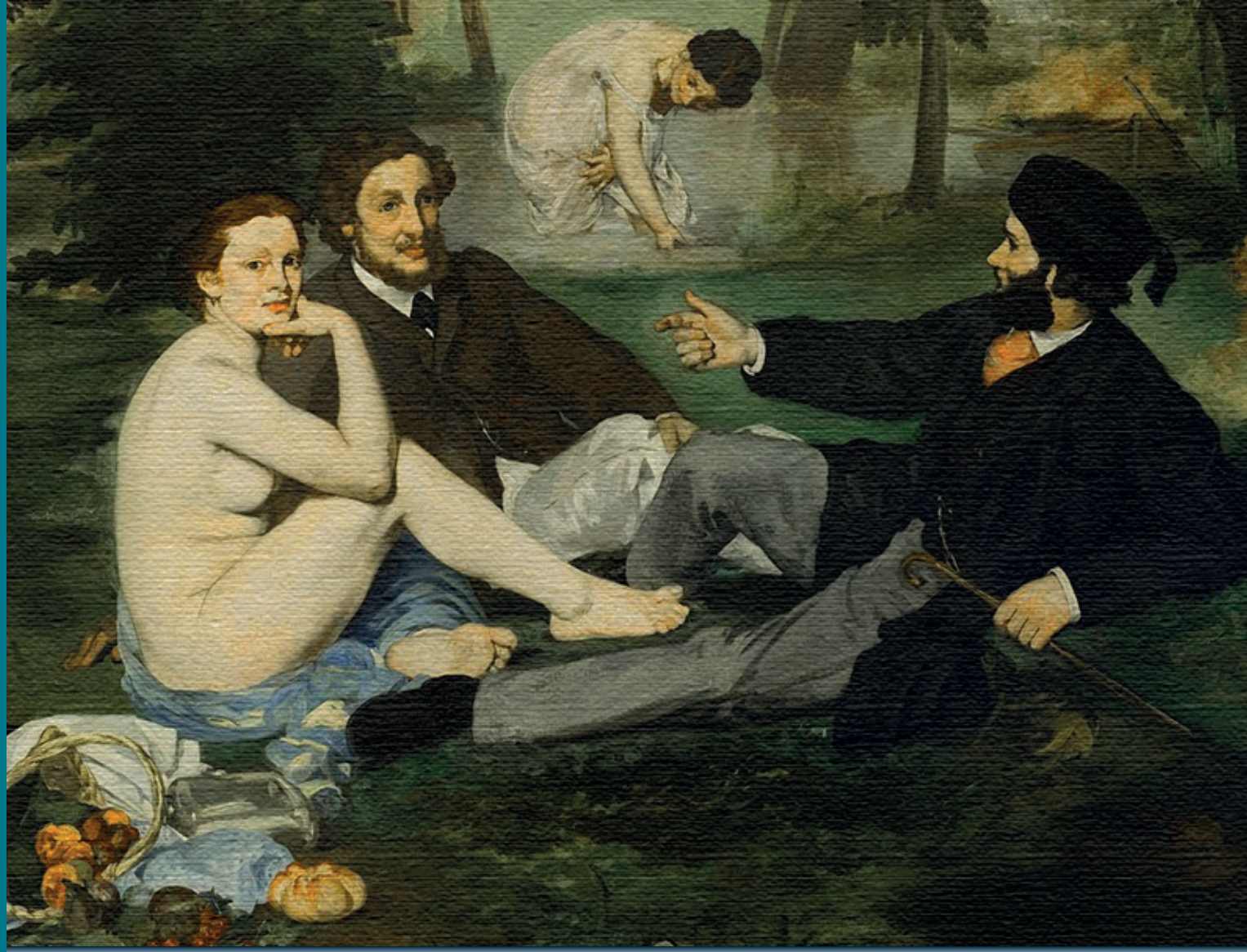

\title{
FLAUBERT EL CORAJE DE LA ESTÉTICA
}

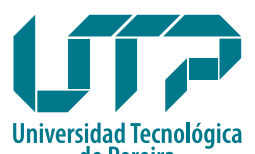
de Pereira

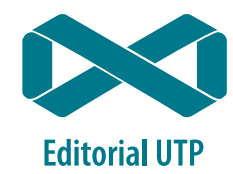

Editorial UTP
Antonio Rodríguez Jaramillo 


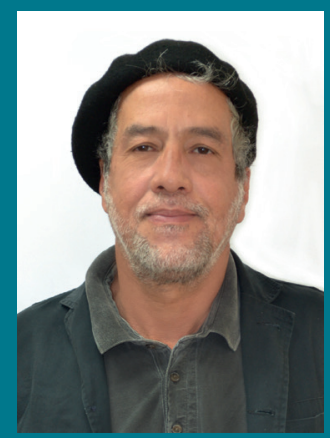

Antonio Rodríguez Jaramillo (Cali, Valle del Cauca, Colombia, 1958)

Doctor en filosofía del Instituto de Filosofía de la Universidad de Antioquia, Licenciado en Filosofía de la Universidad del Valle. Profesor Titular de la Facultad de Bellas Artes y Humanidades de la Universidad Tecnológica de Pereira.

Autor de los libros : Montaigne. Ética en diálogos modernos: los Ensayos; (2015), "Yo soy un moralista". Foucault, las alethurgias,( 2018).

Su tesis doctoral recibió la distinción Cum Laude.

Pertenece al grupo de investigación Estética y Expresión de la Universidad Tecnológica de Pereira.

antor@utp.edu.co 


\section{FLAUBERT \\ EL CORAJE DE LA ESTÉTICA}

Antonio Rodríguez Jaramillo

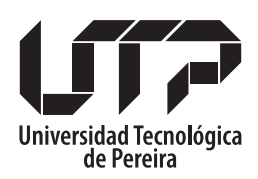

Facultad de Bellas Artes y Humanidades

Colección Trabajos de Investigación

2020 
Rodríguez Jaramillo, Antonio

Flaubert el coraje de la estética / Antonio Rodríguez

Jaramillo. - Pereira : Universidad Tecnológica de Pereira, 2020

178 páginas. - (Colección Trabajos de investigación).

ISBN: 978-958-722-467-2

elSBN: 978-958-722-468-9

1. Estética del arte 2. Flaubert, Gustave 1821-1880 3. Ética -

Moral 4. Análisis del discurso 5. Política - Moral 6. Movimientos

Literarios franceses 7. Verdad 8. Cinismo 9. Ideología social

CDD. 843.8

\section{FLAUBERT EL CORAJE DE LA ESTÉTICA}

(c) Antonio Rodríguez Jaramillo

(C) Universidad Tecnológica de Pereira

ISBN: 978-958-722-467-2

eISBN: 978-958-722-468-9

Imágen de Cubierta: Fragmento de obra Almuerzo en la hierba, Manet.

Trabajo de Investigación: Alethurgias II. Experiencias histórico-críticas de la vida, cod:

$1-16-10$

Universidad Tecnológica de Pereira

Vicerrectoría de Investigaciones, Innovación y Extensión

Editorial Universidad Tecnológica de Pereira

Pereira, Colombia

Coordinador editorial:

Luis Miguel Vargas Valencia

luismvargas@utp.edu.co

Teléfono 3137381

Edificio 9, Biblioteca Central "Jorge Roa Martínez"

Cra. 27 No. 10-02 Los Álamos, Pereira, Colombia

www.utp.edu.co

Montaje y producción:

María Alejandra Henao Jiménez

Universidad Tecnológica de Pereira

Pereira

Impresión y acabados

Graficas Olimpica

Pereira 
[... ¿quién sabe entonces si no habría medio de encontrar a través de la estética lo que el estoicismo había inventado para la moral?

Gustave Flaubert

Quijote y Sancho son más reales que el soldado español que los inventó, pero ninguna criatura de Flaubert es real como

Flaubert

JoRge Luis Borges 



\section{CONTENIDO}

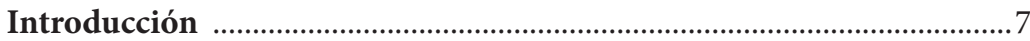

Capítulo uno.

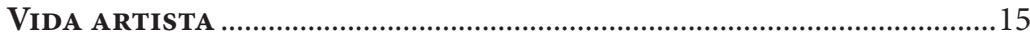

1.1. La idea de vida-artista.............................................................................

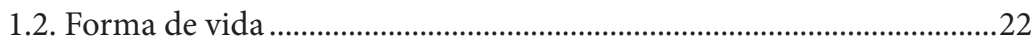

1.3. Gustave Flaubert en su «triste boutique» ...................................................32

Capítulo dos.

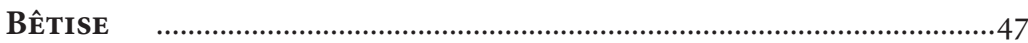

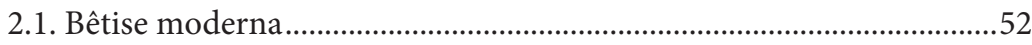

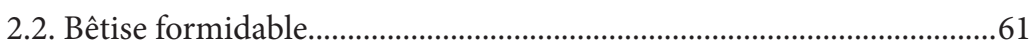

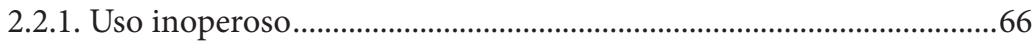

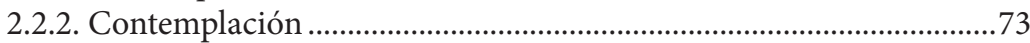

Capítulo tres.

MORALIS AESTHETICA........................................................................79

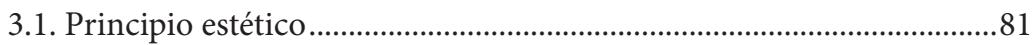

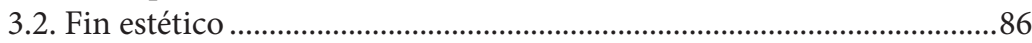

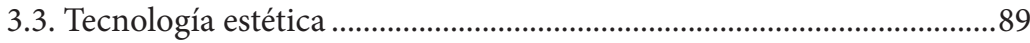

3.3.1. Contemplación del mal ....................................................................94

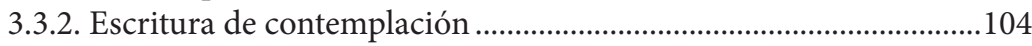

Capítulo cuatro.

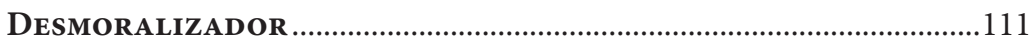

4.1. «No haré más que decir la verdad» ....................................................112

4.2. Anatomía de la bêtise...........................................................................119

4.3. Modo del pensamiento ............................................................................... 123

Capítulo cinco.

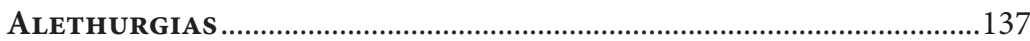

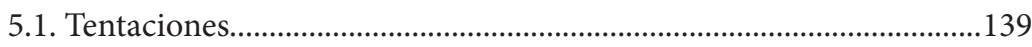

5.1.1. La chrêsis de la ascesis ......................................................................142

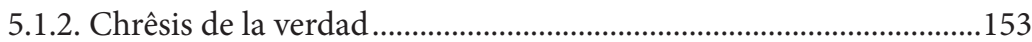

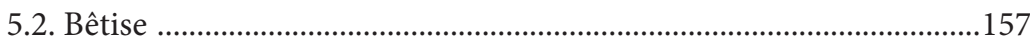

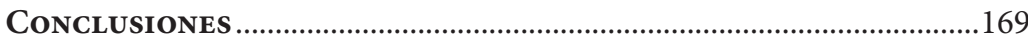

REFERENCIAS BIBLIOGRÁFICAS _.........................................................173 



\section{Introducción}

Se abren las puertas del siglo xIX y aparece el último Fausto (de Goethe) haciendo visible su gesto transido por la posesión del conocimiento de la verdad adquirido y la ausencia de la espiritualidad de la verdad necesitada. Grave, su melancolía bordea el enclave de las relaciones de la verdad con el modo de vida. Un acontecimiento en la cultura occidental: por una puerta, entra precipitado el filósofo a un lugar sin riesgo, el legendario héroe de la verdadera vida entra en la institución, deviene en funcionario público y gestor del consenso de la cultura; por otra, sale un nuevo personaje de la verdadera vida, el héroe de la vidaartista comportando su divisa anti-cultural.

El tema de vida-artista, en el siglo XIX, es susceptible de ser abordado más como un tipo de práctica ética que como representación romántica o ideológica. Vida-artista: ética de la verdad, de la verdad en cuanto pliegue de la estética. La experiencia ética de una verdad estética parece conducirse por tres principios: 
primero, la verdad del arte es capaz — suficiente- de dar una forma a la vida del artista y de distanciarla de las formas comunes y generales que el siglo prescribe o propone; segundo, la obra pertenece al dominio del arte bajo la condición de que su raíz se sitúe en el modo de vida del artista; tercero, el arte deviene en una práctica ético - moral y política, en una actitud y un acto de críticos que inducen efectos contra-culturales al devolverle a la cultura su propia verdad desnuda.

En el siglo XIX, el arte es una práctica moderna del cinismo antiguo, tomando este bajo la perspectiva de categoría moral. Resuena la voz de Foucault cuando en su último curso plantea la posibilidad de hacer una historia del cinismo no como doctrina filosófica, sino como una actitud moral, como una disposición ético-moral que recorrería la historia de la cultura occidental bajo modos, principios y fines diversos; actitud moral amarrada a distintas formas de verdad; actitud moral comportada por diversos movimientos y militancias. La vida-artista es uno de esos medios (cf. Foucault, 2009, pp. 172-173).

En este trabajo se retoma la idea del cinismo como actitud, la cual hace del modo de vida una manifestación de la verdad que tiene el coraje de herir. Todo ello bajo la responsabilidad del estudio y con la pretensión de estudiar la vida de Flaubert respecto a la perspectiva ético-moral y política de la verdad estética. La pregunta «¿qué tipo de experiencia histórico-crítica de la vida conduce a Flaubert a hacer de su vida un testimonio visible de la verdad del arte $y$, a la vez, a la producción de una obra de arte de escritura que manifiesta la verdad de manera "horrible, cruel, desnuda"?» conduce las reflexiones e inflexiones contenidas en este libro. El propósito consiste en examinar el estilo de vida de Flaubert como el lugar visible de la verdad y como la caución de una obra de arte de escritura que, diciendo la verdad, ejerce una función eminentemente contra-cultural. 
Precisiones de método. Negativamente, la apuesta metodológica toma distancia de aquellos estudios adelantados bajo los signos de las ideologías y las representaciones de orden psicológico (tan comunes desde el siglo pasado). A título de ilustración, consideremos dos casos. El trabajo voluminoso de Sartre sobre Flaubert, El idiota de la familia, se despliega en dos órdenes. Por un lado, inscribe la vida y la obra del artista en una dimensión ideológica donde la imagen de clase social y sus representaciones son capitales; y por otro, la experiencia vivida por Flaubert se inscribe en la dimensión psicológica, donde resuena la muerte del padre, la sustitución, los complejos, entre otros. Sartre escribe, por ejemplo, «[...] en otros términos, la neurosis de Gustave es el Padre mismo, ese Otro Absoluto, ese Superyo instalado en él, que lo ha constituido en impotencia negativa [...]» (Sartre, 1988, II, p. 1893). El segundo, Bourdieu con su artículo La invención de la vida artista (1975), en el cual toma a Flaubert como referencia mayor del tema de la vida de artista, y deja sonar y resonar las nociones de ideología, alienación y conflictos de clase social. Positivamente, se parte de una apuesta, teórica y metodológica que consiste en mostrar mediante qué interferencias una serie de prácticas, a partir del momento en que son coordinadas con unos regímenes de verdad, han podido hacer que aquello que no existía, y que no existe en sí - vida-artistadevengue en algo que marca lo real, es decir, la vida de Flaubert.

Este trabajo se refiere en particular al discurso estético del siglo xIx, el cual fija la belleza como la verdad del arte; $y$ al discurso moral que fija la verdad en la vida. Una serie de cuestiones impone el pensamiento: ¿Qué experiencia hace Flaubert de sí mismo desde que descubre que, a propósito del arte y la moral, algo pasa por verdadero? ¿Cómo la relación que Flaubert establece consigo mismo y con los otros se encuentra afectada, modificada, transformada, por la existencia de discursos de verdad y por los efectos que inducen, por las obligaciones que imponen y por las promesas que formulan? ¿Qué es de Flaubert, qué debe hacer, 
cómo debe conducirse, si es verdadero que hay una verdad que le es dicha a través de aquello que lo lanza lo más lejos posible de la bêtise moderna de su siglo?

Indicados estos señalamientos, se induce fácilmente que el estudio corresponde al dominio filosófico $-\mathrm{y}$ no literario ni psicológico- - Sin embargo, no se trata de una reflexión filosófica sobre un literato, sino de una experiencia filosófica en la que se intenta desbrozar un modo de pensamiento inscrito bajo el signo de la estética del siglo XIX.

El ensayo de estudiar el estilo de vida de Flaubert como el lugar visible de la verdad y como la caución de una obra de arte de escritura que, diciendo la verdad, ejerce una función eminentemente contra-cultural, se despliega en cinco capítulos. El primer segmento precisa la idea de vida-artista y desbroza las preocupaciones de Flaubert que lo lanzan a la composición de un estilo de vida particular. En el segundo se ensaya desbrozar la noción de bêtise (estolidez o bestialidad) ${ }^{1}$ de Flaubert como operador estético-crítico de su vida-artista y de su obra. El tercero se enfoca en la cuestión de la búsqueda de un estilo de vida que procure, a través de la estética, lo que el estoicismo ha inventado para la moral: la tranquilidad. El cuarto apunta a examinar, por un lado, de qué manera los libros de Flaubert son una práctica de veridicción con función contra-cultural; y por otro, bajo qué condiciones su práctica de veridicción, al estar amarrada con su êthos, despliega el principio de impersonalidad del arte. El quinto indaga sobre la alethurgia de la bêtise - la manifestación visible de la bêtise en la vida - en La tentación de San Antonio, y los efectos

1 En el presente trabajo se usa - con reservas- el término francés bêtise bajo la acepción de bestialidad o estolidez. Se prefiere no traducirlo puesto que en el español no hay una palabra precisa para dar a entender dicho término, y más bajo los sentidos que le confiere Flaubert. Bêtise designa varias cosas, o mejor, envuelve el sentido de varias palabras tales como bestialidad, imbecilidad, estupidez, tontería, necedad y estulticia. Al respecto, Cámpora (2011) escribe: «[...] la palabra "bêtise" en francés es polisémica y gradual y parece no haber equivalencia en español que cubra la totalidad de acepciones. Esta situación adquiere proporciones considerables desde que se trata de traducir a Flaubert: en francés flaubertiano la palabra "bêtise" se extiende, como se sabe, sobre toda una gama de significados, y el sentido y el grado de matices que Flaubert le atribuye cambian incesantemente según el contexto» [Traducción propia] (p. 1). 
que induce en relación con un problema mayor del nihilismo del siglo XIX: si la verdad es des-realizada, si nada es verdadero, ¿cómo vivir, cómo conducir la vida? 



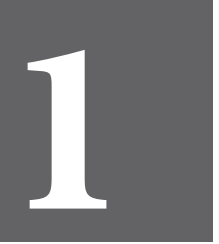

CAPÍTULO

UNO 



\section{Vida-artista}

«Todo depende de la meta que se quiera alcanzar. Un hombre que se ha constituido en artista ya no tiene el derecho de vivir como los otros» (Flaubert, 2007, p. 79). Esta idea de Flaubert, escrita cuando contaba con más de cincuenta y cuatro años, no emergió en la madurez de un hombre al que le restaban menos de cuatro años de melancolías y escrituras. Tres décadas antes había escrito a su amigo Vasse:

Para vivir, no digo feliz (esa meta es una ilusión funesta), sino tranquilo, hay que crearse afuera de la existencia visible, común y general a todos, otra existencia interna e inaccesible a lo que entra en el dominio de lo contingente, como dicen los filósofos (Flaubert, 1973, p. 271) ${ }^{2}$.

Entrecrucemos los dos fragmentos. El primero fija una idea directriz: la manera de vivir depende de la meta perseguida; el segundo dispone la tranquilidad como finalidad de la vida. El

2 Epístola enviada a E. Vasse el 4 de junio de 1846. 
primero fija una situación: quien se ha hecho artista no tiene derecho a vivir de manera común y ordinaria; el segundo pone la creación de una existencia otra, como medio para alcanzar la meta. Inferimos: en el pensamiento de Flaubert subyace la idea de un modo de vida particular y propio del artista, cuya diana no es la producción de una obra de escritura inscripta en la dinastía del arte, sino la tranquilad. La vida del artista se sitúa en una dimensión ética, en el dominio de un tipo de relación de sí consigo mismo y de sí con los otros. No sorprende el modo de vivir, distanciado de las maneras comunes y visibles, de un filósofo en la antigüedad, de un santo en la Edad Media, o de un bucanero en los tiempos modernos; pero, el hecho de que un discurso del arte, unas disposiciones estéticas y un saber-hacer específicos devengan, hace dos siglos, en un estilo de vida particular - $-\mathrm{y}$ de una élite de individuos-, es un acontecimiento inédito en la historia de la cultura occidental.

¿Qué designa la idea de vida-artista? ¿Qué denotación y connotación tiene el tema de vida-artista en el pensamiento de Flaubert? Construir respuestas posibles a estos interrogantes es el propósito de este capítulo. Una precisión es conveniente, se aborda la idea de vida-artista desde una perspectiva ética, al entender esta noción bajo el sentido de la relación que un individuo establece consigo y, a partir de ella, con los otros - aquí la noción de ética se aleja del enfoque democrático-normativo de la actualidad-. Flaubert emplea el término moral y no la palabra ética, sin embargo, dos acepciones se distinguen en su uso; por una parte, usa una noción de moral la cual podría decirse que es de vocación ética; $y$, por otra, con moral designa el régimen social, jurídico y político de las conductas. Metodológicamente, es necesario distanciarse de la plétora de estudios sobre Flaubert adelantados en órdenes psicológicos, psicoanalíticos o ideológicos; y, además, considerar con prevención los rumores, las formulaciones y los clichés que circulan, sobre la vida del artista, en los discursos desde el siglo XIx hasta la actualidad. 


\subsection{La idea de vida-artista}

Un murmullo nuevo recorre los discursos del arte a principios del siglo xIx: vida de artista. Con una prehistoria muy reciente, la demiurgia del arte moderno fabrica la idea de vida-artista o vida de artista. Esta idea, extraña en otros siglos, designa dos cosas: la idea de que la meta elevada del arte es la creación de un estilo de existencia la cual procura al artista un modo de vida sui generis y la idea de que la obra de arte está en relación con la forma de vida del artista. El arte alcanza su dimensión real en la forma y conducción reflexiva de la vida, en un modo de existencia diferenciado de los lotes de vida comunes y generales promocionados o prescritos por la cultura. Los primeros esbozos de esta idea parecen ser lanzados por Diderot en El Sobrino de Rameau, donde articula, de manera muy particular, las relaciones entre arte y modo de vivir; y en el Salón de 1767, en el que con ironía manifiesta:

Lanzarse a los extremos, he aquí la regla del poeta. Guardar un justo medio en todo, he aquí la regla de la felicidad. No hay que hacer en absoluto poesía en la vida. Los héroes, los amantes románticos, los grandes patriotas, los magistrados inflexibles, los apóstoles de la religión, los filósofos a ultranza, todos esos raros y divinos insensatos hacen poesía en la vida, de ahí su desgracia. Son ellos que, después de su muerte, proporcionan los grandes cuadros. Son excelentes en pintura. Es por experiencia que la naturaleza condena a la desgracia a aquél que ha abandonado al genio, y a aquella que ha dotado de belleza; esos son seres poéticos [...]. Yo hago en mí mismo elogio de la mediocridad que pone igualmente al abrigo de la culpa y del querer; y me pregunto por qué, no obstante, nadie querría perder su sensibilidad, y devenir mediocre. ¡Oh vanidad del hombre! (Diderot, 1818, p. 270).

La prehistoria de la idea de vida-artista no cuenta con más de medio siglo. En 1550, Giorgio Vasari publica Las vidas de los más excelentes pintores, escultores y arquitectos italianos, de Cimabue hasta nuestro tiempo, mas esta obra no accede a dicha idea. Inspirado en Diógenes Laercio, Vasari se ocupa más 
de la vida de los artistas que de sus obras; pero su enfoque es patético-biográfico o anecdótico, se ocupa de gustos, caprichos, pasiones, peripecias, de la recolección de datos, de leyendas y de curiosidades de las vidas de sus héroes. De igual manera, procede Benvenuto Cellini en su Autobiografía. La idea de vida-artista irrumpe inmediatamente después de la fabricación de las nociones de artista y de estética, perfiladas en el transcurso de la segunda mitad del siglo XVIII. La palabra artista (aún hoy desbordante y brumosa) se remonta al siglo XVI, tiempos en los que era más o menos sinónimo de hombre de oficio, designaba un individuo que disponía de un saber-hacer sin diferenciar los dominios de cosas en los cuales ejercía su competencia. En la segunda mitad del siglo XVIII, ese saber-hacer se tipificó en tres dominios: artes técnicas, artes liberales y bellas artes. Cuando aparece el campo de estas últimas, la noción de artista - más o menos como se conoce hoy- encuentra propiamente su lugar. La figura de artista queda diferenciada de quienes practican la relojería, las artes mecánicas, la peluquería, entre otras. En los procesos de configuración del domino de las bellas artes y de la figura artista, los discursos empiezan a relacionar el arte y la vida. A partir de esta relación, se produce rápidamente la noción de estética en el contexto alemán. El romanticismo, articulando las nociones de arte, estética, vida y artista, inventa la idea de vida-artista.

La vida-artista comporta, por divisa y por consigna, la construcción individual de una estética de la vida. ¡Poetizar la vida! ¡Vivir la poesía! Esta idea está presente en el romanticismo alemán, particularmente en Friedrich Schlegel. Así, a partir del mencionado romanticismo y de Byron, el régimen estético convoca a un arte de vivir, a vivir la belleza de la poesía, a poetizar la vida. Envuelta en la belleza, y en su individualidad, la vida deviene en la carne de la estética. Importada, la idea de vidaartista entra rápidamente en Francia, se constituye en tema y en modo de subjetivación que, bajo diferentes formas, transita en toda la longitud del siglo xıx. El misticismo estético de Flaubert y el dandismo de Baudelaire o Huysmans, las escandalosas maneras 
de Manet o la críptica vida de Van Gogh; e inclusive la bohemia de proletarios, burgueses, agitadores profesionales y aficionados esnobistas, son variaciones - graves o leves- del mismo tema. Muy esquemáticamente - con reservas y a título de ilustración-, se puede considerar algunos momentos del periplo de la idea de vida-artista en Francia. En las primeras décadas del siglo XIX, madame Steäl abre el acceso a Hegel y al romanticismo alemán mientras, paralelamente, Byron deviene en la mayor referencia poética y existencial para los franceses. Difuso, confuso, profuso, el naciente romanticismo apostó su cuerpo y su espíritu en una estética marcada por la melancolía y el distanciamiento del mundo prosaico, la crítica y la creación de la belleza; caracteres que no escapan a la mirada sospechosa de Hegel. En sus objeciones a la ironía de Schlegel, a esa "genial ironía divina» que, como concentración del yo en sí mismo, borra la eticidad, dicho autor escribe:

De cara a lo bello y al arte, lo dicho recibe el sentido de vivir como artista y de configurar la propia vida artísticamente. Y yo vivo como artista, de acuerdo con este principio, cuando toda mi acción y exteriorización en general, en tanto afecta a un contenido, permanece mera apariencia para mí y asume una forma que se halla enteramente en mi poder [...]. En aquella posición donde el yo que lo pone y disuelve todo desde sí es el artista, a cuya conciencia ningún contenido se presenta como absoluto, como válido en y para sí, pues todo contenido se ofrece como aniquilable apariencia puesta por uno mismo, no hay lugar alguno para la mencionada seriedad, puesto que sólo [sic] se atribuye validez al formalismo del yo [...]. Este virtuosismo de una vida irónico-artística se aprehende a sí mismo como una genialidad divina, para la cual todas y cada una de las cosas es tan sólo [sic] una criatura sin esencia [...]. Quien se halla en ese punto de vista de una genialidad divina, mira a los demás hombres desde arriba, y éstos [sic] se presentan para él como limitados y vulgares [...]. Así-, el individuo que vive como artista, ciertamente entra en relaciones con los demás, vive con amigos, personas amadas, etc. $[s i c]$, pero, como genio, tiene por nula esta relación con una 
realidad determinada, con acciones especiales, así- como con lo universal en y para sí, y se comporta irónicamente frente a esto (Hegel, 1989, pp. 58-59).

En 1834, G. Sand (1966) escribe a Musset:

No estás destinado a arrastrarte sobre el lodo de la realidad. Tú estás hecho para crear tú mismo tu realidad en un mundo más elevado [...] espera que tu vida sea un poema tan bello como aquellos que ha soñado tu inteligencia (p. 625) ${ }^{3}$.

En el mismo año, E. Quinet (1834) escribe a propósito del modo de vida de Chateaubriand, atestado en Memorias de ultratumba:

Esta vida de poeta es ella misma un poema. Si le hubieran dado a usted elegir los eventos a su gusto, no los había entrelazado y mezclado tan bien [...]. Usted toca a la vez dos mundos, aquel de la fantasía y aquel de la realidad [...]. Usted toca a la puerta de los sueños, y es la vida que abre. Usted entra en la vida, y es el sueño que reaparece todavía (p. 205).

Dos años después, Chateaubriand (1836) saluda a Milton al decir: “"el poeta debe ser un verdadero poema”, ough to be himself a true poem, es decir, un modelo de las mejores y más honorables cosas» (p. 99). En suma, ahí se trata no de la producción de obras exteriores a la existencia misma, sino de ser y hacer vida de artista, tal como lo manifiesta Jules Janin en el texto editorial del primer número de la revista L'Artiste (como se citó en Díaz, 2015, p. 34). Los clichés de la época comportan de alguna manera la idea de la singularidad de la vida-artista: "capricho de artista», «locura de artista», "pasión de artista», "dolor de artista», "gusto de artista», «vida intensa», «vida de pasión», «vida de azar», «vida agitada y original», «vida de ilusiones y sueños», o una «vida de delicias». En un segundo momento, con el correr de los años cuarenta, nuevas connotaciones se adicionaron a la vida-artista. Más que ver el mundo a través del prisma de una obra, y hacer de 3 Epístola a Musset del 15 de junio de 1834. 
esa mirada la forma de una existencia singular, en dicho aspecto subyacía una actitud contra-cultural la cual se expresaba en la crítica y la descalificación de instituciones, regímenes morales, reglas sociales, cánones artísticos, entre otros elementos. El artista hacía de su existencia y de su obra el teatro escandaloso de la verdad. La vida bohemia realizaba de la transgresión su visibilidad. El tema de la vida-artista se difundía masivamente en círculos intelectuales y artísticos, en periódicos y revistas. No obstante, la plasticidad del tema no lo protegía ni de la banalidad ni del cliché. En 1843, E. Monnais, en su libro titulado Esbozos de la vida de artista (publicado bajo el seudónimo de Paul Smith), definía los rasgos y las maneras que hacían de un individuo un artista; en ellas tenía en cuenta sus vestimentas, sus cabellos, sus relaciones sexuales, su soltería y matrimonio, sus finanzas, entre otros componentes (cf. Smith, 1844). Y el periódico Figaro (desde 1833) publicaba burlas sobre el estereotipo del artista:

[...] el arte reina sobre todas las conciencias como el propietario sobre los apartamentos [...]. Todos hablan de arte, pero los más intrépidos, los más divertidos mitificadores solo se aventuran a apropiarse el epíteto de artista [...]. Él habla de sus amantes, de sus victorias, de sus duelos, de sus aventuras de soltero, y termina siempre afirmando que eso es una vida de artista, un capricho de artista, una locura de artista, una pasión de artista, un dolor de artista, y un gusto de artista. Ordinariamente porta la barba a lo Henri III, los cabellos a la Rafael, el chaleco a la Robespierre, el cuello a la Lord Byron, el pantalón a la Tizino [...]. Frecuentemente, dice proletario por pobre, guarda burgués por guardia nacional [...] flânerie por paseo, progresividad por progreso (como se citó en Díaz, 2015, p. 74).

En la segunda mitad del siglo XIX, frente a las tendencias románticas de la vida de artista, y según la manera de Musset o Víctor Hugo, emergieron otras formas, por ejemplo, el flâneur y el dandi - quien hace de la modernidad estética una ascesis, una especie de religión-. En ellas la transformación relevante es el advenimiento de una distancia entre la composición de la obra y 
la biografía del autor; idea de la «despersonalización» de la obra de arte, la cual se difunde en casos como el de Flaubert, Gautier, los hermanos Goncourt, Maupassant, Baudelaire, entre otros. El autor no se escribe en su obra; no obstante, la forma de vida se instaura en la fuente de donde emana la misma. Así, la vida-artista es una forma de existencia la cual rebasa la producción de la obra, y en la que la composición de aquella es una especie de modo en el que se expresa ella misma. Sin embargo, ¿qué designa el sintagma vida-artista? ¿Qué sentido tiene el sintagma forma de vida-artista?

\subsection{Forma de vida}

Hoy, el término vida nos lanza a un dominio biológico, a un objeto epistemológico, a una dimensión política. También se emplea con frecuencia el término existencia para referirse a las maneras de vivir de los hombres. Los modos de vida no están escindidos de las relaciones que marcan y las cargas que admite el discurso contemporáneo de la vida ni tampoco de las tecnologías ni del gobierno de las conductas; las maneras de vivir no se salvan de la gravedad biopolítica. ¿Qué es la existencia? La forma de vida es la existencia misma de un ser humano y no una vida desnuda ${ }^{4}$; no es una cosa que exista substancialmente en sí misma, no es algo que esté ahí - en alguna parte- como materia primera, muda, quieta y sin manera esperando recibir una forma determinada. La vida es inseparable de sus maneras, de sus accidentes, de sus contingencias, del bienestar y del sufrimiento; la vida es inseparable de las peripecias que pueden revertirla del bienestar a la desgracia, es inherente a su devenir constante y a la posibilidad de su transformación ${ }^{5}$.

4 La noción de vida biológica es abstracta, pobre y casi vacía; es una noción que casi no dice nada ni lleva a ninguna parte en las reflexiones. Escribe Agamben (2002):

[...] desde un punto de vista estrictamente científico, el concepto de vida no tiene ningún sentido: "las discusiones sobre la significación real de las palabras vida y muerte —escribe Medawar [biólogo inglés] — son los índices, en biología, de una conversación de bajo nivel. Estas palabras no tienen ninguna significación intrínseca que pudiera ser esclarecida por un estudio atento y más profundo (p. 18).

5 Agamben (2002), al seguir la traza de Foucault, entiende por forma de vida una vida que no puede ser separada jamás de su forma, una vida de la cual no es posible, en absoluto jamás separar algo como una vida desnuda. 
Los griegos disponían de dos palabras distintas para designar la vida: zoê, término que designaba la vida en cuanto cualidad de ser viviente compartida por los dioses, los animales y los hombres; y el término bios que designaba la vida de los hombres, aquella vida frágil inestable sometida a las contingencias, aquella vida susceptible de transformaciones, aquella vida que podría ser la materia de una transformación reflexiva y que, conducida por el pensamiento, podría llegar a alcanzar una forma admirable, memorable y verdadera o, también ser la materia de la estulticia y las pasiones.

El modo de ser de un hombre, su forma de vida, no es más, no es menos que su êthos o su subjetividad. Empleando los términos forma de vida, maneras de vivir, êthos, modo de ser y subjetividad bajo el mismo sentido, en este estudio se considera la noción de subjetividad no como una identidad psicológica ni una conciencia de sí del individuo ni una interioridad; la subjetividad no es una cosa en sí ni por sí; no es algo con su propia naturaleza, con sus propios deseos, con sus derechos y su libertad; ni un algo dado sobre el que vendrían a depositarse obligaciones, constricciones, represiones, alienaciones; ni la soberanía de un «yo». La subjetividad se toma como la manera de un tipo de experiencia que un ser humano hace sobre sí mismo y la experiencia de sí no es otra cosa que las relaciones de sí consigo mismo.

Foucault (2001c), al hablar del concepto de subjetividad, señala que es «[...] la manera mediante la cual el sujeto hace [de] la experiencia de sí mismo [...] un juego donde él tiene una relación consigo» (p. 1452); modo de un tipo de experiencia que un ser humano hace de sí mismo en cuanto comporta la forma de sujeto de tal. El sí mismo se define, a su vez, por las relaciones de sí consigo mismo; por consiguiente, «[...] es la relación con sí que constituye [la subjetividad]» (Foucault, 2015, p. 178). De esta forma, otro apartado del mismo texto dice lo siguiente: 
El sí no es otra cosa que las relaciones con sí [consigo mismo]. El sí es una relación. El sí no es una realidad, no es alguna cosa estructurada que está dada desde el comienzo. Es una relación con sí. Yo creo que es imposible dar del sí otra definición que esta relación y este conjunto de relaciones (p. 117).

La expresión «el sí no es otra cosa que la relación con sí mismo» parece una tautología, mas se trata de una adecuación ontológica de la relación de sí con sí mismo, el sí mismo es inmanente a la relación con sí mismo. De esta manera, expresa Foucault (2017): «[...] el sí no es nada más, nada menos que la relación que nosotros tenemos con nosotros mismos, el estatuto ontológico de sí no es otra cosa que la relación que nosotros con nosotros mismos» (p. 285). Así, en el dosier Culture de soi, según Gros se lee lo siguiente: «[...] el sí con el cual uno tiene relación no es otra cosa que la relación misma [...] es en suma la inmanencia, o mejor la adecuación ontológica del sí con la relación» (como se citó en Foucault, 2001a, p. 514). La relación de sí con sí mismo se instaura en cuanto el individuo, bajo la forma sujeto, se inscribe en un dominio determinado de cosas. Al entrar en relación con ellas, el individuo instaura una relación consigo mismo, lo cual constituye el sí mismo. La relación que se establece consigo mismo es indisociable de la forma de sujeto de tal o cual cosa. Al respecto Foucault (2013) dice:

[...] por sí entiendo el tipo de relación que un ser humano en tanto que sujeto puede tener y sostener consigo mismo. Por ejemplo, el ser humano puede ser un sujeto político en la ciudad. "Sujeto político" quiere decir que puede votar, o que puede ser explotado por los otros, etc. El sí mismo sería el tipo de relación que ese ser humano, en cuanto sujeto, tiene consigo en una relación política [...] (p. 131).

Algunas precisiones no carecen de pertinencia. El sujeto 
[...] es una forma, y esta forma no es sobre todo ni siempre idéntica a ella misma. [Por tanto, u]sted no tiene con usted mismo el mismo tipo de relaciones cuando usted se constituye en sujeto político [...] que cuando usted busca realizar su deseo en una relación sexual [...]. En cada caso, uno juega, uno establece consigo mismo formas de relación diferentes (Foucault, 2001b, pp. 1537-1538).

Sujeto es el nombre de unas series complejas de relaciones que constituyen ciertas formas que toma el ser humano en cuanto actúa inscripto en un dominio determinado de cosas. El ser humano, sin sus formas de sujeto, es un nominalismo, algo vacío, inexistente e impensable. Concebir una persona sin formas de sujeto, sería como imaginar un ser humano sin acciones, sin pensamiento, sin afectos, sin cultura ni sociedad; y al pensamiento repugna pensar tal bestia virtual. En la historia se producen constantemente formas de sujeto desiguales; las cuales se fundan, se refundan y se transforman. Por ejemplo, puesto un tipo de verdad, se instituye al individuo en sujeto de conocimiento; puestas unas matrices de comportamiento, se instituye al individuo en sujeto político o jurídico. Mas, en un ser humano coexisten tantas y diversas formas de sujeto como dominios de cosas en los cuales juegan sus roles. El ser humano como sujeto puede ser, por ejemplo, sujeto de conocimiento en el dominio de la física, sujeto político en el Estado o sujeto de deseo con su pareja. En el caso de la subjetividad se encuentra que puestas (propuestas o prescritas) unas formas de subjetividad en la cultura, el ser humano se instituye en en sujeto ético. El sujeto de la relación con sí, la forma de sujeto puesta en juego en la subjetividad, se constituye en un sujeto ético. La instauración del individuo como sujeto, mediante la el establecimiento de la subjetividad, es una práctica de sí o un trabajo de sí, pues los sujetos y los objetos son producidos no solamente por un juego de lenguaje, sino por las prácticas. Por tanto, Foucault (2015) dice: 
Uno se constituye como sujeto en la relación con sí, el sujeto no es dado. Es la relación con sí que constituye [la subjetividad] [...] el sujeto se constituye en prácticas reales, en prácticas históricamente analizables. Y hay una tecnología de la constitución del sujeto que, utilizándolos, atraviesa los sistemas simbólicos, pero no es simplemente por el juego de sistemas simbólicos que el sujeto se constituye (p. 178).

Ahora bien, si el sí es la relación de uno consigo mismo - en cuanto está inscrito en un dominio determinado de cosas-, se puede considerar que esa relación no es otra cosa que el uso de sí mismo con tal de despojar el término uso de su carga instrumental, tal como lo plantea Agamben (cf. 2017, p. 78) cuando indica que el sí mismo es el uso propio de la relación de sí con sí mismo. De este modo, el ser del sí mismo es, y solo es, uso de las relaciones que la persona instaura con sí misma; y el sí mismo se constituye y se define como esas relaciones de sí con sí siempre en uso, el sí mismo es el ser-en-uso, el «usante» de sí.

Así como el sujeto no es, para Foucault, sustancia, sino proceso, del mismo modo la dimensión ética —el cuidado de sí- no posee una sustancia autónoma: no tiene otro lugar y otra consistencia más que la relación de uso entre el hombre y el mundo. El cuidado de sí presupone la chrêsis y el sí mismo que nombra el sujeto ético no es algo distinto respecto del sujeto de uso, sino que permanece inmanente a este [...] (Agamben, 2017, p. 78).

Si el sí con el cual tiene relación cada individuo, es la adecuación ontológica de sí a dicha vinculación, se puede considerar que el sí mismo no es otra cosa que la adecuación ontológica de sí al uso de sí mismo, porque «El sí mismo no es otra cosa que el uso de sí»(Agamben, 2017, p. 116), lo que significa que el individuo se afecta y se constituye en la medida en que está en relación con algo. Desbrozando la noción de sí mismo a partir del término griego de chrêsis, Agamben compone su concepto de uso. El verbo chrêssthai no tiene un significado propio, pues adquiere acepciones distintas según los contextos en los cuales se 
emplea; este extrae su significación según la connotación que lo acompaña. Por ejemplo, chresthaithéoi o «usar del Dios» designa consultar un oráculo; chresthainostôิ o «usar del retorno» denota experimentar nostalgia. Dicho verbo no significa lo mismo que la expresión moderna «usar» - servirse de... o utilizar algo como instrumento- (Agamben, 2017).

Agamben (2017) retoma una tesis de Benveniste en la cual se considera que los verbos griegos, llamados mediales, no son ni activos ni pasivos. Los primeros denotan un proceso que se realiza a partir del sujeto y por fuera de él; mientras que, en un verbo medio como tal, el proceso tiene lugar en el sujeto mismo - el sujeto es interior al proceso-, donde

Por una parte, el sujeto que realiza la acción, por el hecho mismo de realizarla, no actúa transitivamente sobre un objeto, sino que se implica y se afecta ante todo a sí mismo en el proceso; [y] por la otra, precisamente por esto, el proceso supone una topología singular, en la que el objeto no supera la acción, sino que es él mismo el lugar de su suceder (Agamben, 2017, pp. 69-70).

Allí, se presenta una zona de indeterminación entre el sujeto y el objeto, el agente es el lugar de la acción y, de alguna manera, también el objeto. Entre el activo y el pasivo, aquel recibe una afección de su propia acción. Precisamente, para Agamben (2017), el verbo chrêssthai «[...] expresa la relación que se tiene consigo, la afección que se recibe en cuanto se está en relación con un determinado ente» (p. 70); así como en la experiencia de hacer visita, cuando el sujeto se constituye en visitante, se pasea a sí mismo y hace experiencia de sí en cuanto paseante; porque

[...] de la misma manera todo uso es, ante todo, uso de sí mismo [...] [y como bien lo indica el mismo autor según su experiencia], para entrar en relación de uso con algo, debo ser afectado por ese algo, constituirme a mí mismo como aquel que hace uso de ese algo. El hombre y el mundo están, en el uso, en una relación de 
absoluta y recíproca inmanencia; en el usar algo, se trata, ante todo, del ser del propio usante (Agamben, 2017, p. 72).

Si en el acto de visitar bajo su diátesis activa, lo esencial es la acción del agente por fuera de sí; en el caso del uso, lo fundamental es constituirse en visitante; es la afección que el agente usante recibe y no la acción que efectúa; y otro tanto acece bajo la diátesis pasiva.

A la afección que el agente recibe de su acción corresponde la afección que el paciente recibe de su pasión. El sujeto y el objeto son así desactivados y vueltos inoperosos y, en su lugar, les sucede el uso como una nueva figura de la praxis humana (Agamben, 2017, p. 73).

Para Agamben (2017), la abolición radical del sujeto está en relación directa con el uso de sí; puesto que dicho concepto borra la distinción entre el ser y el tener. Contra la tradición del aristotelismo, el cual culmina en la escolástica; por una parte, concibe el ser-en-uso como algo distinto al ser-en-acto; y por la otra, sitúa el ser-en-uso en la dimensión del hábito, como disposición, héxis. El hábito «[...] en cuanto se da como uso habitual y está, por consiguiente, siempre ya en uso, no presupone una potencia que deba, en un determinado momento, pasar al acto, ponerse en obra» (p. 121). Al sustituir el ser-en-acto por el ser-en-uso, se desactiva el dispositivo potencia-acto y, a la vez, el hábito - el cual había sido concebido por Aristóteles en función de precisar y sostener la dynamis como tal- pierde toda connotación de potencia. El ser-en-uso no es otra cosa que el uso del hábito, el uso habitual del hábito, la condición habitual del hábito. Esta concepción

[...] implica una neutralización de la oposición sujeto/objeto, entonces aquí no hay sitio para un sujeto propietario del hábito, que pueda decidir ponerlo o no ponerlo en obra. El sí mismo, que se constituye en la relación de uso, no es un sujeto, no es otra cosa que esta relación (Agamben, 2017, p. 124). 
Apoyándose en los estudios de la lingüística de Benveniste sobre la relación del «ser» y del «tener», Agamben va más allá. Contra Aristóteles, considera la héxis y no el hábito como algo que pertenece a un sujeto, pues este último se sitúa más adelante tanto del ser como del tener, puesto «[...] el uso rompe la ambigua implicación de ser y tener que define la ontología aristotélica [...] El uso, como el hábito, es una forma-de-vida y no el saber o la facultad de un sujeto» (Agamben, 2017, p. 127). No hay un sujeto dado de antemano, la subjetividad no es una substancia ni tampoco el resultado objetivable de un proceso; la relación consigo mismo es la misma operación, el mismo proceso en el cual se constituye el sujeto. La subjetividad se constituye por la relación de sí consigo mismo, y es ahí, en ese mismo proceso, que el individuo se instituye en sujeto de tal o cual cosa en un dominio determinado de prácticas, instauradas y agenciadas por dispositivos culturales.

Así, el sujeto es tan inseparable de la subjetividad como la subjetividad es inconcebible sin la forma sujeto. Tanto el uno como la otra se constituyen en prácticas determinadas, y no de manera abstracta, ni en una generalidad inespecífica. Constituidos los dos no permanecen en potencia esperando su pasaje posible al acto; concomitante con su constitución es su uso constitutivo de actos o prácticas. Es decir, el sujeto y la subjetividad — que le es inmanente- están siempre en uso, simultáneamente a su constitución. La subjetividad es lo que le sucede a un individuo en la medida en que se acontece a sí mismo, a saber: el uso de la relación de sí con sí mismo, el uso de la relación que se relaciona consigo misma. Esta relación no se atribuye a la voluntad de un sujeto soberano, de alguna manera, es una especie de relación derivada de los tipos de subjetivación propuestos o prescritos por los dispositivos de cada época, sin que esto implique que sea su duplicación. Por lo tanto, la relación de sí al relacionarse consigo misma, se relaciona eo ipso con los dispositivos de las formaciones históricas. 
La relación de sí con sí mismo es una adecuación ontológica la cual constituye el sí instaurándose en disposición, héxis y hábitos siempre en uso. Así, cuando se habla de estos últimos, de tal o cual individuo, la referencia dice de las disposiciones, y de ellos mismos que no son otra cosa que la subjetividad, la existencia, o la forma de vida del individuo. De esta manera, se puede decir que estilo de vida o forma de vida designa la subjetividad de un ser humano, el sí mismo del individuo o la relación de sí consigo mismo; siempre en uso y nunca en potencia. La forma de vida es el uso habitual de sí mismo, es decir, el uso de las propias disposiciones, hábitos, los cuales son inmanentes a la relación que instaura consigo mismo en cuanto está inscripto en un dominio determinado de cosas.

El uso de sí o la subjetividad no es un «afuera» de las formas de vida prescritas o propuestas en las formaciones históricas de la cultura, se trata de una especie de pliegue interior del exterior que, en su uso, adquiere características particulares en los entrecruzamientos de relaciones múltiples de diferente naturaleza-. Desde el alba de Occidente hasta el presente que nos constituye, las diversas maneras de vivir de los hombres se han relacionado con diferentes modos de producción o manifestación de la verdad en la cultura. La forma de vida que comporta la vidaartista es una declinación de la verdadera vida. En el uso de la propia vida se procura una forma emanada de la verdad del arte. La vida del artista es el uso de sí mismo inscripto bajo el signo del arte en su verdad. El estatuto del artista no es definido por una función social o por una partición profesional, sino por su carácter ético-moral. La vida-artista no es tampoco una creación de un sujeto el cual pudiera ser separado en una originaria posición constituyente. No se trata de un sujeto que ligue su actividad creadora a la relación que él mantiene consigo mismo, sino que el artista liga esa la relación consigo mismo a una actividad creadora (Foucault, como se citó en Agamben, 2016). 
De este modo, la relación de sí consigo mismo es, en su constitución propia, creación y actividad en la que no hay un sujeto situado en una posición exterior a ese proceso. Ligado el uso de sí mismo a la actividad creadora, el estilo de vida-artista no puede, en ningún caso, reducirse $\mathrm{u}$ homologarse a las maneras de vivir visibles, comunes y generales de los hombres ni a los regímenes y valores ordinarios de la sociedad. Más que ser el creador una obra original en dominio de las cosas de arte, el artista «[...] es primeramente un héroe legendario, símbolo de un arte de vivir tenido por modelo. Lo importante para él no es tanto crear como artista, sino vivir como tal: hacer de su vida una obra de arte. “ $i S e r$ artista!” (Díaz, 2015, p. 33). Ser artista no es otra cosa que el uso de sí mismo de manera muy particular.

En la historia de la cultura occidental -en el siglo XIX-, irrumpe un nuevo episodio del heroísmo de la vida: el artista entra en escena cuando, al mismo tiempo, el filósofo sale para convertirse en funcionario público. El artista es el vehículo moderno de la figura legendaria del héroe de la vida -el sabio, el filósofo, el profeta, el eremita, el santo-; y es entendido como una figura histórica, un personaje cultural que lleva al límite extremo la conducción reflexiva de su propia existencia, haciéndola su razón de ser. Dicha conducción no es otra cosa que el uso extremo de la verdad en la vida; dado que esta deviene en el lugar visible de la verdad, en una ética de la verdad. En la vida-artista, la verdadera vida y la verdad el arte se indeterminan, entran en una zona de indiferenciación. Por tanto, si ética es

[...] el modo en cual cada quien entra en contacto consigo mismo, entonces la práctica artística [...] pertenece ante todo a la ética y no a la estética, es esencialmente uso de sí. En el instante en el que se constituye como forma-de-vida, el artista ya no es el autor (en el sentido moderno, esencialmente jurídico, del término) de la obra ni el propietario de la operación creativa. Estos son únicamente algo así como los restos subjetivos y las hipóstasis que resultan de la constitución de la forma de vida (Agamben, 2017, p. 441). 
La idea de vida-artista se hace real al devenir en uso de sí mismo. La disposición (hábito) del artista en uso no es otra cosa que su forma de vida. Hay un rasgo más, y propio: la crítica. Por consiguiente, esta forma de vida es crítica, testimonio y teatro visible de un escándalo de la verdad. En la forma de vida-artista, la crítica no es una función agregada, sino una actitud, un hábito en uso inseparable de la forma de vida; dado que ella, en su propio uso, en materialidad de vida, deviene en una crítica moral permanente de la cultura. Así, la vida del artista es una manifestación contracultural, una crítica visible que comporta el riesgo de herir con su propia verdad $^{6}$. En su propia existencia, el artista desenmascara la vida, la pone al desnudo, la reduce a su extrema elementalidad; hace de ella la expresión visible de aquello que, en la cultura, no tiene el derecho o la posibilidad de expresarse.

\subsection{Gustave Flaubert en su «triste boutique»}

«La existencia en ella misma [...] la vida humana es una triste boutique, decididamente, una cosa fea, engorrosa y complicada. El Arte no tiene otro propósito, para la gente de espíritu, que escamotear el fardo y la amargura» (Flaubert, 1991, p. 400) ${ }^{7}$. Para responder a la inquietante melancolía de su amiga Amélie Bosquet, Flaubert expresa dos pensamientos que, desde su juventud hasta su muerte, lo han habitado permanentemente: el tedium vitae que emerge del fango de la vida humana y el arte como salvación. Estos dos pensamientos son inmanentes a dos disposiciones graves que se entre-tienen y se reforzaban. Por un lado, un hábito melancólico, y por otro, un hábito estético. La relación de sí consigo mismo, uso de sí, o forma de vida de Flaubert se sitúa en la tensión constante de

\footnotetext{
6 La actitud crítica, o uso crítico de la vida, se inscribe a partir del siglo v a. C. - cuando irrumpe la filosofía - en la milenaria historia de las formas de vida — al lado de las formas comúnmente extendidas-; ha tenido su espacio un modo de vida que hace de la vida misma el testimonio riguroso y crítico de la verdad. Se trata de un tipo de vida que, por una parte, se reconoce como verdadera vida, una vida en la verdad para la verdad; y por otra, como un tipo de vida que, distanciándose de las maneras comunes, hace de ellas el blanco de una crítica encarnada y manifestada en la propia existencia; por ejemplo, la vida de Sócrates, de los cínicos, de los eremitas, de los místicos. La vida como el teatro visible y escandaloso de la verdad.

7 Epístola enviada a A. Bosquet el 19 de julio de 1864.
} 
la potencia de la melancolía con la potencia de la belleza inscripta en el arte. Cuando apenas contaba con un poco menos de trece años, reflexionaba sobre sus disposiciones mayores:

[...] si no hubiera tenido en la cabeza y en la punta de mi pluma una reina de Francia del siglo quince, estaría totalmente disgustado de la vida y haría mucho tiempo que una bala me habría liberado de esta broma bufonesca que se llama vida (Flaubert, 1973, p. 15).

$\mathrm{Su}$ sensibilidad fina y su pensamiento agudo hacen insoportable la agitación, la confusión, la bêtise moderna de las maneras de vivir visibles, comunes y generales. Por consiguiente, inventar una forma de vida otra fue una necesidad de Flaubert. Y, ahí, el arte pone en juego sus bondades creando los medios para eludir el fardo de la amargura y la levedad de la vida. Aquella idea de la realización plena del arte en la vida es apropiada radicalmente por Flaubert. Ética del arte.

La melancolía y la estética, con sus sendos pensamientos, irrumpen muy temprano en la vida de Flaubert, varias de sus experiencias infantiles dan testimonio. Cuando cuenta con un poco menos de treinta y dos años, narra a Colet ciertas experiencias que pueden ser consideradas como el punto de emergencia de sus afecciones o disposiciones mayores. Al tener tan solo seis o siete años vio, por primera vez, los locos en el hospicio general donde «[... en las celdas, sentadas y atadas por la mitad del cuerpo, desnudas hasta la cintura y todas despeinadas, una docena de mujeres gritaban y se arrancaban la cara con las uñas» (Flaubert, 1980, p. 376) ${ }^{8}$. Así, otra experiencia del mismo género y de la misma época, tiene que ver con el anfiteatro del hospital donde trabajaba su padre; el cual estaba contiguo al jardín de su casa. Muchas veces con su hermana escalaban la reja y se situaban entre las vides; desde ahí, veían claramente los cadáveres extendidos, mientras las moscas, zumbando y revoloteando sobre las flores y sobre ellos, iban a posarse en los muertos. Según esto, Flaubert

8 Epístola enviada a L. Colet el 7 de julio de 1853. 
(1980) expresa: «Estas son buenas impresiones para tener siendo joven; ellas virilizan. ¡Qué extraños recuerdos tengo en este género!» (p. 376). Sin duda, se trata de una clase de impresiones que, en el siglo XIx - en particular-, constituyen un topos en la melancolía y en el arte. De este modo, las percepciones de las miserias humanas, Flaubert las reflexiona a partir de sus lecturas, las repasa intensamente y les pone el toque de ironía negra; por ejemplo, al ver el cadáver de su hermana y recordar el de su padre, escribe:

¡Cómo he pensado en todo aquello, durante dos noches, en la velación de esa pobre y querida hermosa niña! Yo veo aún a mi padre levantando la cabeza de su disección y diciéndonos que nos fuéramos. Otro cadáver también, él. [...] ¡Cuántos dramas feroces he construido en la Morgue, donde antes tenía la furia de ir, etc. [sic]! Creo, además, que en este lugar tengo una facultad de percepción particular; de hecho, malsana, yo me conozco (p. 376).

Esas experiencias infantiles indujeron percepciones, afectos y hábitos. Y esa «facultad de percepción particular» tradujo su propia potencia. Se han construido dramas feroces sobre la vida humana, se han levantado aires fúnebres y cínicos, ha desaparecido el amor a la vida y el miedo a la muerte, y las impresiones dotaron de coraje la existencia de Flaubert. Este tipo de experiencias de sí consigo mismo, son sostenidas hasta devenir en disposiciones:

Sin cesar, la antítesis se levanta frente a mis ojos. Yo no he visto jamás un niño sin pensar que él devendrá viejo, ni en una cuna sin soñar en una tumba. La contemplación de una mujer desnuda me hace soñar en su esqueleto. Eso hace que los espectáculos alegres me vuelvan triste, y que los espectáculos tristes me afecten poco. Yo lloro mucho adentro para verter lágrimas afuera; una lectura me mueve más que un mal real (Flaubert, 1973, p. 275) ${ }^{9}$.

La reflexión y la ensoñación de los males humanos es obsesiva en Flaubert. Repasadas, constante y prolongadamente,

9 Epístola enviada a L. Colet el 6 o 7 de agosto de 1846. 
esas experiencias fueron iluminadas, y reforzadas, por la lectura de autores románticos y clásicos, y por la escritura de reseñas y obras de teatro que, con su hermana y amigos, montó y representó. Él era consciente de su ensoñación de los males humanos, de ese monstruo el cual atrae y devora, de esa sirena de las almas que canta, llama, y que cuando uno va a ella ya no regresa. La ensoñación de... deviene en disposición de sí. Lector de moralistas antiguos - Platón, Marco Aurelio, Epicteto, Lucrecio, Plutarco, Apuleyo, entre otros-, de moralistas modernos - Montaigne, La Bruyère, Rousseau, entre otros-, de Shakespeare ${ }^{10}$, de Voltaire, de Goethe y de Byron; Flaubert aprendió los efectos temibles de las pasiones ${ }^{11}$, se familiarizó con la miseria de la condición humana y la estulticia de su siglo. Su temprano acceso al pensamiento moral, a las maneras de vivir, a la reflexión constante sobre su existencia y la de los otros lo condujeron a la insoportabilidad de la bêtise moderna.

En toda su amplitud, en toda su profundidad, la forma de vida es el problema mayor del pensamiento y la existencia de Flaubert. ¿Cómo vivir en un siglo donde la bêtise se produce y se promociona democrática e industrialmente, se difunde socialmente y se inocula a través de excitaciones sin fin? ¿Cómo conducirse frente a la moral, los valores y las reglas prescritos o propuestos por la cultura de tiempo? ¿De qué manera conducirse frente a las pasiones y los sufrimientos humanos? Flaubert responde: «Subo en mi torre de marfil y cierro mi ventana [...] pues si no, más vale romperse la cabeza, o volverse loco» (Flaubert, 1991, pp. 403$404)^{12}$; «[...] la vida es una cosa de tal manera hedionda que el único medio de soportarla es evitarla. Y se la evita viviendo en el Arte [...]»(Flaubert, 1980, p. 717) ${ }^{13}$. Esta última expresión es

10 Flaubert aprendió inglés para leer y releer la obra de Shakespeare.

11 En la época de Flaubert la noción de pasión todavía no se había disuelto en los términos más suaves de sentimientos o afectos ni es objeto de alabanza; todavía conservaba la gravedad que le asignó la cultura occidental desde los griegos. La pasión era la fuente de la agitación, del estremecimiento, de la inconstancia, de la necedad, de la desdicha y de toda la hiperbolización de la locura de los hombres.

12 Epístola enviada a A. Bosquet el 9 de agosto de 1864.

13 Epístola enviada a L. de Chantepie el 18 de mayo de 1857. 
una divisa y una consigna compleja. Evitar la vida indica evitar la forma de vida común y general a todos; y al eludir esa forma, se soporta su propia existencia bajo la condición de darse a sí mismo otra forma.

La insoportable agitación y la insoportable levedad de la vida activa, práctica, común y visible a todos — términos sinónimos-, lanzan a Flaubert a la construcción de una vida contemplativa de la belleza; es decir, a la forma de vida-artista. Varias ideas subyacen en la consigna. La primera, la miseria, el sufrimiento y la bêtise son inmanentes a la condición humana; su carácter irremisible, borra toda esperanza de perfectibilidad. Ningún individuo escapa a la condición humana; sin embargo, hay diversas maneras de conducirse frente a esa trinidad fatal. La segunda, escapar de la vida práctica implica un arduo trabajo sobre sí mismo, un proceso en el cual uno se reconstituye y recompone su propio modo de ser. Este proceso es una experiencia de desgarre, de desprendimiento de uno mismo, una manera de des-subjetivación y, simultáneamente, el advenimiento de otra manera de las relaciones de sí consigo mismo. Por lo que Flaubert dice: «El único [...] medio de soportar la existencia es aturdiese en la literatura como en una orgía perpetua. El vino del arte causa una larga embriaguez y es inagotable. Pensar en sí es que lo vuelve a uno desgraciado» ( $\mathrm{p}$. $832)^{14}$. En este sentido, se está enfermo cuando se piensa en sí mismo, es decir, cuando se actualiza la condición humana en la relación establecida consigo mismo, desde el momento en cual uno deja valer, quiere hacer valer y hace valer sus pasiones, sus deseos, sus ambiciones, entre otros elementos. Flaubert se embriaga con arte, como otros lo hacen con aguardiente. En la embriaguez no hay rastro alguno del tedium vitae; «[...] cuando caigo en mis desánimos, el hombre se despierta con todos sus apetitos y todos sus vicios. ¡Uno tiene tanta necesidad de destensionarse el alma!» (Flaubert, 1980, p. 762) ${ }^{15}$.

14 Epístola enviada a L. de Chantepie el 4 de septiembre de 1858. 15 Epístola enviada a L. de Chantepie el 23 de agosto de 1857. 
Sin arte, Flaubert es un pobre hombre lleno de miserias, tal como aquel rey de Pascal el cual quiere ser rey solo para divertirse, es decir, para no ver su miserable condición; el rey busca que otros lo diviertan todo el tiempo, él quiere divertirse, se esfuerza por divertirse. El divertimiento rueda sobre la posibilidad de crear constantemente escenarios diferentes, los cuales procuran excitaciones que arrastran como un remolino sin tregua. $\mathrm{Y}$ hay que mendigar el divertimiento so pena de caer en la gravedad de la existencia. Mas Flaubert no era un hombre de divertimiento:

[...] yo, i«un hombre de boulevard, un hombre a la moda, acomodado»! [...]. Yo soy, por el contrario, lo que se llama un oso. Vivo como un monje; algunas veces (igualmente en París), permanezco ocho días sin salir [...]. ¡En cuanto a eso que se dice el mundo, jamás, jamás voy... Yo no sé ni danzar, ni valsar, ni jugar ningún juego de cartas, igualmente ni conversar en un salón, porque todo eso que se sigue ahí me parece inepto! (Flaubert, 1980 , p. 795$)^{16}$.

En sí y por sí, los divertimientos no distraen como las excitaciones no excitan; puesto que el divertimiento es un uso de sí mismos. El êthos ha de tener afinidad con la manera fugaz del divertimiento para que este pueda alcanzar su razón de ser, divertir o lograr el extravío. Sí, en algunos momentos Flaubert deseaba lanzarse a una afección nueva que lo sustrajera de su melancolía - sobre todo cuando su soledad había devenido larga y penosamente-, pero tal cosa era imposible:

[...] yo no pediría mas $[s i c]$ que lanzarme a una afección nueva. ¿Mas cómo hacerlo? Puesto que mis viejos amigos están casados, son oficiales, piensan en su pequeño negocio durante todo el año, en la caza durante sus vacaciones, y en el whist después de cenar. No conozco uno solo que sea capaz de pasar conmigo una tarde leyendo un poeta (Flaubert, 1998, p. 190) ${ }^{17}$.

16 Epístola enviada a L. de Chantepie el 23 de enero de 1858.

17 Epístola enviada a G. Sand el 21 de mayo de 1870. 
Los divertimientos vulgares, comunes, no divierten a un hombre de espíritu. En el verano de 1874, Flaubert fue a un balneario en Suiza por prescripción médica y sugerencia de algunos amigos; le habían recomendado esto para calmar sus agitaciones nerviosas, pasear, descansar, respirar el aire de las montañas, complacerse viendo la naturaleza. Mas él sentía solamente un tedio intenso debido a la ociosidad y la soledad; y además no era un «hombre de la naturaleza». Con gusto cambiaría los glaciares de los Alpes por un museo del Vaticano; dado que las bellezas naturales lo entusiasmaban mucho menos que las del arte. La naturaleza lo aplastaba sin inspirarle ningún "gran pensamiento». En esa situación, refiriéndose a la naturaleza, Flaubert (1998) atestaba: «[...] yo he tenido el deseo de decirle interiormente: "Esto es bello; hasta luego, yo he salido de ti; dentro de algunos minutos volveré a entrar: déjeme tranquilo, yo pido otras distracciones"» (p. 821) ${ }^{18}$. Flaubert se da por meta existencial, la tranquilidad, y la tranquilidad se la procura la literatura. Fuera de ese fin y ese recurso, su vida discurre al carpe diem, sin proyectos y sin divertimiento. Un lustro antes de su muerte escribe a G. Sand:

Una gota errante, dolores que se pasean por toda parte, una invencible melancolía, el sentimiento de "la inutilidad universal" y grandes dudas sobre el libro que hago, he aquí lo que tengo [...] voy a ponerme de nuevo a trabajar sin mirar a tras de mi [...]. No voy a salir de mi casa - de aquí a mucho tiempo, pues quiero avanzar en mi tarea, la cual me pesa sobre el pecho como 500 mil kilogramos - [...]. Es verdad que yo estoy dotado de una sensibilidad absurda [...]. ¡Que no sea yo organizado por la alegría como lo soy por el dolor! [...]. Pero uno no organiza su destino. Uno lo sufre. Yo he vivido siempre con el día a día, sin proyectos futuros y persiguiendo mi meta (una sola, la literatura) sin mirar ni a la izquierda ni a derecha. Todo lo que estaba alrededor mío ha desaparecido, y ahora me encuentro en el desierto. En breve, el elemento distracción me falta de modo absoluto (Flaubert, 1998, pp. 924-925) $)^{19}$.

18 Epístola enviada a I. Tourgueneff el 2 de julio de 1874.

19 Epístola enviada a G. Sand el 10 de mayo de 1875. 
Para Flaubert, como para Montaigne, cada jornada era su fin. $\mathrm{Al}$ ver profundamente en el fondo de las cosas, y al reflexionar seriamente, se dedicaba a "cultivar su jardín», es decir, el libro en el que trabajaba. He ahí su lección moral. Ni alcanzó, ni buscó esas habilidades sociales usadas comúnmente para triunfar o, al menos, para sobrevivir sin melancolías en la vida social. Como Montaigne, Flaubert se retiraba en su morada, en su refugio de Croisset o, como lo llamaba algunas veces, en su «madriguera». Ahí, se procuraba la soledad que lo protegía del bullicio y agitación de los otros, soledad la cual aumentó con los años de su vida. Situación evidenciada cuando decía «[... yo tengo igualmente el deseo de comprar un bello oso (en pintura), hacerlo enmarcar y colgarlo dentro de mi habitación, después de haber escrito abajo: retrato de Gustave Flaubert, para indicar mis disposiciones morales y mi humor social» (Flaubert, 1973, p. 238) ${ }^{20}$.

En el fondo de uno mismo se ha de tener un lugar propio, solo para uno, donde uno se encuentre consigo mismo, donde uno ejerce su libertad y vive en tranquilidad ${ }^{21}$. La trastienda de Montaigne, o la ciudadela interior de Marco Aurelio, deviene en la «torre de marfil» de Flaubert. Lo que en cierto momento recomienda a su hermana, él lo hizo para sí, y dijo: "Recuérdate de la trastienda (arrière-boutique) de Montaigne, que tú has admirado, y aplícate a hacerte una» (Flaubert, 1973, p. 127) ${ }^{22}$. Flaubert se construyó su trastienda, una fortaleza de muros estoicos.

La mayor referencia moral del estoicismo, la radical distinción entre lo que depende y lo que no de uno mismo. Flaubert la pone en uso bajo los modos de vida contemplativa y la vida práctica, o 20 Epístola enviada a E. Chevalier el 15 de junio de 1845.

21 Esta idea-estrategia del estoicismo, es plausible que Flaubert la haya encontrado en Montaigne: «Hay que reservarse una trastienda [arrière-boutique] toda nuestra, toda libre, en la cual establezcamos nuestra verdadera libertad y nuestro principal retiro y soledad. En ella hay que mantener nuestra ordinaria conversación de nosotros con nosotros mismos, y tan privada que no tenga cabida ninguna relación o comunicación con cosa ajena [...] Tenemos un alma contorneable en sí misma; puede hacerse compañía, tiene con qué atacar y con qué defender, con qué recibir y con qué dar: no temamos, en esta soledad, podrirnos de ociosidad tediosa» (Montaigne, 1999, p. 241). Flaubert conoce la formulación de Montaigne, y a su amante le dice: "[...] cuéntame lo relegado en la trastienda [l'arrière-boutique]» (Flaubert, 1973, p. 420).

22 Epístola enviada a su hermana Carolina el 12 de noviembre de 1842. 
activa. Su uso propio de la vida, y solo para él, es una vida dedicada a la contemplación, manifestación y producción de lo bello. La vida filosófica de otrora se declina ahora en vida estética.

La vida contemplativa de Flaubert emerge en toda su plenitud a partir de su grave crisis nerviosa de 1842, cuando contaba con 22 años, mas su proceso de gestación empieza posiblemente desde su infancia. Unos meses antes de alcanzar sus veinticinco años escribió:

[...] aquel que vive ahora y que es yo no hace más que contemplar al otro, que está muerto. Yo he tenido dos existencias bien distintas; los acontecimientos exteriores han sido el símbolo del fin de la primera y del nacimiento de la segunda; todo eso es matemático (Flaubert, 1973, p. 322) 23. $^{23}$.

Cuando la enfermedad de Flaubert se hiperbolizó, devino en una experiencia moral crítica $^{24}$ (al tomar este último término bajo el sentido de la medicina griega, punto crítico de una enfermedad a partir del cual se genera una distinción, una separación). En esa experiencia de sí, por una parte, sale a la luz la forma de vida estética; y por otra, muere la vida prosaica, ambiciosa, apasionada, agitada, plena de contradicciones y percepciones diversas. Entre las dos formas de vida hay una separación matemática, cuyo símbolo son una serie de acontecimientos externos; pero la emergencia de una como la desaparición de la otra se encuentran agenciadas por un trabajo largo e intenso sobre sí mismo. En el advenimiento de la vida-artista, Flaubert diferencia netamente dos partes de su êthos - dos tipos de relaciones-, una externa y otra interna. Una relación de sí con el mundo marcada por lo variado, lo multicolor, lo armónico, lo inmenso; una disposición al espectáculo en el que se alegra el espectador sin desear, en absoluto, ser actor. La disposición y la función de esta relación parece ser afirmada, cuando aclara a su amante Colet:

23 Epístola enviada a L . Colet el 31 de agosto de 1846.

24 Este término se toma bajo el sentido de la medicina griega, donde se expresa como punto crítico de una enfermedad a partir del cual se genera una distinción, una separación. 
[...] no obstante yo no he renunciado a nada de la vida, como tú pareces creerlo. Yo abro, como todos los otros, las narices para sentir las rosas y los ojos para contemplar la luna. Amor y amistad, yo no he rechazado nada. Al contrario, yo he cogido los lentes para distinguirlas más claramente (Flaubert, 1973, p. 322) ${ }^{25}$.

En la relación interna, relación de sí consigo mismo, marcada por su concentración y densidad, hay una disposición en función de recibir la luz del espíritu, es decir, los efluvios del pensamiento de la humanidad a través de las emanaciones de los grandes hombres que han transitado la historia. Si en sí mismo, Flaubert hizo dos prenses, el pliegue se sostuvo sobre una elección existencial radical, cuando escribía frases como «[...] yo he dicho a la vida un irrevocable adiós» (Flaubert, 1973, p. 229) ${ }^{26}$. ¿Cuál fue el alcance, o qué implicó ese irrevocable adiós? Ante todo, se trató de un desprendimiento de la vida práctica o, mejor, de un desprendimiento de sí mismo, de otro tipo de uso de sí. Arrancase de sí aquellas disposiciones o al menos refrenar los deseos que empujan y lanzan a la vida práctica, activa, o común, donde se ha de ejercer el rol de actor y protagonista de acciones prosaicas. Despedirse de la «vida práctica» indica desprenderse del estatuto del sujeto moral que instauran las reglas, los discursos de verdad, los valores prescritos por los regímenes morales o propuestos por los agenciamientos de la cultura del siglo. Sin embargo, en varios momentos, Flaubert se vio apremiado a jugar su rol activo en la turbulencia de la vida común de los hombres; por ejemplo, en el affaire con Colet -el proceso por inmoralidad pública-, cuando los prusianos invadieron su pueblo, su casa, y buena parte de Francia; se alistó en el regimiento de defensa, cargó sus armas; $y$, cuando advino la quiebra económica de su sobrina, incapaz de asumir la extrema pobreza, Flaubert se vio enredado en la gestión vergonzosa de una pensión y de un empleo. Otras veces, dijo: "[...] no obstante, yo me he me mezclado algunas veces con ella: pero por fuga, por crisis - y muy rápido he vuelto ( $\mathrm{y}$ vuelvo) a mi naturaleza real que es contemplativa» (Flaubert, 1980, p. 697) ${ }^{27}$. 25 Epístola enviada a L. Colet el 31 de agosto de 1846. 26 Epístola enviada a Le Poittevin el 13 de mayo de 1845.

27 Epístola enviada a L. de Chantepie el 30 de marzo de 1857. 
Uno no escapa a la condición humana, uno se tiene en la tierra. Flaubert conoce muy bien a Montaigne. Él ha situado su vida más allá de la esfera común, se ha retirado de las ambiciones y vanidades para encontrar algo más sólido en función de obtener no la felicidad, sino el reposo. “¿Error! Siempre está en nosotros el hombre, con todas sus entrañas y ataduras poderosas que lo amarran a la humanidad» (Flaubert, 1973, p. 260) ${ }^{28}$. Idea a la cual vuelve trece años después al indicar:

[...] por más que se intente apartarse de todos los asuntos y afecciones humanas, uno está siempre sobre la tierra; y no se ha dado tres pasos sin que uno se desgarre con todas las espinas o que uno se hunda en el fango (Flaubert, 1991, p. 43) ${ }^{29}$.

Dejemos resonar: a la vida práctica, Flaubert contrapone la vida contemplativa, mas uno no escapa a la condición humana. Frente a estas situaciones, ¿cómo queda situada la vida-artista? En Flaubert, por ejemplo, sus melancolías persisten, sean inducidas por la muerte de las personas a las que profesa sus afectos, o sea el caso de la soledad que, aunque buscada, pesa - y sobre todo en sus últimos años, cuando han desparecido casi todos sus amigos- - Por otra parte, si bien Flaubert deja de lado el lamento por el fango de la vida, jamás puedo desprenderse de su rabia visceral y militante emanada de la bêtise moderna que le rodeaba por doquier. «Yo no he podido llegar al estoicismo, al que nada le hace y que no lo revuelve más la bestialidad que el crimen: pero he llegado a librarme completamente de lo que me puede mostrarme la bêtise humana» (Flaubert, 1973, p. 387) ${ }^{30}$. Esquemáticamente, parece plausible considerar que la vida-artista está constituida por dos maneras de conducirse en la vida; la primera, en el alejamiento posible de vida práctica y en la modulación o control constante de la conducta cuando ha de vérselas con los asuntos propios de la condición humana; y la segunda, en la producción, la manifestación y la contemplación de la belleza donde se pone

28 Epístola enviada a E. Vasse el 5 de abril de 1846.

29 Epístola enviada a J. Sandeau el 1 de octubre de 1859.

30 Epístola enviada a L. Colet el 13 de octubre de 1846. 
en juego la despersonalización o desubjetivación. Dos maneras coexisten, una tranquila e intensa, y la otra, perturbadora y modulada; sus conexiones son heterogéneas sin síntesis posible. La intensidad, profundidad y alta definición de la vida contemplativa permite fijar sin confusión los linderos que la separan de la vida práctica. Claramente definidas y delimitadas, dos formas de vida se reconocen en Flaubert. No llama la atención el hecho de que un hombre tenga diferentes maneras de vivir, lo sorprendente es la presencia de dos formas claramente definidas; puesto que, en los seres humanos coexisten varias maneras de existir, según los dominios de las cosas donde el individuo juega el papel de sujeto. Situación que hace difícil las distinciones.

Flaubert, al usar el arte, se afectó a sí mismo en su uso. Su estilo de existencia (vida-artista) fue una experiencia de sí sobre sí mismo, una práctica ascética coordinada con un régimen del arte (que fija la idea de belleza como la verdad del arte) y con un régimen moral (que sostiene la idea de la tranquilidad como verdadera vida). Cuando Flaubert descubrió que, a propósito del arte y de la moral, algo pasa por verdadero; se dispuso a efectuar la experiencia capital de su existencia. Flaubert ni inventó las verdades que marcan sus prácticas, ni escapó a los efectos que inducen; sin embargo, hizo jugar a la verdad otros juegos con otras reglas diferentes a las prescritas o propuestas por su siglo. Una práctica existencial, interferida por los discursos de verdad el arte y la moral, hace que aquello que no existía, y que no existe en sí - vida-artista-, devenga en la forma que marca su práctica real de existir. La vida-artista se instaura como el estilo que Flaubert da a las relaciones que establece consigo mismo y con los otros; relaciones afectadas, modificadas y transformadas por la existencia de discursos de verdad, por los efectos que estos mismos inducen, por las obligaciones que imponen y por las promesas que formulan. La vida-artista emerge en el entrecruzamiento de las relaciones entre arte y filosofía, es decir, en la moral estética. 
Llega el momento de concluir este segmento. Primero, en el siglo XIX una serie de discursos de verdad de naturalezas disímiles, con registros diversos y correspondientes a dominios distintos, entablan conexiones heterogéneas. Un régimen estético define la verdad del arte y el arte en su verdad; un régimen moral define la verdad de la vida y la vida en su verdad. Así, al entrecruzar la verdad de la estética y la verdad de la moral, Flaubert hizo la mayor composición de su existencia: su vida-artista. Segundo, al haber vivido en un mundo que le negaba las seguridades que su vida reclamaba, Flaubert se vio lanzado a buscar y construir su salvación a través de la estética. Su moral en este sentido se hizo efectiva a través de una constante práctica de si $^{31}$. Él se aplicó a trabajar arduamente sobre sí mismo para transformarse y producir un modo de ser el cual lo condujera a la tranquilidad y la libertad. El êthos, constituido por la relación que tienen las personas consigo mismas, deviene en el objeto de una tecnología —-tema del capítulo siguiente-.

31 Foucault dice: «Uno se constituye como sujeto en la relación con sí, el sujeto no es dado [...] no es suficiente decir que el sujeto se constituye en un sistema simbólico; el sujeto se constituye en prácticas reales, en prácticas históricamente analizables. Y hay una tecnología de la constitución del sujeto que, utilizándolos, atraviesa los sistemas simbólicos, pero no es simplemente por el juego de sistemas simbólicos que el sujeto se constituye» (Foucault, 2015, p. 178). 


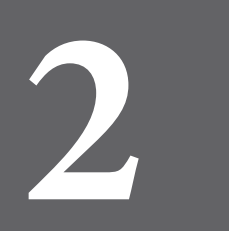

CAPÍTULO DOS 

Querido amigo, tú tienes razón en decir que el día de año nuevo es estúpido [...] yo escribiré comedias y tú escribirás tus sueños, y como hay una dama que viene a casa de papá y que nos cuenta siempre bestialidades [bêtises], yo las escribiré (Flaubert, 1973, p. $4)^{32}$.

Muy temprano, cuando cuenta con nueve años, Flaubert percibe la bêtise $e^{33}$ (bestialidad), y la dispone como materia de observación y de escritura. Cuando cuenta con treinta y dos, piensa que «[...] la tristeza de Molière, sin duda, venía de toda

32 Epístola enviada a E. Chevalier el 1 de enero de 1831.

33 En el presente trabajo se usa el término francés bêtise bajo la acepción de bestialidad; mas se prefiere no traducirlo, puesto que en español no hay una palabra precisa para traducir dicho término sin perder el fuerte sentido que le confiere Flaubert. Bêtise designa varias cosas, o mejor, envuelve el sentido de varias palabras, tales como bestialidad, estolidez, imbecilidad, estupidez, tontería, necedad, o estulticia. Al respecto, Cámpora (2011) escribe: «[...] la palabra "bêtise” en francés es polisémica y gradual y parece no haber equivalencia en español que cubra la totalidad de acepciones. Esta situación adquiere proporciones considerables desde que se trata de traducir a Flaubert: en francés flaubertiano la palabra "bêtise" se extiende, como se sabe, sobre toda una gama de significados, y el sentido y el grado de matices que Flaubert le atribuye cambian incesantemente según el contexto» (p. 1). 
la bêtise de la Humanidad que sentía comprimida en él. Sufría de los Diafoirus y de los Tartufos que le entraban a través de los ojos al cerebro» (Flaubert, 1980, p. 444) ${ }^{34}$. Flaubert ve aquello que, estando ante los ojos, los otros no ven. La soberbia y la levedad de la bêtise de su siglo lo penetran y, comprimiéndose, se instaura en la fuente de emanación de su melancolía eminente. La bêtise afecta la existencia y fustiga el pensamiento. Proteger la existencia, componer una vida otra, es una necesidad de Flaubert. La bêtise, por un lado, abre el camino que conduce a la salvación de la vida $y$, por otro, a la creación de una obra eminentemente crítica y contra-cultural. Se puede considerar que la bêtise funciona como el operador estético-crítico de la vida-artista de Flaubert y de su obra de arte de escritura. Por el término operador se entiende un postulado o un concepto, el cual explica un tipo de pensamiento $y$, a la vez, obtiene su fundamentación y coherencia dentro de la misma racionalidad que instaura ese pensamiento; mas también un postulado que marca con su impronta las prácticas no discursivas y discursivas, la existencia y la escritura. En este capítulo se ensaya desbrozar la noción de bêtise de Flaubert como operador estético-crítico de su existencia y de su obra.

Hay escritores y artistas que hacen de sus obras un repositorio de tonterías. Sus estupidarios no dan qué pensar, no fustigan el pensamiento, no rebasan el nivel anecdótico y no provocan nada en su insípida psicología. En el pensamiento de Flaubert, en su manera de vivir y en sus obras, la bêtise se dispone como una cuestión filosófica la cual obliga a pensar. «La mala literatura hace tontarios [...] [y] la mejor fue perseguida por el problema de la bêtise, que ella supo conducir hasta las puertas de la filosofía, dándole toda su dimensión cósmica, enciclopédica y gnoseológica (Flaubert, Baudelaire, Bloy)» (Deleuze, 2011, pp. 196-197). Algunos filósofos como Sartre, Deleuze y Rancière, han visto en Flaubert dos nociones y dos usos de la bêtise manifestados en su existencia y en su obra; tal como lo muestra la síntesis presentada por Zabunyan en su artículo La bêtise: «faculté pitoyable»ou

34 Epístola enviada a L. Colet el 30 de septiembre de 1853. 
«faculté royale»? -Deleuze lecteur de Flaubert (2007)—. Existen dos nociones de bêtise, y no una; hay un redoblamiento que corresponde al trabajo del escritor. Por una parte, sobre un plano empírico, ordinario en la vida cotidiana, sobre el que ejerce su crítica; y por la otra, sobre un plano literario que eleva al escritor a un nivel en el que alcanza tales intensidades que lo llevan a la petrificación en su contemplación, a confundirse con ella (Zabunyan, 2007). Al respecto, Sartre escribe:

[...] Flaubert reúne bajo el mismo nombre dos Bêtises contradictorias, una de las cuales es la substancia fundamental y la otra el ácido que la corroe. Entre ellas la lucha es continua y el match siempre nulo. Una cosa es segura: bajo un aspecto o el otro, la Bêtise triunfa siempre (Sartre, 1988, p. 612).

Para el autor de El idiota de la familia, esos dos tipos de bêtise se confrontan sin cesar, una le fascina a Flaubert y la otra le repugna. La primera (la fundamental) corresponde a una objetividad difusa de las conductas, a una reificación de los sentimientos, a una materia que agita el espíritu hasta convertirlo en una piedra. El pensamiento se hace materia y la bêtise solo posee el espesor positivo de la misma. Ahí se trata de una síntesis pasiva con la plenitud del ser, la cual corresponde a una especie de animalidad, a un "pensamiento salvaje» y a una "razón decapitada» que no produce ninguna objetividad del pensamiento, puesto que, solamente se idéntica con la materia y el pensamiento se petrifica. El segundo tipo de bêtise (la analítica) es la disección subjetiva de las conductas ordinarias de los hombres y la clase burguesa, una crítica llevada a toda la humanidad. No obstante, Flaubert comporta en sí mismo ese lenguaje que critica, los rastros de las conductas que objeta están en él, no llega a despojarse de todo aquello. En ambos casos, el escritor está condenado al fracaso. Sartre sostiene que los dos tipos de bêtise están motivados por el negativismo y el abstencionismo de aquel, es decir, por la complejidad de la relación que sostiene con su clase social, a saber, por su manera de ser burgués - el burgués el cual es y rechaza serlo- (Sartre, 1988). 
El análisis de la bêtise efectuado por Sartre es inseparable de su método dialéctico, de las categorías de ideología y representación, del conflicto de clase social y de la relación psicológica del hijo Flaubert con su padre. La génesis de los sentidos y los usos de las dos nociones de bêtise en este último autor se fijan desde el punto de vista de la constitución de su personalidad, el cual corresponde a las preocupaciones que motivaron el voluminoso trabajo de Sartre sobre este, y donde se preguntó «¿Qué podemos saber de un hombre, hoy?» (Sartre, 1988, p. 7). La pregunta está atravesada por una apuesta fenomenológica la cual pone en juego una serie de análisis que se ordenan dialécticamente y vinculan la homogeneidad entre un universal (la cultura) y un singular (una vida). Sartre asume la vida de un hombre como una singularidad la cual, a través de sus proyectos, totaliza lo universal tal como una porción de un todo; por ejemplo, donde la vida de Flaubert aparece como un universal singular que niega radicalmente la individualidad y la creación única. La cuestión de la bêtise queda inscripta bajo el signo de una relación dialéctica entre un universal dado y un singular efectuado a través de los operadores teóricos de las representaciones y las ideologías.

Deleuze no hace una monografía de Flaubert, mas retoma su noción de bêtise, y la pone en juego como una cuestión mayor del pensamiento filosófico. Hay una bêtise formidable que pone en cuestión el pensamiento todo - corresponde a una dimensión trascendental-; hay una bêtise lamentable que es el juego de la estupidez común en la vida ordinaria de los hombres - dimensión empírica-. Para el filósofo, la bêtise debe ser examinada por derecho, esa es la lección que la filosofía recibe de la literatura, que ha sabido tomar el fenómeno más allá de sus determinaciones empíricas, más allá de las determinaciones de la psicología común o del simple anecdotario. En la bêtise está en juego la práctica misma de la filosofía: ella es el mayor enemigo del pensamiento; no es al error, sino a la bêtise a lo que se debe enfrentar la filosofía. Apuntando directamente a sus estructuras, la bêtise es el verdadero 
negativo trascendental del pensamiento; puesto que en ella está comprometida la génesis del pensamiento y la posibilidad misma del pensar.

Sería suficiente que la filosofía retome este problema con sus propios medios y con la modestia necesaria, considerando que la bêtise no es jamás aquella de los otros, sino el objeto de una cuestión propiamente trascendental: ¿cómo la bêtise (no el error) es posible? (Deleuze, 2011, p. 197).

Por su parte, Rancière ve en el pensamiento de Flaubert dos tipos de bêtise que convergen en su obra de arte de escritura: la bêtise del mundo prosaico, ordinaria, empírica; y la bêtise del arte, pensada y trabajada filosóficamente. La bêtise del mundo se va a instaurar en la bêtise del arte; Flaubert redobla en el arte el vacío y la banalidad que rodea la palabra. La tarea de la bêtise del arte es mantener la bêtise del mundo prosaico en el arte. El estilo, como una manera absoluta de ver las cosas alcanza su mayor expresión en la bêtise, puesto que: «[...] escribir es ver, devenir ojo, poner las cosas en el puro medio de su visión, es decir, en el puro medio de su idea» (Rancière, 2010a, p. 106). Flaubert artista crea el poema en prosa y lo hace coincidir con la prosa del mundo prosaico: la materia del poema en prosa es la misma materia de la prosa del mundo (bêtise moderna): identidad entre el poema y el mundo. «La presencia del artista en su obra [...] consiste en su diseminación. Consiste en ser el medio de esta disolución. El estilo es un quehacer de frases solo porque él es de entrada un quehacer de "concepción"» (Rancière, 2010a, p. 108).

El poema [en] prosa es posible porque la "prosa del mundo" no es más que el orden superficial en el cual se efectúa la potencia del gran desorden. No es necesario "volver a poetizar" la realidad prosaica. Ella misma presenta su disolución a la mirada atenta (Rancière, 2009, p. 142). 
El mundo se va él mismo en frases singulares. Los órdenes racionales del mundo son solo superficiales. Su fondo efectivo y su operador es la potencia del desorden, la fuerza de relación de las no-relaciones; por lo tanto, el poema en prosa de Flaubert no requiere repoetizar, la misma realidad prosaica hace visible su disolución. El estilo coincide con la realidad del mundo mismo. Ese quehacer de concepción, ese modo de pensamiento transforma la manera de la ficción en las obras de arte de escritura al borrar la ontología que subyace en el sistema representativo.

Sartre, Deleuzey Rancière coinciden en que, en el pensamiento de Flaubert, subyacen dos nociones de bêtise; mas cada uno la lanza al corazón de sus preocupaciones sea como una cuestión inscrita bajo el signo de las ideologías y representaciones, sea bajo el signo de una facultad trascendental, sea bajo el signo del estilo de la obra de arte de escritura, donde subyace un fundamento metafísico. En este trabajo se considera la noción de bêtise como operador estético crítico de la vida y la obra de Flaubert, una noción que forma dos prenses: bêtise moderna y bêtise formidable. Entre los dos prenses hay una relación de oposición, oposición que separándolos los vincula; una relación que no es de tipo dialéctico, sino de orden heterogéneo, sin síntesis posible. La polaridad de la bêtise corresponde a la polaridad que Flaubert asigna a las formas de vida: vida práctica y vida contemplativa.

\subsection{Bêtise moderna}

La noción de bêtise moderna designa la estolidez, la bestialidad, la estupidez, la insensatez, la tontería y la estulticia de las maneras de vivir comunes y generales del siglo XIX. El burgués es su mayor representante, entendido no como clase social (el proletario, el campesino, el soldado, el sacerdote, la prostituta, el emperador, el artista, entre otros forman parte de especie selecta), sino desde el punto de vista de su modo de ser expresado en sus comportamientos; «[...] los burgueses, es decir todo el mundo 
[...]» (Flaubert, 1991, p. 170) ${ }^{35}$. Burgués es el nombre del êthos del siglo XIX, de un modo de ser, de una manera de pensar y decir, de sentir y desear, de saber y hacer. La bêtise moderna no señala hacia una deficiencia natural del entendimiento de los hombres; designa un fenómeno cultural, un acontecimiento en la historia de los modos de vida propios de los tiempos modernos. Cada época produce su propia bêtise, y produce tanta como necesita y como puede. El consenso de la cultura produce, propone, promociona, prescribe su bêtise a través de sus dispositivos de poder, de sus discursos de verdad, de sus tecnologías de subjetivación — gestión de aquello que comúnmente se envuelve en el término identidad de los individuos-. Figurativamente, se puede considerar la bêtise moderna como una proyección ortogonal de un diagrama de fuerzas sobre la forma de vida. Diagrama moderno de fuerzas que siguen diferentes direcciones, fuerzas cuyas fuentes son los haces de relaciones de la industrialización, del capitalismo democrático, de los nuevos discursos y campos de saber, de las novedosas tecnologías de producción, de dominación, de subjetivación y de comunicación. La bêtise moderna es el agenciamiento del gobierno de los hombres a través de la conducción de las conductas. Esta es liberal, es decir, un modo de ser producido y agenciado por el liberalismo gubernamental.

Rancière ve que, en los tiempos meridianos del siglo XIX, en Francia resuena la palabra «excitación» como el eco del advenimiento de una sociedad convertida en un tumulto incesante de deseos y pensamientos, apetitos y frustraciones. Taine, por ejemplo, capta lo siguiente:

[...] la necesidad de excitación es la gran palabra; alcanzar la luz, en el gran día, tener los nervios removidos, sentir la sensación intensa de la alegría, tener vino de champagne en la cabeza, nada más francés, hay un poco de madame Bovary en cada francés (Taine, 1867, p. 45).

35 Epístola enviada a E. Feydau el 17 de agosto de 1861. 
La «necesidad de excitación», al habitar el alma de los individuos, es el signo de la modernidad marcada por los acontecimientos de la revolución francesa, la industrialización y la democracia capitalista. En el viejo orden, en la monarquía y la religión, en la aristocracia y el pueblo, tenían su sitio definido; un dispositivo rígido determinaba el lugar correspondiente y conducía a cada grupo y a cada individuo en su orden concerniente. El estatuto de cada grupo, y de cada individuo, se sometía a horizontes limitados, sus fronteras - firmes y claras - marcaban lo que se podía desear, lo que podía alcanzar, lo que correspondía hacer en y con la existencia. En el siglo XIX, algunos espíritus ven en el êthos burgués la subversión de ese orden de otrora. Ahora, hay «[...] una necesidad irresistible de placer, de excitación, de acción, los nervios tendidos como cuerdas de harpa, una voluntad que no sabría jamás contenerse, ni subordinarse, ni regularse» (Taine, 1867, p. 90).

Llamaron a esa «necesidad de excitación», sin fin y sin meta, democracia. Se trataba, sin duda, de una democracia de la sensibilidad, del êthos, de la forma de vida.

Era la insurrección de esa multitud de deseos y aspiraciones que surgían de todos los poros de la sociedad moderna, la insurrección de la infinidad de esos átomos sociales en libertad, ávidos de gozar de todo lo que constituía objeto de goce: el oro, por supuesto, y todo lo que el oro puede comprar, pero también, lo que resultaba peor, todo lo que no puede comprar: las pasiones, los ideales, los valores, los placeres del arte y de la literatura [...]. Las cosas hubieran sido tanto menos graves si la gente humilde hubiese querido simplemente volverse rica. Pero ellos entendían de una manera un poco extraña esa "positividad". Querían gozar de todo lo que es susceptible de goce, comprendidos los placeres ideales. Pero también querían hacer de esos placeres ideales placeres concretos, placeres materiales positivos (Rancière, 2010, pp. 80$81)$. 
Los sueños, las aspiraciones, las ambiciones, las pasiones -que seducen y arrastran sin reposo ni retorno- eran puestos en palabras y en imágenes (daguerrotipos, dibujos, caricaturas) y promovidos por los nuevos medios de comunicación, por ejemplo, los diarios, los libros baratos de escaparate, las litografías. Todo estaba a disposición de cualquier individuo. Por esa época ya se veía la sociedad moderna como un cuerpo social bullicioso, constituido por individuos libres e iguales y arrastrados por un torbellino sin reposo que los lanzaba tras la búsqueda de la excitación, de la interiorización de la agitación sin meta ni fin.

Conocer la vida; entienda por eso la embriaguez, la sensación intensa, la palpitación del corazón, de los nervios, el remolino que arrastra todos los sentidos y la cabeza [...]. Ninguno mide los huecos, los vacíos sin fondo que uno encuentra bajo la corteza uniforme del hielo mundano (p. 99).

La «excitación» es un signo inscripto en aquello que Rancière denomina «reparto de lo sensible». Por ejemplo, el filósofo ve que, en Madame Bovary, los rasgos de Emma responden a la gran obsesión de su tiempo, a la excitación:

Emma quiere a la vez el idilio ideal y el placer físico. Y pasa su tiempo negociando entre las excitaciones de los sentidos y las del espíritu. Cuando se resiste a su amor por León, cree merecer una recompensa. Entonces compra un mueble. Y no cualquier mueble: un reclinatorio gótico. Esa es la marca, para los buenos espíritus, de la terrorífica equivalencia democrática de todo con todo: cualquiera, incluso en las profundidades del pueblo y en el santuario femenino del hogar, puede intercambiar cualquier deseo por cualquier otro (Rancière, 2010, p. 81).

La democracia, el «reparto de lo sensible», corresponde al tipo de subjetividad agenciado por las nuevas tecnologías del poder ejercidas a través de la conducción de las conductas —la «excitación», las emociones nacidas a propósito de no importa qué y la avidez de poseer que reinan en la masa de individuos-. 
En los tiempos corridos desde la Revolución Francesa hasta el industrialismo, el Estado de gobierno se instaura y consolida como gestor de la conducta de la población. Al seguir a Foucault, se entiende el gobierno moderno no como la gestión del Estado, sino como las tecnologías mediante las cuales se ejerce el poder sin recurrir directamente a la violencia primaria de la fuerza para su funcionamiento. Esa tecnología da por objeto la conducta, lo cual quiere decir que tiene por medios la conducción de esta; la manera como se direccionan los hombres y por objetivo la dominación.

El gobierno puede considerarse como el punto de encuentro, móvil y asimétrico, de las técnicas de dominación de los otros con las técnicas de dominación de sí, es decir, el punto de vinculación de la conducción de los otros con la conducción que cada individuo hace de sí mismo. El término conducta refiere a la actividad de conducir algo, a la conducción; designa la manera como uno se conduce y la manera como uno se deja conducir; es la manera como uno es conducido y también el comportamiento bajo el efecto de una conducta, que sería el acto de conducta o de conducción. Tres aspectos se amarran en función de la constitución de la noción de gobierno: la manera como un individuo se conduce a sí mismo; la manera como el individuo mismo se deja conducir por otros; y la manera como es conducido por otros. A partir del siglo XVIII, el Estado de gobierno gestiona la conducta de los individuos en su vida cotidiana.

En un sistema político como aquel que se ha conocido en la Edad Media, el poder entendido bajo el sentido de gobierno de los unos por los otros era finalmente muy suave [...]. Lo que la gente hacía en su conducta cotidiana no era muy importante para ejercer el poder político. Pero, para el poder político ha venido un momento en que esto ha sido muy importante [...] (Foucault, 2012, pp. 240241).

La conducción de la conducta se opera, sobre todo, mediante la producción, recomposición, afirmación, de las maneras de vivir de los individuos, de su subjetividad o identidad. Si los individuos 
no hacen un juego positivo sobre sí mismos, a partir de todo aquello que el gobierno propone, promociona o prescribe, el gobierno sería imposible. Las tecnologías producen subjetividades «excitadas» sin poderse contener en sí, y objetos de excitación sin contención y en número ilimitado. No obstante, no se trata de procedimientos que nieguen la libertad de los individuos; por el contrario, el gobierno es posible en cuanto estos disponen de libertades excitantes. Su eficacia depende de las libertades y su eficiencia de la producción y consumo de libertad. Mas no de aquellas libertades que dependen de la ley o del derecho, o de un presunto contrato social; tampoco son aquellas libertades que emanan de una naturaleza humana universal, de una antropología. Las libertades que reclama y produce el gobierno son aquellas de tipo táctico y estratégico, que existen solamente en cuanto se ponen en juego frente a tal o cual acción y reacción. El gobierno es gestor y consumidor de libertades en función de la conducción de la población. Libertad y gobierno no son dos polos antitéticos, cada uno es la condición del otro: el ejercicio de la libertad es la condición para el ejercicio del poder y el poder es la condición para el ejercicio de la libertad. Táctico y estratégico, el gobierno en su ejercicio rueda sobre los juegos de unas conductas sobre otras conductas posibles, de una acción sobre otra acción posible: con tal acción se induce y se espera tal efecto; y con tal otra acción se responde al efecto inducido por la primera acción. El juego de la respuesta táctica es posible en cuanto que su agente dispone de diversas posibilidades de reacción, pues, de lo contrario, sería un golpe de fuerza. "Vivir en sociedad es de todas formas vivir de manera que sea posible actuar sobre la acción de los unos y los otros. Una sociedad sin "relaciones de poder" no puede ser más que una abstracción» (Foucault, 2001e, p. 1058).

En el siglo XIX, el gobierno es el primer gestor de las libertades de los individuos. A partir de fines del siglo XVIII, con el liberalismo, la producción de libertades ha devenido en una cuestión estratégica. Es necesario tomar el liberalismo no como corriente ideológica, ni bajo su pendiente económica: liberalismo 
es un tipo de práctica gubernamental que se determina no por respetar y garantizar tal o cual libertad, sino por ser productora y consumidora de libertad. Esta práctica gubernamental

[...] es consumidora de libertad en la medida en que ella no puede funcionar más que si hay efectivamente cierto número de libertades: libertad del mercado, libertad del vendedor y del comprador, libre ejercicio del derecho de propiedad, libertad de discusión, eventualmente libertad de expresión, etc. [sic] [...] el nuevo arte gubernamental consume libertad, es decir que está obligado a producirla [...]. El nuevo arte gubernamental se va a presentar entonces como gestor de la libertad, no bajo el sentido del imperativo: seas libre [...] sino que el liberalismo formula simplemente: yo voy a producirte con qué ser libre (Foucault, 2004, p. 65).

Conducta, subjetividad, libertad, son piezas mayores de la máquina del gobierno de los hombres. Así, «[...] hay dos sentidos de la palabra sujeto: sujeto sometido a otro por el control y la dependencia, y sujeto atado a su propia identidad por la conciencia o el conocimiento de sí [...]» (Foucault, 2001e, p. 1046). La práctica gubernamental produce su democracia de la sensibilidad, reparte lo sensible sin distinciones — «burgueses somos todos»-. Producida por agenciamientos, la subjetividad se reterritorializa en los individuos como su soberanía sobre el mundo, la vida, los otros. «La gente ligera, limitada, los espíritus presuntuosos y entusiastas quieren una conclusión de toda cosa; ellos buscan la meta de la vida y la dimensión del infinito [...]» (Flaubert, 1980, p. 718) ${ }^{36}$. El individuo toma la forma de sujeto fundador, y lo hace bajo el presupuesto de una antropología, una naturaleza humana, o un "yo», que existe en sí y por sí antes de toda experiencia posible. Flaubert manifiesta su repugnancia:

[...] yo creo en la evolución perpetua de la humanidad y en sus formas incesantes, odio todos los cuadros en los que se quiere a viva fuerza encerrar todas las formalidades de lo que se ha definido, 
todos los planes que uno sueña. La democracia no es su última palabra [...]. Así, buscar la mejor religión, el mejor gobierno, me parece una locura necia. Lo mejor para mí es aquello que agoniza porque hace lugar a otra cosa (pp. 718-719).

Sustrayendo las cosas de su movimiento, la bêtise moderna fija la última palabra, se apropia de las cosas e induce efectos de poder sobre los otros. Ahí, ¡Flaubert y su impaciencia! Comprime su repugnancia y la descomprime en un odio militante contra la bêtise moderna.

Yo me he aplicado a vivir en una torre de marfil. Pero una mareada de mierda golpea los muros, los hace crujir. No se trata de política, pero del estado mental de la Francia. (¿Usted ha leído la circular de Simón conteniendo una reforma de la instrucción pública?). El parágrafo destinado a los ejercicios corporales es más largo que el que concierne a la literatura francesa. He ahí un pequeño síntoma significativo (Flaubert, 1998, p. 605) ${ }^{37}$.

Casi tres años antes de morir, escribe:

¡Nuestro prefecto prohíbe las conferencias sobre Rabelais y sobre la geología! ¿Por qué? [...]. La bêtise humana actualmente me aplasta tan fuertemente que yo me hago el efecto de una mosca subiendo en el dorso del Himalaya. ¡No importa! Me aplicaré a vomitar mi veneno en mi libro (Flaubert, 2007, p. 309) ${ }^{38}$.

Flaubert resiste al poder que, bajo la legitimación antropológica, fija sus discursos de verdad, mengua la vida y la sustrae de las transformaciones: «[...] la mediocridad quiere la regla. Yo la odio. Siento contra ella, y contra toda restricción,

37 Epístola enviada a I. Tourgueneff el 13 de noviembre de 1872.

38 Epístola enviada a E. de Gncourt el 9 de octubre de 1877. En esta dirección, en epístola a E. De Goncourt, fechada el 22 de septiembre de 1874, Flaubert expleta: «iLa bestialidad moderna me espanta! ¡Ella crece día a día! ¿Adónde huir?» (Flaubert, 1998, p. 863). Por su parte, el 8 de diciembre de 1874 Sand escribe a Flaubert: «¡Cómo te atormentas y cómo te afectas con la vida! Pues todo de lo cual te quejas es la vida [...] tú amas demasiado la literatura, ella te matará y tú no matarás la bestialidad humana. Pobre querida bestialidad, que yo no odio, y que veo con ojos maternales, porque es una infancia, y toda infancia es sagrada. ¡Qué odio tú le has declarado, qué guerra tú le haces!» (Flaubert, 1998, pp. 894-895). 
corporación, casta, jerarquía, una execración que me llena el alma, y puede ser que por ese lado yo comprendo el martirio» (Flaubert, 1980 , p. 428$)^{39}$. Sin duda, la bêtise moderna se ejerce en todos los dominios de acción, en hombres vulgares e intelectuales, en el arte, la ciencia y la filosofía, en lo judicial, lo político y la religión, etc. El pujante capitalismo e industrialización del siglo XIX multiplica la estulticia, la dispersión, la diversión, la ligereza, las ilusiones y los dogmatismos. Despilfarro burgués de la vida. Cuando contaba con cincuenta y siete años, Flaubert dice de sí mismo en tercera persona: «[...] ahora él he [sic] llegado a tal punto de exasperación que cuando se encuentra con personas de esa especie [burgueses] siempre está tentado de estrangularlas, o mejor de precipitarlas en las letrinas [...]» (Flaubert, 2007, p. 364) ${ }^{40}$. Y unos pocos meses antes de su muerte, dice gravemente:

[...] yo he pasado dos meses y medio absolutamente solo, parecido a un oso de las cavernas, y en suma perfectamente bien, bien no viendo a nadie; ¡no he oído decir bestialidades! La insoportabilidad de la tontería humana ha devenido en mí en una enfermedad, y la palabra es débil. Casi todos los humanos tienen el don de exasperarme y yo no respiro libremente más que en el desierto (Flaubert, 2007, p. 797) ${ }^{41}$.

La observación atenta de los comportamientos de los individuos de su época, de las maneras de vivir de los hombres, de sus gestos, actitudes, actos, como si de libros se tratara, forman en Flaubert una disposición tan aguda como intolerable de la bêtise. En Bouvard y Pécuchet se lee: «[...] entonces una facultad lamentable se desarrolla en su espíritu, aquella de ver la bêtise y de no tolerarla» (Flaubert, 1979, p. 319). La bêtise moderna opera en Flaubert su actitud contra-cultural que se expresa, por un parte, en su obra crítica del êthos burgués del siglo XIx - hilo que conduce al tejido del capítulo cuatro de este trabajo-, y, por la otra, a proveerse a sí mismo de un modo de vida particular, 
que rompe con las promociones de su siglo - estos dos elementos conducen respectivamente el tejido del capítulo cuatro y tres de este trabajo-.

\subsection{Bêtise formidable}

A la bêtise moderna, fuente de la mayor impotencia del pensamiento y de la vida, se opone la bêtise formidable -llanura prosaica y montaña sagrada- - Sin embargo, la oposición es una relación vinculante, cada uno de los modos establece una relación de no relación con su opuesto, cada uno permanece resistiendo al otro, resistencia que resalta y afirma rasgos heterogéneos, sin síntesis posible, así como Flaubert contrapone la vida práctica y la vida contemplativa. A Sand, Flaubert le escribe: «[...] nosotros no sufrimos más que de una cosa: la Bêtise. Pero es formidable y universal» (Flaubert, 1998, p. 411 ${ }^{42}$. Deleuze retoma esa idea, da qué pensar ${ }^{43}$.

Hay un tipo de bêtise que, al rebasar todo nivel y todo orden empírico, se constituye en el trasfondo del pensamiento y en su condición de posibilidad. La bêtise acompaña y resiste al raciocinio como su revés. El pensamiento en su más elevada y pura abstracción, allá donde no hay categorías, no tiene otra forma más que de determinación, de diferenciación. Aquella, en esa misma dimensión, no tiene otro modo más que de indeterminación, de indiferenciación, lo impensado y lo no-pensante. Como un profundo fondo, «fondo sin fondo», la bêtise designa el umbral de movimiento de fuerzas sin determinación y sin categorías. Magma irracional sin particiones, sin distinciones, sin individuación. Al final de La tentación de San Antonio resuena la voz trémula del eremita: «Oh felicidad!, ¡felicidad!, yo he visto nacer la vida [...]. Yo quisiera [...] acurrucarme bajo todas las formas, penetrar cada átomo, descender hasta el fondo de la materia, — iser la materia!—»

\footnotetext{
42 Epístola enviada a G. Sand del 14 de noviembre de 1871.

43 Se retoman algunas de sus reflexiones las cuales, bajo responsabilidad, se llevan a otro camino $y$ con otros fines.
} 
(Flaubert, 1983, p. 237). Estas extasiadas palabras dejan sonar la existencia de la bêtise en sí y por sí, como una realidad ontológica antes de todo comienzo.

En otro escenario, en las conclusiones del proyecto de Bouvard y Pécuchet, los dos personajes se dicen a sí mismos: «[...] igualdad de todo, del bien y del mal, de lo bello y de lo feo, de lo insignificante y de lo característico [...]. Lo único verdadero son los fenómenos» (Flaubert, 1979, p. 443). Y en otra parte, en el fragmento de una carta dirigida a Maupassant, Flaubert (2007) escribe: «iUsted ha creído jamás en la existencia de las cosas? ¿Es que todo no es una ilusión? Lo único verdadero son las "relaciones", es decir, el modo mediante el cual percibimos los objetos» (p. 416) ${ }^{44}$. Los dos fragmentos des-realizan toda sustancialidad posible y el tipo de verdad inmanente a ella; la verdad es instaurada como relación, como modo de percepción; ontológicamente hablando, las cosas no existen, su existencia es una ilusión. Respecto a la verdad substancial, Flaubert (1980) atesta su escepticismo:

[...] a esta hora, yo creo igual que un pensador (¿y qué es el artista si no es un triple pensador?) En el presente me parece que la duda absoluta ha sido tan claramente demostrada que querer formularla sería casi una ingenuidad (pp. 316-317) ${ }^{45}$.

La verdad de la realidad es una ilusión del pensamiento, y la realidad de la verdad, una relación. Realidad y verdad son des-realizadas y des-antropologizadas. Si bien la verdad no existe ontológicamente, esto no implica que, bajo otro punto de vista, sea una pura nada. Hay lo verdadero que, sin existir, es la relación mediante la cual se perciben las cosas — que también son relaciones- No se trata de una relación sintética que presupone la existencia de un sujeto y de un fenómeno, a la manera kantiana; se trata multiplicidad de relaciones sin síntesis alguna. Las relaciones son acontecimientos, multiplicidades en movimiento 
que azarosamente se entrecruzan y se deshacen sin orden ni ley. Igualdad de todo, del bien y del mal, de la belleza y la fealdad, la verdad y la falsedad, de lo insignificante y de lo característico; todo es igual en cuanto relaciones; lo único verdadero son los fenómenos (cf. Flaubert, 1979, p. 443).

Agudo lector de Montaigne, Flaubert no confiere racionalidad alguna a lo real, el mundo se ensambla con cosas disímiles, sus movimientos son arbitrarios y sin teleología. Lo verdadero es un hecho histórico. La verdad no se vincula a lo originario, sino a su producción histórica, a aquello que Flaubert llama «sentido histórico» ${ }^{46}-\mathrm{y}$ sentido histórico del pensamiento y de la humanidad- La verdad es asumida no como adaequatio ni como certitudo, la verdad no es la correspondencia entre una representación, juicio, y la realidad; tampoco es la certeza de la verdad de lo real que comporta un sujeto; la verdad no es el conjunto proposicional que dice la verdad de la verdad de la realidad, ni tampoco lo que la explica o racionaliza. "Lo real es irracional y lo racional no es lo real». Lo real es bêtise; irracional es el movimiento y lo que hacen los hombres. Sin ser la soberana de su propio reino, la verdad es algo que, sin existir, induce efectos y marca las prácticas de los hombres bajo la impronta de las relaciones. En este modo de pensamiento, ni la idea de causas ni la idea de progreso de la humanidad tienen lugar, cada época produce lo suyo.

Esta manía de creer que se viene de descubrir la naturaleza y que se es más verdadero que los antecesores, me exaspera. La Tempestad de Racine es tan verdadera como la de Michelet. No hay lo verdadero ¡No hay más que maneras de ver! (Flaubert, 2007, p. 811$)^{47}$.

46 «El sentido histórico es completamente nuevo en este mundo. Uno se va a poner a estudiar las ideas como los hechos, y a disecar las creencias como los organismos» (Flaubert, 1991, p. 16). 47 Epístola enviada a L. Henrique del 2 de febrero de 1880. 
El mundo fluye sin determinación, sin finalidad. Transformación de relaciones. Flaubert enfoca la movilidad perenne de las cosas en la humanidad. Solo la gente ligera, limitada, presuntuosa, apasionada, quiere concluir siempre sobre cada cosa: «[...] ningún gran genio ha concluido y ningún gran libro concluye, porque la humanidad misma está siempre en marcha y porque ella no concluye» (Flaubert, 1980, p. 718). La epoché juega su papel en el pensamiento de Flaubert como suspensión de cualesquier conclusiones. Las ideas son hechos históricos, cosas fabricadas; y la vida y la historia son un eterno problema. Así, la cuestión no es estudiar si tal idea dice la verdad del mundo o si tal es falsa, sino examinar la constitución de la idea como idea: «[... yo observo mucho y no concluyo jamás, medio infalible para no engañarse...» (Flaubert, 1973, p. 363) ${ }^{48}$. La verdad de la verdad es el hecho de la construcción de la relación, su valor se fija por la manera de la composición por su rigor y profundidad, por la manera de ver el aparecer de las visibilidades. Mas «[...] no importa, el escepticismo no tendrá nada de amargo» (Flaubert, 1980, p. 718$)^{49}$.

Si bien, en La tentación, el eremita quiere ser la materia bajo todas sus formas, la bêtise de la materia, no se ha de desconocer que toda La tentación es la noche delirante de San Antonio. Los delirios están en el pensamiento del buen eremita, tal como el diablo se lo dice al final de la primera versión de la obra: «[...] los pecados están en tu corazón y la desolación rueda en tu cabeza» (Flaubert, 1908, p. 530). Bajo otra formulación, en la última versión, se encuentra la misma idea cuando el mal discípulo Hilarión, que el eremita cree que lo ha abandonado mucho tiempo atrás (y que luego se transformará en un diablo filosófico y espinosista), le dice que nunca lo ha abandonado, porque siempre ha estado en él. Ontológicamente, el ser sin determinación, en su plena brutalidad de movimiento, es un delirio, una ilusión del pensamiento que tienta al pensamiento. El pensamiento se tienta a sí mismo (guardemos esto).

48 Epístola enviada a L. de Chantepie del 18 de mayo de 1857.

49 Epístola enviada enviada enviada a L. de Chantepie del 18 de mayo de 1857. 
Ontológicamente, la bêtise es una ilusión, mas como relación será un modo de percibir. Si el pensamiento en su más elevada abstracción solo es determinación, allá, la bêtise solo podría ser indeterminación de las relaciones del pensamiento, es decir, una absoluta relación de no-relación. Se conoce que el pensamiento no es una facultad natural inherente a una naturaleza humana, sino relación de relaciones, o mejor, una relación inherente a unas relaciones de relaciones; por tanto, se puede considerar que la bêtise - lo indeterminado- es el revés de la relación de relaciones -lo determinado-. La bêtise es el diablo metafísico de la filosofía.

En Diferencia y repetición, después de retomar la conocida expresión, "lo que más nos da a pensar es no pensamos todavía» pronunciada por Heidegger en su seminario ¿Qué significa pensar? Deleuze (2011) amarra la bêtise a ella y dice:

[...] es necesario que el pensamiento, como determinación pura, como línea abstracta, afronte ese sin fondo que es lo indeterminado [...]. La bêtise (no el error) constituye la más grande incapacidad del pensamiento, pero también la fuente de su más alto poder respecto a aquello que lo fuerza a pensar (pp. 352-353).

El pensamiento piensa en cuanto algo, resistiéndole, lo fustiga a pensar. La resistencia intensiva y la amenaza mayor del pensamiento cuando piensa no es el error, la equivocación; puesto que, de alguna manera, el error es un efecto de un acto categorial del pensamiento, el error cuando aparece ya está inscripto en el interior de las categorías del pensamiento, es un mal uso de las categorías. Lo que resiste eminentemente al pensamiento es la bêtise, la relación de no relaciones. En su más elevada abstracción, el pensamiento está abocado a enfrentarse con esa resistencia, su revés que amenaza con borrarlo. Pero, si la bêtise fuera solamente una negación ¿cómo resistiría y obligaría al pensamiento a pensar? Ella es la fuerza de la relación de no relaciones, es el poder de no..., expresión eminente de la potencia del pensamiento. La bêtise es un tipo de uso del poder pensamiento que, de manera absoluta, 
hace inoperosa la potencia del pensamiento. La oscuridad de esta afirmación se aclara con la luz que ofrece el trabajo de Agamben.

\subsubsection{Uso inoperoso}

El concepto de uso dispone el pensamiento de otra manera. La cultura occidental en su historia no ha cesado de desplegar el pensamiento en relación con la poiesis y la praxis. Agamben, en su trabajo arqueológico, sitúa su concepto de uso en relación directa y constante con Aristóteles (como se trató en el capítulo I). Poiesis y la praxis - la acción que tiene su fin en la obra y la acción que tiene su fin en sí misma- remiten a los conceptos de potencia y acto - ser en obra- y, desde luego, a los problemas de su emergencia. Conocido es que potencia y acto se oponen, lo que está en potencia no está en acto y viceversa; mas se trata de una oposición vinculante y sostenida (Agamben, 2016). Cuando Aristóteles habla de la potencia (dynamis) no se refiere a una potencia genérica como cuando se dice que un niño está en potencia de ser arquitecto, o flautista, o zapatero, pues de ser así, el concepto se esfumaría quiméricamente.

La potencia siempre es de algo y de alguien, por ejemplo, la potencia de arquitecto la posee solamente quien es arquitecto. La potencia del arquitecto se diferencia de su enérgeia, de estar en acto, y se diferencia en cuanto que, en tal modo del ser, el arquitecto tiene la potencia de construir sin construir. Pero, si la potencia fuera solo potencia de construir, ¿cómo podría sostenerse como potencia, sin pasar directamente al acto? Debe haber algo en el interior de la potencia misma que resiste para que exista y se sostenga como dynamis sin devenir en acto. Si la potencia fuera solo del poder de construir caería ipso facto en el acto de construir, no se podría distinguir entre dynamis y enérgeia.

En el interior mismo de la potencia del arquitecto, se envuelve el poder de no construir. Solo quien es arquitecto tiene el poder de construir y el poder de no construir; la potencia es potencia de... 
y a la vez potencia de no... Es esa potencia de no... que resiste a la enérgeia y sostiene la potencia. Lo que está en potencia no es ser-en-acto, no está en obra, y viceversa, sin embargo, no se ha de desconsiderar que cuando el arquitecto construye y el escritor escribe, cuando se produce el pasaje de la potencia al acto en la producción de la obra, sigue subsistiendo, subsiste, permanece, la potencia del arquitecto y del escritor. Así, la obra no es solamente el testigo del poder de..., en ella está la presencia del poder de... y del poder de no..., presencia de la potencia.

Si toda potencia es tanto potencia de ser como potencia de no ser, el pasaje al acto sólo [sic] puede advenir transportando al acto la propia potencia-de-no. Eso significa que, si a todo pianista pertenece necesariamente la potencia de tocar y la de no tocar, Glenn Gould es, sin embargo, el único que puede no no tocar y, dirigiendo su potencia no sólo [sic] al acto sino también a su propia impotencia, toca, por así decirlo, con su potencia de no tocar. Frente a la capacidad, que simplemente niega y abandona su propia potencia de no tocar, y frente al talento, que puede sólo [sic] tocar, la maestría conserva y ejercita en el acto no su potencia de tocar, sino la de no tocar (Agamben, 2016, p. 40).

Siempre en uso, la potencia de no... resiste agónicamente a la potencia de..., mas en el acto, no se podría decir que efectivamente la resistencia ha sido eliminada. La maestría de Glenn Gould, en el ejemplo que da Agamben (2016), comporta siempre su propia impotencia: solo él puede no no tocar (quien no sabe tocar piano cómo podría no tocar o no no tocar). "Quien carece de gusto no logra abstenerse de algo; la falta de gusto es siempre un no poder no hacer» (p. 41). Tal podría ser también el caso de una conocida imagen del pensamiento de Blanchot: el escritor está frente a su hoja de papel, ya lista en la máquina de escribir; y ella permanece en blanco, ¿Por qué no puede llenarla? No precisamente porque no tiene nada que escribir, sino porque la página ya está repleta de relaciones-cliché. Solo quien tiene la potencia del escritor puede percibir el exceso que se insinúa; y solo quien tiene la potencia de escribir, escribe con su poder de no no-escribir. El poder de no... 
es la potencia la cual se «hace pedazos en la obra la pretensión de la apariencia de totalidad», es decir que la impotencia de... hace que la potencia de... no se agote en el acto, que la obra no pueda alcanzar su absoluta perfección. La impotencia de... es la instancia crítica, lo que pone e impone que la obra podía no ser o podía ser de otra forma, es decir, su contingencia, siempre inacabada, dispuesta a otros usos posibles. Más allá del sentido común, la maestría en cualquier dominio del pensamiento consiste en «... la conservación de la potencia en el acto, salvación de la imperfección en la forma perfecta [...] la resistencia de la potencia-de-no se imprime en la obra como el íntimo manierismo presente en toda obra maestra» (Agamben, 2016, pp. 40-41).

En la determinación de la relación de las relaciones que ha deseado componer el autor de una obra, subyace su imperfección. Mas, la imperfección no es una carencia, sino una sobreabundancia, un exceso de relaciones que, resistiendo al pensamiento, se adicionan a la relación creada, a la determinación de la relación que el pensador ha querido plasmar en su obra. Flaubert hace su obra de arte de escritura La tentación de san Antonio; la lee a sus amigos en 1849, mas su última versión data de 1872. Sus trazos arqueológicos datan de 40 años atrás, se sitúan en los grafismos de sus los escritos de juventud; Flaubert la reconoce como la obra de su vida. La primera versión de esta obra, por ejemplo, en su contingencia, comporta un exceso de relaciones que contaminan la relación que el pensamiento quiere determinar.

Flaubert ve la fragilidad de su obra, las grietas, lo que no puede alcanzar en esta. En esa situación, ¿qué hace el artista? Rehace su obra; y seguidamente ve que otra vez la grieta no está llena; y cuantas veces rehace su obra, la grieta vuelve aparecer. Antes de terminar la primera versión de La tentación, Flaubert la corrigió, mas su sobreabundancia era de tal magnitud, que habría de hacer una segunda versión, que correría con un destino igual. Entonces tuvo que hacer una tercera que, antes de cerrarla, 
también corrigió e intervino en su exceso. La grieta no está llena, esta es fractura que separa dos partes y, al separarlas, las acerca. Sin existir, la grieta no es una ausencia, sino una relación de la no-relación hecha visible. La grieta acerca y separa dos cosas distintas: la idea que el pensamiento quiere determinar, la idea de la relación determinada de relaciones que sería la obra, y lo que es la obra (la sobreabundancia efectiva de relaciones adicionadas a la idea).

Considerando las relaciones categoriales del pensamiento y sus composiciones, cuestionando los saberes modernos, sus inferencias, sus instauraciones y sus instituciones, interrogando el pensamiento desde la vida y el mundo y examinando sus producciones; Flaubert bordea los contornos del pensamiento. Redoblando la producción del pensamiento sobre el pensamiento, hace que se refleje sobre sí mismo, como un rostro en un espejo, y ahí, obliga al pensamiento a tocar sus propios límites. Tal vez en La tentación de san Antonio y en Bouvard y Pécuchet no hacía otra cosa. Un pensamiento del pensamiento que, dejando en suspenso su obra, hace gravitar el pensamiento y que, dejando en suspenso al pensamiento, hace gravitar su obra como uso del poder de pensar y del poder de no pensar. La potencia del pensamiento está constituida por el poder de pensar, de determinar, diferenciar, y por el poder de no pensar, indeterminar, indiferenciar, es decir, por la bêtise. En los límites de la obra, la bêtise insinúa sus trazos como aquello que resiste a la perfección absoluta de la producción. La tentación de la bêtise ha existido no solamente en todos los libros de Flaubert, sino también en toda la experiencia de su propio pensamiento; y como acto, en el ensayo de pensar sus ideas y sus preocupaciones existenciales.

Pero, si la potencia envuelve tanto el poder de... como el poder de no..., si la potencia se sostiene como tal solo en cuanto se diferencia del acto, ¿cómo se opera el paso de la potencia al acto? Agamben (2017) ha mostrado que Aristóteles tiene que 
recurrir a otro elemento, es decir al hábito, el cual se constituye en el operador del paso de la potencia al acto; sin embargo, el problema no se resuelve, su complejidad se duplica.

El concepto de hábito [héxis] había sido pensado por Aristóteles precisamente para eliminar las aporías implícitas en esta doctrina $\mathrm{y}$ asegurarle a la potencia alguna realidad. Si el ser (el uso) se escinde en potencia y acto, se necesitará, en efecto, algo que articule y haga posible el pasaje de una al otro. Si la potencia fuese siempre y solo potencia genérica, como aquella, puramente quimérica, que compete a un niño del cual decimos que podrá volverse escritor o carpintero o arquitecto o flautista, entonces el concepto de potencia se disolvería y su puesta en obra se volvería impensable. El hábito es aquello que torna posible el paso de la potencia desde la mera generalidad hacia la potencia efectiva [...]. Es decir, el hábito es la forma en la cual la potencia existe y se da realidad como tal. Las aporías de la potencia genérica, que de este modo son neutralizadas, sin embargo, se reproducen enseguida en la nueva realidad que ella se ha dado. Para que se pueda mantener una distinción entre el hábito y el ser-en-obra, para que la héxis no se convierta ya ciegamente en enérgeia, es de hecho necesario que quien posee el hábito de una técnica o de un saber pueda no ejercitarlo, pueda no pasar al acto. Por esto en el libro IX de la Metafísica, la tesis decisiva sobre la potencia-hábito dice: "toda potencia es impotencia de lo mismo y según lo mismo" [...] (Metafísica 1046 a 30). La ambigüedad de la noción de "potencia de no" aquí aparece con claridad: es lo que permite al hábito darse existencia como tal y. al mismo tiempo, es constitutivamente inferior al acto al cual está irrevocablemente destinada [...] pero la enérgeia, el ser-en-obra, sigue siendo la finalidad de la potencia. No obstante, de este modo, la aporía que había creído eliminar reaparece de forma aún más aguda: si a toda potencia-hábito le es irreductiblemente inherente una potencia de no pasar al acto, ¿cómo será posible determinarla a este pasaje, ¿cómo será posible despertarla del sueño? (pp. 122-124).

En este punto, en la aporía aristotélica, Agamben (2017) encuentra el lugar propio para introducir el concepto de uso. Para él, en primer lugar, Aristóteles habría escindido el uso 
en dynamis y enégeia, y a partir de ahí, entre hábito y ser-enobra. Esto se reafirma cuando se considera que, en las obras de juventud, Aristóteles había empleado el término chrêsis (uso) en un sentido similar al que daría al concepto de enérgeia; por ejemplo, en el Protréptico define la filosofía como «posesión y uso de la sabiduría». Agamben, en primer lugar, acoge la tesis según la cual la oposición entre dynamis y chrêsis, ser en potencia y ser en uso, proviene de Platón; del Eutidemo, donde se distingue la posesión de una técnica y de los instrumentos apropiados sin servirse de ellos y su empleo en acto. Aristóteles posiblemente habría comenzado, con la diferenciación entre poseer una ciencia y usarla, para luego sustituir el término de chrêsis por uno de su invención, que no conocía - por supuesto- Platón, el término de enérgeia, ser-en-obra. En segundo lugar, ensaya resolver la aporía de Aristóteles, al retomar el término chrêsis, al hábito, y expresar:

Solo si pensamos el hábito no únicamente en modo negativo - a partir de la impotencia y de la posibilidad de no pasar al acto- sino como uso habitual, la aporía, en la cual naufragó el pensamiento aristotélico de la potencia, se disuelve. El uso es la forma en la cual el hábito se da existencia, más allá de la simple oposición entre potencia y ser-en-obra (Agamben, 2017, p. 124).

Agamben opone el concepto de uso a la tradición aristotélica, que culmina en la escolástica y deja su legado en la historia de la cultura occidental que se sigue. La escolástica hace del término uso un sinónimo de enérgeia, lo que implica su separación tajante del hábito o la potencia. Al respecto, Agamben (2017) sostiene:

"Uso - escribe Tomás- significa el ser-en-acto de cualquier hábito [usus significat actum cuiuslibet habitus]. El acto de un hábito cualquiera y el uso de la potencia pertenecen a aquel (o aquello) al cual le pertenece el acto; por esto el término uso significa el acto y de ningún modo la potencia o el hábito". Contra esta tradición, es necesario pensar el ser-en-uso como distinto del ser-en-acto y, a la vez, restituirlo a la dimensión del hábito, pero de un hábito que, en cuanto se da como uso habitual y está, por 
consiguiente, siempre ya en uso, no presupone una potencia que deba, en un determinado momento pasar al acto, ponerse en obra (p. 121).

Frente a la tradición que homologa el uso al acto y distingue el acto de la potencia o el hábito, se diferencia el ser en uso del ser en acto. Esta operación permite desactivar la oposición entre potencia o hábito y uso. Así, el hábito siempre está en uso y nunca en un estado de potencia que habría de tender a su finalidad y alcanzar su perfección en el acto, en la obra. De este modo, el pasaje de la potencia al acto resulta tan inútil como impertinente: el uso siempre está en uso, el hábito o la potencia siempre está en acto, en obra. Desde este punto de vista, la obra no es el resultado del tránsito de la potencia o del hábito al acto que la produce, sino que en la obra está presente la potencia y el hábito que no dejan de relanzar la obra hacia otros usos posibles. La presencia actual de la potencia es la condición para que en la obra se pueda contemplar la potencia y el hábito que la produce. En la obra, esta se torna re-flexiva y se hace el espejo en que ella misma se contempla a sí misma. Si la obra deviene en lugar propio de la contemplación, entonces se ha de conceder que, ahí, en ella, el acto de producción no tiene su finalidad en algo externo - que sería la obra-, sino, que acto y obra se identifican bajo el uso. El uso deviene «inoperoso», se torna en contemplación de la potencia y de hábito; la obra, opus, pierde su connotación de obra como lo opuesto a la potencia, ella abre a la presencia de la potencia «inoperosa», la cual está en uso, que siempre ha sido uso, ser-en-uso.

Agamben (2017) desactiva la oposición potencia/acto; la potencia siempre está en acto y, a la vez, el acto siempre está dispuesto y puesto en juego en la potencia. "El uso es la forma en la cual el hábito se da existencia, más allá de la simple oposición entre potencia y ser-en-obra» (p. 124). Y, unas páginas más adelante, considera: 
¿Qué es el uso habitual, cómo se usa un hábito sin hacerlo pasar al acto, sin ponerlo en obra? Está claro que no significa inercia o simplemente ausencia de obras, sino una relación por completo distinta de ellas. La obra no es el resultado o el cumplimiento de una potencia, que se realiza y agota en ella: la obra es aquello en lo cual la potencia y el hábito están siempre presentes, siempre en uso, es la morada del hábito, que no deja de mostrarse y casi danzar en la obra, incesantemente reabriéndola a un nuevo uso posible (p. 128).

Ahora retornemos a nuestra bêtise, siguiendo la línea de fuga posible que abre el concepto de uso de Agamben. Danzando en la obra, "inoperoso» es el pensamiento cuando, en las conclusiones de Bouvard y Pécuchet, los dos personajes bestiales dicen: “¿Qué vamos a hacer?” - ¡No reflexión! ¡Copiemos! Es necesario que la página se llene, que "el monumento [de la bêtise]» se complete"» (Flaubert, 1979, p. 443). El pensamiento permanece en su plena y perfecta betise. Esta es formidable: el uso del poder de no pensar reabre la puerta al mayor uso posible de la potencia del pensamiento. Recordemos - siguiendo a Deleuze- que la bêtise constituye la más grande incapacidad del pensamiento y también que la bêtise constituye la fuente de más alto poder del pensamiento. Si la fuerza de la bêtise torna el pensamiento absolutamente inoperoso, también ella lo abre a un nuevo uso en el que alcanza su mayor poder: la contemplación.

\subsubsection{Contemplación}

La presencia de la potencia-poder de... y poder de no...-en la obra, la reabre a nuevos usos. La mayor expresión de la potencia y el hábito en su mostrarse, en el reabrir la obra a otro uso, se cumple en la contemplación de la potencia, que hace «inoperosa» la enérgeia y las obras que afloran en ella. «[...] es el paradigma del uso» (Agamben, 2017, p. 129). «Inoperosa», la contemplación deviene en el uso eminente de la potencia cuando esta se contempla a sí misma. En el uso contemplativo de sí misma, la potencia no contempla otra cosa que su poder de... y su poder de no... En 
uso, la contemplación no será otra cosa que la contemplación de los usos posibles de la potencia del pensamiento. Ahí, en el uso contemplativo de sí misma, la potencia del pensamiento no corresponde al orden de las categorías, ni del conocimiento, ni del juicio; la potencia es plenamente «inoperosa». En la contemplación, la «inoperosidad» de la potencia del pensamiento en uso, el pensamiento se sostiene y se con-tiene en sí mismo.

En el uso eminente de la potencia del pensamiento, en la contemplación, no diremos que Flaubert tiene una potencia y un hábito —una disposición, hexis—, sino que, efectivamente, esa potencia y ese hábito hacen el pensador. El pensador es el propio uso de la potencia y el hábito de pensar, mas se trata de un uso instituyente. El pensador no es el sujeto soberano que posee una potencia y un hábito, que luego, por su propia voluntad, haría pasar al acto de pensar, al ser-en-obra - como Dios cuando, por sí y en sí, y por su omnipotente voluntad, crea el mundo de la nada- - El ser en uso de la potencia y el hábito de pensar borra toda referencia a una voluntad soberana como a un sujeto fundador: «[... la voluntad es, en la cultura occidental, el dispositivo que permite atribuir las acciones y las técnicas en propiedad a un sujeto [...]» (Agamben, 2017, p. 127). El pensador no es el titular de una potencia y un hábito, sino quien haciendo experiencia del pensamiento se instaura en el «usante» de sí mismo, en el «usante» de la potencia del pensamiento. El uso de la potencia del pensamiento se opone a toda antropología arrogante que, fija el Hombre, o la naturaleza humana, o el «yo» como sujeto soberano, fundador y tenedor de la verdad del mundo y la humanidad. El uso borra las posibilidades de toda antropología, y de los efectos que induce. Flaubert, piensa efectivamente sin antropología, sin sujeto. El uso de la potencia del pensamiento no se distingue del «usante» de sí mismo. Agamben escribe:

La contemplación es el paradigma del uso. Del mismo modo que el uso, la contemplación no tiene sujeto, porque, en ella, el contemplante se pierde y resuelve integralmente como el uso, la contemplación no tiene un objeto, porque, en la obra, contempla 
solamente la (propia) potencia. La vida, que contempla en la obra la (propia) potencia de obrar o de hacer, se vuelve "inoperosa" en todas sus obras, vive sólo [sic] en el uso de sí, vive solo la (su) vivibilidad. Escribimos "propia" y "su" entre paréntesis porque únicamente a través de la contemplación de la potencia, que vuelve inoperosa toda enérgeia y toda obra, algo como la experiencia de un "propio" y de un "sî" se vuelve posible. El sí mismo - cuyo lugar usurpará el sujeto moderno- es lo que se abre como una inoperosidad central en toda la operación, como la "vivibilidad" y la "usabilidad" en cada obra. Y si el arquitecto y el carpintero siguen siendo tales incluso cuando no construyen, esto no es porque ellos son titulares de una potencia de construir, que pueden hasta no poner en obra, sino porque viven habitualmente en el uso de sí como arquitectos o carpinteros: el uso habitual es una contemplación y la contemplación es una forma de vida (Agamben, 2017, p. 129).

En Flaubert, de manera radical, el uso de la potencia del pensamiento se instaura en contemplación y la contemplación en una forma de vida, modo que él llamará vida contemplativa, en oposición a la vida práctica o activa. Mas también el uso de la contemplación llegará a definir e instaurar su concepción de estilo en la obra de arte de escritura. Como un sentimiento religioso, la contemplación sustrae la vida de la dimensión práctica, activa, productiva: «[...] sin el amor de la forma, puede ser que yo hubiese sido un gran místico» (Flaubert, 1980, p. 218). Escéptico, sin Dios, sin fe y sin creencia, con su bêtise y su sentimiento grave, Flaubert hace del uso de la contemplación un precepto y una forma de vida: «Seamos religiosos [...]. Yo giro a una especie de misticismo estético (si las dos palabras pueden ir juntas)» (Flaubert, 1980, p. $151)^{50}$.

La idea de una vida contemplativa como admiración y conocimiento desinteresado de la verdad y del mundo se haya en Aristóteles -él da, por ejemplo, la vida de Tales-. Por otra pendiente histórica, dicha idea respecto a Dios, cuyo extremo

50 Epístola enviada a L. Colet del 4 de septiembre de 1852. 
límite es el misticismo, es introducida y difundida ampliamente por el cristianismo. Mas la idea de una vida contemplativa de la belleza y un misticismo estético, son una composición inédita en la cultura occidental. El misticismo estético como forma de vida del artista es el uso de la potencia del pensamiento en su más elevada perfección; contemplación de la belleza, de la belleza de la potencia del pensamiento, de su poder de pensar y de no pensar. Y ahí, para Flaubert, «El estado ideal resultante de esta alegría me parece una especie de santidad, que puede ser más elevada que la otra porque es más desinteresada» (Flaubert, 1980, p. 698) ${ }^{51}$.

Al concluir este segmento, se puede decir que, en Flaubert, la vida artista se instaura en una experiencia histórico-crítica de la vida o de la bêtise. La estupidez moderna se dispone como materia de una elaboración existencial que conlleva a la construcción de un modo de vida que asegure la tranquilidad que la cultura del siglo xix le niega. En su trabajo sobre la bêtise, Flaubert alcanza la mayor fuente de poder del pensamiento, la contemplación del poder de pensar y del poder de no pensar; logro que le permite el despliegue de un misticismo estético. Sin embargo, su sensibilidad y sus afecciones disponen, por otra parte, una actitud militante contra el modo de ser promocionado por la cultura de su siglo. Allí se encuentra la fuente de su obra de arte de escritura con la cual ejerce una función contra-cultural. La bêtise puede considerarse entonces como un operador estético-crítico que conlleva a la creación de una moral estética - capítulo tres - y a la creación de una obra que, en su veridicción, eminentemente pretende inducir efectos críticos en la cultura del siglo xIx — capítulo cuatro-.

51 Epístola enviada a L. de Chantepie del 30 de marzo de 1857. 


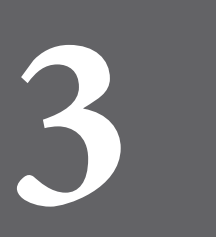

CAPÍTULO TRES 



\section{Moralis aesthetica}

Yo he dicho un irrevocable adiós a la vida práctica. Mi enfermedad de nervios ha sido la transición entre esos dos estados. No reclamo de aquí a largo tiempo más que cinco o seis horas de tranquilidad en mi habitación, un gran fuego en invierno y dos velas cada noche para alumbrarme (Flaubert, 1973, p. 718) ${ }^{52}$.

Cuando escribe esas líneas, Flaubert cuenta con veintitrés años y una necesidad existencial lo habita. Más importante que el importante oficio del arte, la idea de una tranquilidad sencilla se insinuaba confusamente desde tiempo atrás en la bruma de su melancolía eminente. Una idea clara lo alumbra una década después:

[...] la felicidad o lo que se le aproxima está compuesta de pequeños bienestares, lo mismo que la no-desgracia no se obtiene más que por la plenitud de un sentimiento único que nos tapa las aberturas del alma a todos los accidentes de la vida (Flaubert, 1980 , p. 551) $)^{53}$.

52 Epístola enviada a A. Le Poittevin del 13 de mayo de 1845.

53 Epístola enviada a L. Colet del 18 de abril de 1854. 
En los dos tiempos de la frase, el pensamiento deshace la ecuación felicidad - no desgracia-. El primer miembro se compone de la suma de pequeños accidentes heterogéneos de la vida común que entran en el alma desde el exterior. En la felicidad $-\mathrm{y}$ sus parientes-, el alma es inactiva, está dispuesta, sin resistencia, a recibir los efectos inducidos por un número de pequeñas contingencias. La felicidad es una «pasión inactiva» del alma. Menesterosa, menguada, humillada, el alma es mendiga de bienestares. El segundo miembro es un logro del alma que alcanza a través de la mediación de la perfección de una disposición hábito en uso- que, propia e interior, le permite con-tenerse en ella misma. Plétora de sí en el uso de sí misma, el alma está encerrada en su propia habitación, ninguna cantidad contingente se adiciona a su valor. La felicidad se compone de lo que no depende de uno; la no desgracia se obtiene mediante lo que depende de uno mismo. Cuando Flaubert contaba con cincuenta y tres años, atestó: «[...] después de mi juventud, he sacrificado todo por mi tranquilidad de espíritu [...]» (Flaubert, 1998, p. 946) ${ }^{54}$. Preceptos estoicos residen en su pensamiento. Desde tiempo atrás, Flaubert había reflexionado: «[...] ¿quién sabe entonces si no habría medio de encontrar a través de la estética lo que el estoicismo había inventado para la moral?» (Flaubert, 1980, p. 76) ${ }^{55}$.

Entra en juego la moral estoica, un estilo de vida y no su doctrina metafísica. ¿De qué modo, es decir, disponiendo qué materia a transformar, bajo qué principio y condiciones, buscando qué fin, con qué herramientas y técnicas, Flaubert busca en la estética la tranquilidad estoica del alma? Construir unas respuestas posibles a estos interrogantes es el propósito de este capítulo. Los análisis de estas cuestiones se abordarán esquemáticamente por fines explicativos, sin desconocer sus imbricadas relaciones.

54 Epístola enviada a G. Sand del 18 de agosto de 1875 . 55 Epístola enviada a L. Colet del 24 de abril de 1852. 


\subsection{Principio estético}

El «uso» habitual de la bêtise se instaura como materia de preocupación del pensamiento y la existencia de Flaubert. Un principio estético-moral conduce esa preocupación. La reflexión moral de la vida-artista no apunta a establecer un código sistemático que, como un deber exterior, fijaría las maneras de vivir, trazaría las fronteras de prohibiciones y permisiones, sino que tiende a elaborar las condiciones y las modalidades de la conducción de la existencia. Más que fijar unas reglas de conducción, Flaubert ajusta la relación que sostiene consigo mismo y con los otros —o el uso de sí mismo-, a un principio conductor: la belleza. La vida se pliega sobre la belleza, su punto de inflexión. ¿Cuál es el estatuto de ese principio, qué tipo de validez le reconoce Flaubert para justificar su aceptación? La belleza deviene en el modo estético y moderno del antiguo principio de preocupación de sí mismo, como conductor del uso de sí mismo, de la forma de vida. Este principio de conducción se perfila en la vinculación de la verdad del arte con algunos preceptos morales del estoicismo. El principio de preocupación de sí mismo, devenido en principio filosófico, en precepto de vida, en práctica, en un modo de vida filosófica, tras muchos avatares a lo largo de la historia de la cultura occidental ha jugado un papel mayor y fundamental en la constitución de las relaciones que nosotros tenemos con nosotros mismos, en la construcción de nuestro êthos (Foucault, 2017, pp. 35-36). Precisemos este punto.

El legendario principio «preocúpate de ti mismo» designa la preocupación por la vida. Constituye el subsuelo arqueológico de la moral y la ética de la cultura occidental. Los héroes de Homero se conducen por el principio de hacer de su vida una obra brillante, cuyos valores fundamentales son la areté y lo memorable. Conducido por su areté, por la preocupación de dejar a la posteridad un nombre memorable, Aquiles ha de matar a Héctor pagando el costo de su heroísmo trágico; Ajax ha de limpiarse de la vergüenza de su locura suicidándose; Odiseo, «el eterno marido», 
ha de recuperar Ítaca, su mujer y su hijo, tras diez años de avatares. Desde Homero hasta el siglo v a. C., el principio de la preocupación de sí mismo desborda cada experiencia de la cultura y las recorre todas, se expresa en la poesía y la política, en sectas y rituales, en los templos y los oráculos, etc. ${ }^{56} \mathrm{La}$ preocupación de sí era un ideal social altamente valorizado, extendido y practicado. Antes de la irrupción de la filosofía ya se había constituido en precepto, práctica, forma de vida. La filosofía irrumpe apropiándose e instaurando en su propio interior el principio de preocupación de sí como actitud y actividad y fijándolo en su razón de ser. Ella se sostiene como precepto y tecnología, disposición, y praxis del legendario principio (Foucault, 2017).

En el amor a la verdad, la vinculación de la preocupación de sí y la preocupación de la verdad es capital. La filosofía lo pliega sobre la verdad como su línea de inflexión. La preocupación de sí se instaura en la imagen de verdadera vida: preocupación de la vida de la verdad, en la verdad, por la verdad, para la verdad. Dos nódulos disímiles se amarran e instauran dos líneas de fuga mayores del pensamiento de Occidente: estilo de vida y discurso de verdad. En la antigüedad grecolatina, entre las sectas de los amigos de la verdad, el peso conferido a cada uno de esos núcleos como también sus maneras de vinculación son disímiles. Por ejemplo, el estoicismo romano se aplica más a la cuestión de los estilos de vida que a la doctrina de la verdad (que la recoge y la hace operar en una serie de axiomas o dogmas), a diferencia del estoicismo griego - el de Crisipo o el de Zenón- donde es a la inversa. En el caso particular del cinismo, la doctrina es casi inexistente, queda reducida a uno pocos principios, mientras que el despliegue extremo del estilo de vida no tiene igual en otras sectas. El cinismo se instaura casi como pura moral, puro estilo de vida. En la historia del pensamiento occidental, cada uno de los dos núcleos ha corrido, se podría decir, con independencia. En

56 Varios historiadores de la antigüedad, entre ellos Doods y Vernant, han mostrado que el legendario principio de la preocupación de sí - acompañado de un conjunto significativo de prácticas éticas- entró muy tempranamente en la aurora de la cultura griega procedente de culturas orientales (cf. Foucault, 2017, p. 35). 
algunos casos, una determinada doctrina de la verdad se sostiene y se amarra con diversos estilos de vida y viceversa, por ejemplo, la metafísica del alma platónica amarrada con un estilo de vida cristiano. En el caso del estoicismo en particular, el modo de vida llega a Flaubert, mas no su doctrina metafísica; y antes ha pasado por el Renacimiento amarrándose con doctrinas metafísicas distintas. Flaubert se interesa, valora y retoma el núcleo estoico del estilo de vida, mas no su doctrina de la verdad, que no solamente no tiene espacio en su pensamiento, sino que también resulta contradictoria con su moderno «sentido histórico» de reciente invención.

Ahora bien, en el estudio de los estilos de vida, de la construcción controlada y dirigida de la subjetividad, hay que tener en cuenta otro acontecimiento: la transformación de las tecnologías de la subjetividad efectuada por el cristianismo de los primeros siglos. En la historia de la cultura occidental, Foucault descubre que los fines asignados a los modos de vida en relación constante con la verdad, se ordenan a partir de dos grandes matrices: primera, en el mundo antiguo, el principio «preocúpate de ti mismo» toma la forma de un dominio de sí sobre sí mismo, como práctica de la verdad; segunda, en el cristianismo de los primeros siglos ese principio toma la forma de un conocimiento de sí sobre sí mismo, de la verdad de sí y de la producción de la verdad de sí. En el mundo greco-romano, la preocupación de sí apunta a la recomposición positiva del êthos, marcado por un gobierno de sí ejercido sobre uno mismo; mientras que en el cristianismo se trata de la producción de una subjetividad marcada por el conocimiento de un individuo sobre sí mismo, y en función de su propio sacrificio.

La naturaleza humana comporta la marca del pecado; la salvación se alcanza rechazando el pecado, renunciando al pecado que es uno mismo. La renuncia de sí, se opera mediante una tecnología hermenéutica, una técnica de interpretación de sí, que devela la verdad de sí. En esta matriz se sitúa el origen 
histórico de las hermenéuticas modernas, aquellas agenciadas por las ciencias humanas, aquellas que apuntan al descubrimiento de un auténtico "yo", o de unos deseos ocultos, o de una naturaleza del hombre. No obstante, a pesar del triunfo de la matriz cristiana, en el Renacimiento - a partir de la relectura de los antiguos- se reabre el acceso a la preocupación de sí como producción positiva y construcción modulada del êthos —desplazando a segundo plano el conocimiento de sí. A partir de su mirada de la filosofía antigua, el Renacimiento reintroduce la idea de la vida como una obra a modelar, arte de vivir — cuestiones que harán tránsito del humanismo, pasando por las llamadas artes liberales, a las bellas artes y a la experiencia de la vida-artista en el siglo xix-. Tal es el caso de Montaigne, cuyos Ensayos ejercen notorias influencias en El sobrino de Rameau de Diderot - obra considerada como la precursora de la apertura de los temas de la estética y de la vidaartista- y en Flaubert, eminentemente ${ }^{57}$. Flaubert instaura el principio "preocúpate de ti mismo» en la composición reflexiva de un modo de vida particular: verdadera vida es la vida por la belleza, en la belleza, para la belleza.

En el pensamiento de Flaubert, la validez de la belleza como principio de sujeción no es simple. El principio de sujeción es posible en cuanto «[...] la Estética es lo Verdadero» (Flaubert, 2007 , p. 894 $)^{58}$, la belleza es la verdad del arte. No se ha de ignorar que ni la verdad ni la belleza son reales, no existen en sí, ni por sí. La verdad no es la verdad de la realidad, ni la belleza está en la eternidad de la naturaleza. Flaubert desrealiza la verdad, desrealiza la belleza. Escéptico, el artista ve que cada época produce a su manera la belleza y también produce la verdad, o sea, la relación o la manera de percibir las cosas - cuestiones tratadas en el capítulo

\footnotetext{
57 En su misiva enviada a L. Colet, fechada el 28 de octubre de 1853, Flaubert (1980) escribe: «Yo releo a Montaigne. ¡Es algo singular como yo estoy pleno de este buen hombre! ¿Es una coincidencia o bien es porque me he llenado de él un año entero a los 18 años, y no leía más que a él? ¡mas me asombro frecuentemente de encontrar el análisis muy profundo de mis menores sentimientos! Nosotros tenemos los mismos gustos, las mismas opiniones, las mismas maneras de vivir, las mismas manías. Hay gente que admiro más, pero no evocaría a nadie con más gusto y con nadie conversaría mejor que con él» (p. 460).

58 Epístola enviada a su sobrina Carolina del 2 de mayo de 1880.
} 
anterior-. Nuestro escéptico artista se sujeta al principio de la belleza por simpathĭa, por complacencia, por sensibilidad.

Yo no tengo necesidad de ser sostenido en mis estudios por la idea de cualquier recompensa, y lo más gracioso es que, ocupándome del arte, no creo más en esto que en cualquier otra cosa, pues el fondo de mi creencia es no tener ninguna (Flaubert, 1973, pp. $397-398)^{59}$.

«Tú me hablas de trabajo, sí, trabaja, ama el arte. De todas las mentiras, esta es la menos mentirosa» (Flaubert, 1973, p. $82)^{60}$. La belleza lo regocija plenamente a Flaubert -fuera de las técnicas hermenéuticas, el sentimiento escapa a la racionalidad, es inatrapable en un orden racional- ${ }^{61}$.

Nadie más que yo tiene el sentimiento de la miseria de la vida. No creo en nada, igualmente ni en mí mismo, lo que es raro. Yo hago arte porque eso me agrada, pero no tengo ninguna fe en lo bello, no más que en el resto (Flaubert, 1973, p. 274) ${ }^{62}$.

El pensamiento no tiene necesidad de un discurso que le haría una ley a obedecer, sino de un modo de ajustamiento de la vida. En suma, el pensamiento de Flaubert hace de la belleza el principio conductor de la vida-artista, la verdad del arte cumple la función de ajustamiento de la vida en el camino de la salvación —al entender el término «salvación» bajo su sentido amplio y etimológico, escapar al peligro, a las venganzas, a las maldiciones, a las desgracias, a los males, alcanzar o conservar un bienestar, entre otros-. "El culto al Arte da el orgullo; uno ahí jamás tiene demasiado. Tal es mi moral» (p. 648) ${ }^{63}$.

59 Epístola enviada a L. Colet del 23 de octubre de 1846.

60 Epístola enviada a L. Colet del 8 de agosto de 1846.

61 «El tedio no tiene causa; querer razonarlo y combatirlo con razones es no comprenderlo»

(Flaubert, 1973, p. 264). En epístola enviada a M. Du Camp en mayo de 1846.

62 Epístola enviada a L. Colet del 6 o 7 de agosto de 1846.

63 En epístola enviada a L. De Maupassant del 23 de febrero de 1873. 


\subsection{Fin estético}

Profusa, difusa, confusa, la idea de felicidad ha recorrido la historia de la cultura occidental. En la felicidad se ha situado el fin de la vida de los hombres y de sus construcciones; ha sido objeto de elaboraciones filosóficas y de usos comunes, de promesas religiosas y promociones comerciales; tratos psicológicos y psicoanalíticos no le han faltado; tampoco ha escapado impunemente a sus detractores que la consideran un fantasma en la vida de los hombres, la quimera de sus sueños e ilusiones. Para Flaubert, la ambición de paraíso es más infernal que el infierno. La felicidad hace correr lágrimas, engendra preocupaciones, causa agitaciones, sin ella uno viviría más tranquilo y cómodo. «No hay que pensar jamás en la felicidad; aquello atrae el diablo, porque es él que la ha inventado para hacer rabiar al género humano» (Flaubert, 1980, p. 331) ${ }^{64}$.

Infernal, la ambición de felicidad se revierte en agitación, en desespero y en tormento sin tregua; puesto que, tal cosa ni se puede alcanzar ni existe, es más, ni siquiera se puede pensar claramente. Dejemos resonar: en la ambición de felicidad -o en sus equivalentes-, el alma es inactiva, está dispuesta para recibir los efectos inducidos por pequeñas contingencias provenientes del exterior; la felicidad es una pasión inactiva del alma. Frente a la imposible y repugnante felicidad, Flaubert busca aproximarse a una tranquilidad asequible, que dependa de él mismo, y cuyo precio puede pagar. «No, yo no creo en la "felicidad posible", sino más bien en la tranquilidad. Por esto es que me aparto de lo que me irrita» (Flaubert, 1998, p. 599) ${ }^{65}$. Sin considerarse un monstruo de egoísmo y fijando la atención en el uso de sí mismo, Flaubert se aleja del bullicio perturbador. Alejarse de los asuntos y personas que irritan es su táctica. Solo, pero tranquilo, Flaubert se expande en sus libros, sus jornadas trascurren amablemente; los malos momentos no faltan, mas se reconforta y aploma considerando 
que nadie lo molesta. Por consiguiente, puede decir: «[...] en fin, me parece que marcho en mi vía natural: luego yo estoy en lo verdadero» (p. 599). Su relación consigo mismo es coherente con su fin moral.

La noción de tranquilidad comporta varios trazos filosóficos del pensamiento de los antiguos y de los modernos, entre los cuales Montaigne se lleva sus palmas. La tranquilidad se define por la coherencia entre êthos, deseos y conducción de conductas; implica evitar malos encuentros y alejamiento de todo aquello que amenaza con deshacer esa coherencia; reclama la fuerza necesaria para gobernarse así mismo; controlar las conductas y refrenar algunas pasiones cuando su satisfacción induce efectos adversos que, bajo ciertas condiciones, pueden subvertir la tranquilidad. Ahí el alma es activa, se tiene y se contiene en sí misma. Hasta las puertas de su muerte, Flaubert reconocerá que después del advenimiento de la vida-artista, después de su juventud, ha sacrificado todo por la tranquilidad de su espíritu. Cuando contaba con veintitrés años, su claridad no era menor. En una epístola dirigida a su gran amigo Alfred, extiende una reflexión casuística: después de sus mocedades amargas, y a las cuales no quisiera volver, su vida rueda regularmente ordenada en todas sus partes. Ese orden conlleva a tener horizontes menos largos y menos variados, pero su profundidad es mayor, se extiende poco y profundiza mucho en lo poco que abarca. Ahora todo está tranquilo, sin embargo, Flaubert repasa los consejos del arquitecto Pradier, hombre de mundo. Le recomienda enamorarse, tener un amor regular como medio para perderle el rastro a su melancolía, que crece con su soledad.

[...] un amor normal, regular, alimentado y sólido, me sacaría demasiado fuera de mí, me turbaría, entraría en la vida activa, en la verdad física, en el sentido común, en fin, y eso es lo que ha sido dañino todas las veces que he querido intentarlo (Flaubert, 1973, p. 241$)^{66}$.

66 En epístola enviada a A. Le Poittevin el 17 de junio de 1845. Veintisiete años después, el 28 de octubre, Flaubert (1998) le escribe a su amiga George Sand: 
La tranquilidad de Flaubert no es plena. Encerrado con sus muros de protección, su soledad algunas veces pesa y engendra fantasmas melancólicos. Lanzarse tras el amor normal es un camino bueno para desmelancolizarse, mas habría que dejar la salvaguarda, descentrarse de sí mismo, abrir el alma pasivamente a las contingencias exteriores. Situarse en el mundo del sentido común y, por ende, recibir su agitación. Flaubert jamás dispuso ni de la sensibilidad ni de las herramientas para deslizarse ligeramente en la abigarrada vida ordinaria de los hombres. Su sensibilidad tan fina como exasperada, su reflexión tan profunda como constante, lo hunden fatalmente en cada cosa. El artista estoico no quiere la soledad melancólica y tampoco quiere ser estremecido por el tumulto ordinario. La tranquilidad no es lo contrario de la soledad y la melancolía, sino de la bestialidad y la agitación de las pasiones. Un año antes de su muerte, cuando cuenta con cincuenta y ocho años, Flaubert reafirma su voluntad de tranquilidad: «[...] renuncio a todo, con tal de que yo tenga la paz, es decir, mi libertad de espíritu» (Flaubert, 2007, p. 582) ${ }^{67}$. De igual manera, lo había hecho treinta y cinco años antes: «[...] yo le he sacrificado mucho a esta libertad; yo le sacrificaré todavía más» (Flaubert, 1973, p. 249) ${ }^{68}$.

La tranquilidad es inseparable de la libertad, entendida no como libre arbitrio, sino como una práctica constante de atención que, a ojo tendido, espía y controla el corazón. Un gobierno de sí sobre sí mismo conduce a tenerse y contenerse en sí mismo.

¡Otra vez en mi antro!

¡Otra vez en mi soledad!

Ahí, a fuerza de encontrarme mal, ahí, yo llego a encontrame bien; de aquí a largo tiempo no pido otra cosa. ¿Qué me falta después de todo? ¿no [sic] es la libertad y el ocio? Yo me he destetado

En cuanto a vivir con una mujer, a casarme como usted me aconseja, es un horizonte que encuentro fantástico. ¿Por qué? Yo no sé nada. Pero es así [...]. El ser femenino nunca ha estado envuelto en mi existencia [...] demasiado para obligar mi persona a otra a perpetuidad (Flaubert, 1998, p. 599).

67 Epístola enviada a su sobrina Carolina fechada el 18 de marzo de 1879.

68 Epístola enviada a E. Chevalier fechada el 13 de agosto de 1845. 
voluntariamente de tantas cosas que me siento rico en el seno de la desnudez más absoluta (Flaubert, 1973, p. 240) ${ }^{69}$.

Sin divertimientos, estando mal por los abrazos de sus dos damas acompañantes, soledad y melancolía, Flaubert se encuentra bien en su tranquilidad, en su libertad, en su ocio. El artista se tiene y se contiene en el uso de sí mismo. La tranquilidad como teleología de la vida-artista no señala un comportamiento puntual, una manera mínima y episódica de actuar con control frente a tal o cual accidente de la vida. La tranquilidad es cierta cualidad del modo de ser, cualidad del êthos, modalidad de una experiencia de sí que hace que los acontecimientos que ocurren alrededor de uno, favorables o desfavorables, produzcan el menor efecto posible sobre uno mismo. Cuando cuenta con cuarenta y ocho años, el oso de Croisset responde a George Sand: «[...] "el enclaustramiento al que yo me he condenado sea un estado de delicias”, ¡no! ¿Mas qué hacer?» (Flaubert, 1998, p. 4) ${ }^{70}$. Y un año después le manifiesta:

[...] yo no pediría mas [sic] que lanzarme a una afección nueva. ¿Mas cómo hacerlo? Puesto que mis viejos amigos están casados, son oficiales, piensan en su pequeño negocio durante todo el año, en la caza durante sus vacaciones, y en el whist después de cenar. No conozco uno solo que sea capaz de pasar conmigo una tarde leyendo un poeta (Flaubert, 1998, p. 190).

El logro del télos asignado a la vida requiere de una práctica de sí mismo que recomponga el êthos y lo equipe de una actitud que module las acciones, y les da su luz singular. Arte de la vida.

\subsection{Tecnología estética}

«Tome la vida, las pasiones y usted misma como un tema de ejercicios intelectuales» (Flaubert, 1980, p. 716) ${ }^{71}$. Flaubert toma su propia vida como materia de ejercicios intelectuales en 69 Epístola enviada a A. Le Poittevin, fechada el 17 de junio de 1845.

70 Epístola enviada a G. Sand el 1 de enero de 1869.

71 Epístola enviada a L. de Chantepie el 18 de mayo de 1857. 
función de hacer de su vida una obra estética. En el siglo XIX, la vida-artista deviene en un uso de sí, en un arte de la vida inscripto bajo el signo de la estética. La idea de vida-artista modula la antigua noción de arte de vivir. En la aurora de la filosofía, un acontecimiento del pensamiento produce la noción de arte de vivir, techné peri bion, a través de la articulación de las nociones techné y bios. La noción de techné (que los latinos tradujeron con la palabra ars) se aplicaba a toda producción realizada por los hombres al poner en juego un saber-hacer, a la posesión de un conocimiento y unas habilidades para producir algo que antes no existía, por ejemplo, el teorema de Pitágoras. «El término techné se aplicaba indistintamente para el saber-hacer propio del zapatero, o del escultor, o del armador de barcos, o del orfebre, o del poeta, etc. [sic]» (Rodríguez Jaramillo, 2018, p. 95). La segunda noción, bios, vida, designaba la manera de vivir, la manera de llevar la vida, la manera de conducir la vida. Arte de vivir ${ }^{72}$ designaba entonces un saber-hacer que tomaba como materia el bios para producir una determinada y reflexiva manera de vivir, un modo de conducirse a sí mismo, un tipo de subjetividad particular. La noción de arte de vivir envuelve un conjunto de procedimientos y prácticas que un individuo efectúa sobre sí mismo, en el uso de sí, para recomponer, transformar, producir un modo de ser, un tipo específico de êthos. Estas prácticas no surgen de la imaginación espontánea de los individuos, se trata de procedimientos y técnicas vehiculadas en diversos tipos de discurso; ellas son propuestas o prescritas a los individuos para fijar su identidad, o sostenerla, o transformarla en función de diversos fines (Foucault, 2014). En la cultura occidental, las prácticas de sí se atan con fines diversos y varias formas de la verdad, se difunden a través de distintos medios. Estas prácticas

72 Al respecto, Foucault (2014) indicaba:

Con seguridad se podría decir que estas artes de vivir (techné peri bion) son exactamente biotécnicas. Pero evidentemente la palabra no podría ser bien empleada, pues el sentido que ahora se la ha dado nos desplaza hacia otra cosa. De tal manera que preferiría, para designar lo que está en cuestión en estas artes de vivir, en lugar del término biotécnica, emplear la expresión: técnica de sí -o tecnología de sí-, puesto que se trata, en todas estas prácticas, de procedimientos reflexivos, elaborados, sistematizados, que se enseñan a los individuos para que puedan, a través de la gestión de su propia vida, controlarla y efectuar una transformación de sí sobre sí, alcanzar un cierto modo de ser (p. 37). 
[...] permiten a los individuos efectuar, solos o con la ayuda de otros, un cierto número de operaciones sobre sus cuerpos y su alma, sus pensamientos, sus conductas, su modo de ser; transformarse a fin de alcanzar un cierto estado de bienestar, de pureza, de sabiduría, de perfección o de inmortalidad (Foucault, 2001f, p. 1604).

Un número significativo de prácticas de sí, inventadas, exploradas, experimentadas por la antigüedad grecolatina, y desatadas del cristianismo, se actualizan en el Renacimiento a través de la relectura de los antiguos y se relanzan a los tiempos modernos. De estas experiencias históricas, Flaubert recibe no pocos elementos que ensambla en un conjunto tecnológico y práctico de higiene intelectual, que constituye una tecnología estético-moral.

Si el campo semántico de la palabra higiene se lleva al dominio del modo de vida, nos aproximamos al sentido de higiene estética, como tecnología de vivir. Higiene designa un conjunto de conocimientos y técnicas que se aplican los individuos para el control de los factores que en un momento dado ejercen o pueden ejercer efectos nocivos para la salud; designa un conjunto de medidas y prácticas de aseo, limpieza y prevención para la conservación de la salud. La higiene estética de Flaubert es un hábito en uso, una disposición de sí mismo marcada por la signatura de la contemplación. Por ejemplo, él dice a una amiga epistolar, sobre quien ejerce una especie de dirección espiritual, «Hay un sentimiento, o mejor un hábito del que me parece usted carecer, a saber, el amor de la contemplación» (Flaubert, 1980, p. $716)^{73}$. A propósito del arte, de los sufrimientos, del tedio o las angustias, o de lo insoportable de la vida, no pocas veces, el artista estoico remite al hábito. Cuando cuenta con veinticinco años, enamorado y despejando malentendidos, le dice a su amante: «[... tú crees que yo quiero mucho el estudio y el arte porque me ocupo mucho en ello. Si me sondeara bien, puede ser que no

73 Epístola enviada a L. de Chantepie del 18 de mayo de 1857. 
descubriera en aquello otra cosa que el hábito» (Flaubert, 1973, p. 429 $)^{74}$. Afiliada a una larga tradición - la cual a partir de Aristóteles y pasando por Tomás de Aquino alcanza los tiempos modernos-, la formación del hábito se efectúa a través de la repetición de actos; y una vez adquirida se instaura en la fuente de los mismos. En la higiene estética, la repetición de los actos es conducida por una serie de reglas. Como el hábito religioso de un monje, todos los días, a la misma hora, aplicarse a la lectura de un clásico, se trata de leer como un trabajo a realizar con seriedad y rigor. "Doctor en melancolía», contando con cuarenta y cinco años, Flaubert prescribe a la amiga:

[...] hay que convocar su voluntad; pero no tiene voluntad quien quiere. No obstante, ¿no podría usted llegar, por una higiene intelectual, a aturdir sus sufrimientos? ¿ $\mathrm{Si}$ usted se diera ocupaciones forzadas, una gran tarea que cumplir? Emprenda largas lecturas, dividiendo la tarea, hora por hora, de una manera monacal (Flaubert, 1991, p. 577) ${ }^{75}$.

No hay voluntad de la voluntad; mas, así como un enfermo se obliga a cumplir un régimen dietético prescrito por su médico, la obligación reglamentada de lecturas se presenta como alternativa en la higiene de sí mismo. La higiene es un régimen de vida que persigue ciertos fines, prescribe ciertas reglas y comanda una serie de acciones bajo determinadas condiciones.

Siguiendo el régimen, cumpliendo con el deber diario, se rompe inicial y episódicamente con los sufrimientos. Una fuerza de continuación empieza a surgir; y continuando se alcanza la formación del hábito.

No son las grandes comidas y las grandes orgías que alimentan, sino un régimen continuo, sostenido. Trabaje cada día pacientemente un número de horas iguales. Toma el pliegue de una vida estudiosa y calmada; ahí tú probarás de entrada un gran encanto y de ahí sacarás la fuerza (Flaubert, 1973, p. 417) ${ }^{76}$.

74 Epístola enviada a L. Colet del 15 de enero de 1847.

75 Epístola enviada a L. de Chantepie del 13 de diciembre de 1866.

76 Epístola enviada a L. Colet del 13 de diciembre de 1846. 
En la tecnología de higiene, el estudio es un pensum, responde a un plan a largo plazo, está enfocado en un tema: «[...] láncese a cuerpo perdido, o mejor a alma perdida, a las letras. Coja un largo trabajo y jure cumplirlo» (Flaubert, 1980, p. 699) ${ }^{77}$. El pensum dispuesto para conducir a la formación de un hábito contemplativo, se despoja de toda servidumbre exterior. Cuando los hombres de disposiciones finas y nobles se entregan al estudio con recogimiento y fervor, encuentran alegrías ideales. La luz de los grandes espíritus envuelve el alma e ilumina la mirada de quienes se asocian a ellos a través del pensamiento; su sensibilidad y su pensamiento se amplían; una simpatía generosa y sin medida envuelve con su manto las penas, los fantasmas y todos los seres. Compenetración de la humanidad. Los trazos individuales de la subjetividad arrogante se disuelven en la contemplación: «Lea profundamente los maestros, no para divertirse, sino para penetrarlos, y poco apoco sentirá disolverse todas las nubes que están en usted. Usted se querrá más, pues contendrá en su espíritu más cosas» (Flaubert, 1980, p. 699). Ampliando el pensamiento, intensificando su fuerza, aumentando la tranquilidad, se acrecienta la estima. En otra carta, Flaubert prescribe:

¡Lea Montaigne, LÉALO lentamente, ¡pausadamente! Él le calmará [...]. Usted lo amará, usted lo verá. Pero no lea, como los niños leen, para usted divertirse, ni como los ambiciosos leen, para usted instruirse. No, lea para vivir. Haga a su alma una atmosfera intelectual que será compuesta por la emanación de todos los grandes espíritus. Estudie a fondo a Shakespeare y Goethe. Lea las traducciones de los autores griegos y romanos, Homero, Petronio, Plauto, Apuleyo, etc. [sic] [...]. Se trata de trabajar, ¿me comprende? (Flaubert, 1980, p. 731) ${ }^{78}$.

Hay que fustigar el pensamiento para liberarlo de su estrechez. El espíritu se procura una atmosfera intelectual luminosa que disipa las sombras. Con efluvios de luz, la vida se hace tranquila. 
Mas, ¿cómo la contemplación disipa las penas? En el uso habitual de la contemplación, el individuo se afecta a sí mismo: en la acción de contemplar deviene en "contemplante». El uso de sí mismo en la contemplación se ejerce mediante el empleo de técnicas de varios tipos.

\subsubsection{Contemplación del mal}

La mirada aguda de Flaubert y su preocupación constante por la existencia lo conducen a hacer de la contemplación de los males una técnica del uso de sí. La epístola dirigida a MarieSophie Leroye De Chantepie el 18 de mayo de 1857, ofrece su generosidad a nuestras cuestiones. Ahí, su autor responde a varios interrogantes que la triste dama le ha formulado. Invitémonos a destacar la respuesta a la pregunta cómo Flaubert logró sanarse de sus alucinaciones nerviosas, que llegaron al límite, a aquel umbral que cuando se pasa ya no se regresa del fondo sin fondo de la demencia. «[...] ¿cómo me he sanado de las alucinaciones nerviosas que yo sufría antes? Por dos medios: $1^{\circ}$ estudiándolas científicamente, es decir tratando de darme cuenta, y, $2^{\circ}$ por la fuerza de la voluntad. Yo he sentido frecuentemente venirme la locura» (Flaubert, 1980, p. 716) ${ }^{79}$.

Un torbellino de ideas y e imágenes en su cerebro le hacían sentir que su conciencia, su yo, se hundía como un barco bajo la tempestad. Angustiarse hasta perder el rastro de sí, entrar en un estado de shock, sería la incapacidad de maniobrar del barco, dejarlo a la topa tolondra de la tempestad y las olas. En el límite extremo, un esfuerzo grave - «fuerza de la voluntad»resiste. En lontananza resuena la voz de Aristóteles: el valiente no es el hombre que no tiene miedo, sino quien no se deja vencer por el miedo. "Gobierno de sí mismo». Hacer del mal una cosa de contemplación es una manera de resistir a la fuerza de aquello que, involuntariamente adviene, mueve y amenaza con precipitarlo a uno en un fondo sin fondo. Aunque sitiada y

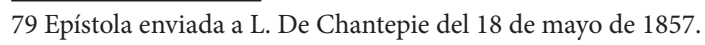


abatida, aún la razón puede algo. Flaubert se aferra a su razón; mas ¿qué puede hacer todavía, qué función puede todavía efectuar en tal estado? «Estudiar científicamente» sus enemigos, las alucinaciones, esto es: ver el torbellino que produce el cerebro, como se ve a un tercero, como se ve un árbol, como se ve una mariposa que pasa tras el cristal de la ventana. Desvincular la mirada de la afección subjetiva, desgarrarse de sí. Se trata de ver. ¡Apatheia! Contemplar, contemplar, contemplar... Mas, ¿cómo, de qué manera la contemplación de ese torbellino delirante sana de las alucinaciones? El sustantivo alucinación proviene de la palabra latina allucinatǐo, -ōnis, que designa el producto de la acción de alucinari. Este término (designa engañarse, vagar con falsas imágenes), el término está formado por la palara griega alyien, vagar, errar, y latina lux, luz. Contemplar la locura: ver las imágenes y el errar de las luces producidas por la mente.

Sin apatheia no hay contemplación. En la apatheia contemplativa se neutraliza, o al menos se disminuye, aquella fuerza de la angustia que emana de la amenaza. En el cuasi abatimiento completo de la consciencia, en ese cuasi, la consciencia aún puede precariamente ser consciente de las alucinaciones y, a la vez, consciencia de la consciencia de las alucinaciones. La consciencia de la consciencia de las imágenes no puede ser otra cosa que una imagen. La reflexividad de la razón introduce la imagen de la consciencia de la consciencia de las alucinaciones en el desfile de imágenes delirantes, como si fuese una alucinación más. La imagen artificiosa, una vez que se ha introducido subrepticiamente en el torbellino de alucinaciones, empieza a hacer su trabajo de resistencia en cuanto va infundiendo consciencia a las imágenes involuntarias. La consciencia de la imagen alucinada es su idea neta en la consciencia, idea neta que implica la operación de desvincular la imagen alucinada de las representaciones asociadas. El pensamiento de Flaubert de la idea neta como desvinculación de la representación equivale al pensamiento de Spinoza de la idea verdadera como idea completa y el de la idea falsa como idea mutilada, que da lugar a las pasiones tristes. 
El «estudio científico» de las alucinaciones no es otra cosa que la práctica de ver las alucinaciones como si fueran líneas, planos, figuras. Estas, al tornarse conscientes, pierden su autonomía de errancia. Dado que cuanto más se neutraliza el errar; el torbellino más pierde su fuerza y a la tempestad le sigue un tiempo en calma. Una crisis nerviosa termina, otro ataque vuelve; a cada crisis su contemplación, y así sucesivamente. La operación de consciencia, mediante la repetición de actos, se hace cada vez más diestra. La familiaridad dada a través de la frecuentación consciente del mal, lo despoja de la sorpresa producida por lo inesperado, tanto en su aparición como en su desenlace; el conocimiento del mal alucinatorio lo despoja del miedo que produce lo misterioso cuando se ignora su fuerza y sus poderes.

En síntesis, el conocimiento del mal alucinatorio deviene en una forma de dominarlo o al menos de controlarlo. Mas ese estudio es imposible sin una voluntad que es doble: voluntad de conocimiento y voluntad de poder de sí. La experiencia de las propias alucinaciones encuentra su condición de posibilidad en la fuerza del uso de sí. Progresivamente, Flaubert se sobrepone a la enfermedad; logra un conocimiento de las alucinaciones y de sí mismo que, acompañado de unas habilidades, lo facultan para contornear la demencia y hacer de ella una experiencia de sí. La descripción de la cura, su afrontamiento, expone los elementos de esa práctica de sí que de cierta manera provee a Flaubert de un equipamiento protector contra las amenazas del imperio de lo fantástico. Flaubert se inmuniza estudiando y contemplando las alucinaciones y la demencia. En y con esa experiencia, Flaubert inventa una técnica de ejercicios intelectuales, que constantemente aplica sobre sí mismo. Otras veces, sin ser víctima de ataques nerviosos, deliberada y artificialmente, se produce los horribles sufrimientos de las alucinaciones a través del recurso a los juegos de su imaginación y memoria: meditación de la locura. En la misma epístola referida, seguidamente al pasaje citado, Flaubert (1980) escribe: 
Otras veces, yo intentaba, mediante la imaginación, darme ficticiamente esos horribles sufrimientos. Yo he jugado con la demencia y lo fantástico como Mirtridates con los venenos. Un gran orgullo me sostenía y yo he vencido el mal a fuerza de abrazarlo cuerpo a cuerpo (p. 716) ${ }^{80}$.

El antiguo rey Mirtridates, sintiéndose amenazado, y siendo experto en venenos, ejerce su techné sobre sí mismo: prepara su veneno, fija la dosis diaria necesaria y la ingiere; se hace inmune a los venenos. Algo análogo hace Flaubert con la demencia y las alucinaciones. Las alucinaciones, la demencia, son objeto de dos tipos diferentes de experiencias de sí, una cuando se trata de enfermedad misma y otra cuando se trata de un ejercicio para alcanzar inmunidad. Este último tipo de práctica es cercana a la experiencia de la alucinación artística. En las alucinaciones provocadas artificialmente, Flaubert ve el cuadro no bien delimitado, aunque preciso, solo se fija en la imagen alucinada mientras que los otros objetos quedan como suspendidos en el aire y sin ninguna relación con ella. La alucinación artística no se extiende sobre un gran espacio, mas se mueve en un cuadro largo, lo que permite la ensoñación. Mas en la enfermedad, primero siente una angustia indeterminada y vaga, un sentimiento de que algo va a llegar; seguidamente, de golpe, como un rayo, irrumpe el delirio.

En su experiencia, Flaubert considera la alucinación como una enfermedad de la memoria, que sufre un relajamiento en sus contenidos. Las imágenes se escapan, se siente que lo hay en la cabeza va a estallar, como fuegos artificiales; no hay tiempo de detenerse a mirar las imágenes internas que desfilan con furia. En otros casos, ha ocurrido que irrumpe una sola imagen que va creciendo hasta cubrir toda realidad objetiva; una chispa que vuela y se vuelve un fuego llameante; todo se confunde. De igual manera le aconteció en su juventud: cuando entraba en una sala de teatro, veía siempre esqueletos en lugar de los espectadores.

80 Epístola enviada a L. de Chantepie del 18 de mayo de 1857. 
Reconocía y sabía con seguridad que veía cosas falsas, mas no por esto dejaba de ver las imágenes irreales. Estas imágenes aparecen desligadas del entorno algunas veces, en otros casos ve por un ojo las imágenes alucinatorias y por el otro los objetos reales, sin poder integrar las dos dimensiones, situación que se torna en un suplicio ${ }^{81}$. El filósofo Taine, interesado en sus investigaciones sobre la inteligencia por el tema de las alucinaciones, formuló a Flaubert algunas preguntas; a las que él respondió:

[...] no asimile la visión interior del artista a aquella del hombre verdaderamente alucinado. Yo conozco perfectamente los dos estados; hay un abismo entre ellos. En la alucinación propiamente dicha, hay siempre terror; usted siente que su personalidad se le escapa; uno cree que se va a morir. En la visión poética, al contrario, hay alegría; es algo que entra en usted. No es menos verdadero que uno no sabe donde $[$ sic $]$ está [...] (Flaubert, 1991, p. 562) ${ }^{82}$.

La tipificación de las alucinaciones en patológicas y artificiales, a partir de sus características específicas, pone en jugo la distinción dos tipos de ejercicios espirituales de Flaubert: la experiencia de su enfermedad de alucinaciones y su experiencia mirtridática de la locura alucinatoria; ambas inscriptas bajo el signo de la contemplación. Estos dos tipos de experiencia son una modulación de la antigua práctica de los males del estoicismo. Hay un tipo de práctica de los males que se efectúa bajo condiciones que permiten ejercitarse directamente con la cosa misma y hay otro tipo que se efectúa solo mediante la meditación. La precisión de la noción antigua de meditación da cuenta de la diferenciación. La noción de meditación, como práctica de sí, no corresponde en absoluto con aquello que hoy designa el término meditar. La palabra meditación en latín, meditatio, era equivalente del sustantivo griego meletê que designaba el ejercicio. Esta palabra estaba muy próxima al de gymnazein que significaba ejercitarse en tal cosa, entrenarse en tal cosa, es decir, una manera de enfrentarse

$81 \mathrm{Al}$ respecto se invita a visitar la epístola a H. Taine, fechada el 1 de diciembre de 1866 (Flaubert, 1991).

82 En epístola enviada a H. Taine el 20 de noviembre de 1866. 
vis a avis con la cosa misma, por ejemplo, entrenarse en lucha era enfrentarse con un adversario para saber si se es capaz de ser más fuerte que él, si se le puede resistir. La meditación es una especie de ejercitación efectuada con el pensamiento y en el pensamiento. La imaginación es convocada para crear un escenario donde el pensamiento se interna no para examinar la cosa frente a sí mismo como si se tratara de una reflexión, sino que se lo asume como algo real, se hace una especie de experiencia de identificación; ahí se trata no tanto de pensar en la cosa misma sino de ejercitarse en la cosa.

La meditación no es entonces un juego del sujeto con su propio pensamiento, no es un juego del sujeto con el objeto o los objetos posibles de su pensamiento... sino el juego efectuado por el pensamiento sobre el sujeto mismo (Foucault, 2001a, pp. 339340).

Por ejemplo, la meditación de la muerte no consistía en pensar sobre la muerte o reflexionarla, sino en sentirse uno mismo muriendo, verse y pensarse muriendo con el fin de romper las representaciones insoportables de la muerte y de alcanzar un equipamiento frente a ella. El estoico adviene inmune al miedo que inducen las representaciones de la muerte. Por una parte, Flaubert medita la locura mirtridáticamente y, por otra, efectúa una práctica directa sobre la enfermedad nerviosa; mas con la experiencia de la segundad, compone la primera. Ni metáfora, ni fantasma ${ }^{83}$, en Flaubert hay un pensamiento y una práctica moral de los males, y cuyo fin es alcanzar la templanza de sí, como un

83 Von Koppenfels, en su artículo La main de Flaubert. Stratégies d’auto-immunisation (2012), enfoca la figura ética del pensamiento desde una perspectiva psicológica, ve que, a partir de una patología, Flaubert compone su estilo literario:

[...] hablaremos de dos cosas: primero de un miembro que choca con insistencia las cartas de Flaubert, seguidamente, de un fantasma psicosomático que influencia toda su producción literaria desde Madame Bovary; de la mano de Flaubert, después de su inmunidad. Buscaremos de entrada mostrar que una está en relación con la otra, que la mano de Flaubert es una representación imaginaria que se encuentra en el centro de sus fantasmas de inmunidad. Seguidamente, intentaremos poner en evidencia que esta mano forma un cruzamiento textual, una especie de ombligo donde lo psíquico y lo somático, lo biográfico y lo literario se encabalgan de modo inextricable» (p. 2). 
modo de protegerse uno mismo de los males que advienen del exterior:

[...] tú me preguntas por qué yo he pasado para haber llegado donde estoy [...]. La mano que tengo quemada, y de la cual la piel está plisada como la de una momia, es mas [sic] insensible al frio y al calor que la otra. Mi alma es igual; ella ha pasado por el fuego. ¡Qué maravilla que ella no se recaliente en el sol! (Flaubert, 1973, pp. $447-448)^{84}$.

A principios de 1844, Flaubert recibió atención médica de su padre, durante uno de sus ataques nerviosos. Su padre intentó regularle el pulso, bañó su mano con agua caliente, mas, en su premura, olvidó que el agua hervía; los dolores y el proceso de cicatrización duraron largo tiempo. Tras la cicatrización, la piel quedó plisada, menos sensible al frío y al calor que la izquierda. El alma de Flaubert ha pasado por agua hirviendo, plisada su piel, ha devenido menos sensible que otras. Que los otros tomen esa experiencia como una debilidad de sí o una enfermedad vergonzosa por haberse aplicado a cosas malsanas poco importa, lo capital radica en el equipamiento alcanzado, protección de sí contra los sufrimientos que advienen en las contingencias de la vida. Si no depende de uno escapar a los sufrimientos, sí está en la mano de uno prepararse para enfrentarlos: práctica estoica. Bajo otra formulación, un año después, Flaubert vuelve al mismo pensamiento:

Los númidas, dice Heródoto, tienen una costumbre extraña. Pequeñitos, se les quema la piel del cráneo con carbones para sean seguidamente menos sensibles a la acción del sol que es devorante en sus países [...]. Sueño que yo he sido criado a la númida. No habría un buen juego en decirle: "usted no siente nada, el sol mismo no lo calienta". ¡Oh! no tengo miedo: por tener cal en el corazón, él no es menos bueno (Flaubert, 1973, p. 279) ${ }^{85}$.

84 Epístola enviada a L. Colet el 20 de marzo de 1847. 85 Epístola enviada a L. Colet el 6 o 7 de agosto de 1846. 
El artista estoico se ha formado a la númida ${ }^{86}$. Un bello juego ha hecho sobre sí mismo: el miedo, el pesar, la tristeza, la euforia sentimental, etc., no queman su corazón. Estos pensamientos señalan hacia una práctica de sí mismo continua desde la infancia. La exposición sostenida y abierta a los males, a los sufrimientos, a la miseria, a su confrontación vis a vis, a su percepción y a su reflexión engendra un hábito, una disposición que permite no estremecerse ni descomponerse frente al a las contingencias inherentes a la condición humana. Sobre sí mismo, Flaubert ha puesto en práctica varias fórmulas estoicas dispuestas para la mejor conducción de la existencia; su higiene moral le ha dado la insensibilidad del corazón, le ha procurado una piel resistente a las inclemencias de la vida, en función de la tranquilidad buscada. En el transcurso ordinario de la vida, no son los grandes acontecimientos que forman la desgracia, o la felicidad, o la tranquilidad, sino un tejido fino e imperceptible de pequeñas circunstancias y detalles. en el día a día, en el rodar cotidiano de la vida, qué hacer con una gran virtud o un gran sacrificio; la paciente construcción del êthos, a través de las pequeñas circunstancias y acontecimientos repetidos, tiene valor moral; uso de sí mismo. Con su tendencia fina a la observación, a la imaginación, a la contemplación, Flaubert se aplica a las prácticas de meditación de los males (ejercicios estoicos que, con frecuencia, denomina ensoñaciones), así como Montaigne hace «[...] uso de esas medicinas que insensibilizan y adormecen la parte» (Montaigne, 1999, pp. 243-244). Cuando cuenta con cuarenta y cuatro años, Flaubert escribe a Colet:

[...] te había dicho que yo era viejo [...]. Si tú supieras todas las fuerzas que me han agobiado, todas las locuras que me han pasado por la cabeza, todo lo que he ensayado y experimentado en el campo de sentimientos y de pasiones [...]. Jamás he visto un niño sin pensar que devendría viejo, ni una cuna sin soñar en una tumba. La contemplación de una mujer desnuda me hace soñar en su esqueleto. Esto hace que los espectáculos alegres se me tornen tristes, y que los espectáculos tristes me afecten poco.

86 Seminómadas, en tierras ardientes, los númidas era el pueblo que mejor soportaba el sol; la preparación de los niños era definitiva para soportar las inclemencias de su ambiente. 
Lloro mucho en el interior para verter lágrimas en el exterior; una lectura me mueve más que un mal real [...] (Flaubert, 1973, p. $275)^{87}$.

Un individuo puede conducirse frente a los sentimientos, emociones, pasiones, sufrimientos, como todos los otros, irreflexivamente - es decir, sin poner en cuestión sus maneras ni sus procedimientos, sin detenerse a examinar el pensamiento impensado que subyace en el bajo fondo de su sensibilidad-; pero también puede hacer de afecciones el objeto de una práctica ética, algo reflexivo y controlado de tal manera que pueda alcanzar unos efectos deseados y fijados desde la partida. Todo ser humano ha pasado por sufrimientos, dolores, tristezas de diferentes clases, generados por diversas situaciones propias o de otros; las muertes, enfermedades, desencuentros, humillaciones, indignidades, pasiones fuertes o pálidas, emociones perturbadoras, etc., han pasan por la vida. Sentir tal cosa, emocionarse, contristarse, alterarse y luego desviar la atención hacia otra cosa, efectivamente no transforma. Un trabajo sostenido, y a largo plazo, modifica el uso de sí mismo. Disponer uno mismo su êthos como tema y materia de un ejercicio intelectual, indica estratégicamente distanciarse de uno mismo para verse y estudiarse uno mismo como se hace con una cosa extraña y exterior. Ver y estudiar se diferencian radicalmente de juzgar, de fijar la lógica de causas, efectos, conclusiones. Ver y estudiar es desvincular, neutralizar la individualización y la subjetivación de las cosas. Desde este punto de vista, Flaubert ve que

[...] hay que habituarse a no ver en la gente que nos rodea más que libros. El hombre de sentido la estudia, la compara y hace de todo eso una síntesis para su uso [...]. La buena y la mala sociedad deben ser estudiadas. La verdad está en todo. Comprendamos cada cosa y no acusemos ninguna. Es el medio de saber mucho y de estar calmado [...] (Flaubert, 1973, p. 96) ${ }^{88}$.

87 Epístola enviada a L. Colet del 6 o 7 de agosto de 1846.

88 En epístola enviada a E. Chavalier el 24 de febrero de 1842. Asimismo, en correspondencia a L. Colet, fechada el 14 de julio de 1847, Flaubert (1973) expresa: «La contemplación de una existencia vuelta miserable por una pasión violenta, de cualquier naturaleza que sea, es siempre una cosa instructiva y de altura moral. Eso degrada con una ironía aullante tantas pasiones banales y manías vulgares hasta el punto en que uno está satisfecho soñando que el instrumento humano puede vibrar hasta allá y subir los tonos agudos» (p. 462). 
La tecnología de la contemplación, ver y estudiar, desmelancoliza. Varios trazos históricos concurren en este tipo de tecnología higiénica, mas toman una manera inusitada. En los tratamientos de la melancolía, en la Edad Media, en el Renacimiento y en los tiempos modernos, es común intervenir los comportamientos del individuo mediante la operación de romper las secuencias armadas entre la soledad, el ocio, las ensoñaciones y el ensimismamiento (consideradas como causas, síntomas inmediatos y, a la vez, efectos). Dar al individuo melancólico numerosas ocupaciones y constante compañía, de tal modo que, al no disponer de tiempo, ni ociosidad, ni soledad; se fuerza a la salida de su ensimismamiento triste y de su laberinto oscuro. En la Edad Media, en el monasterio cristiano, al monje afectado por la acedia se le somete a un régimen, se le obliga a no separarse de los otros, se le da la tarea y el deber de hacer un buen número de oraciones y un buen número de oficios materiales durante el día, y cada día. Así, acompañado, muy ocupado todo el día y los siguientes, el monje melancólico no dispone ni de condiciones, ni de tiempo, ni de fuerza para acariciar sus negras representaciones. En los tiempos modernos, la relación entre el hombre estudioso y el sujeto melancólico es una referencia común que se extiende desde el Renacimiento hasta el siglo de Flaubert. La mayoría de los hombres de letras y los artistas, en general, portan la llamada «enfermedad del siglo». En esos tiempos, es común encontrar en la higiene las recomendaciones de dar trabajos materiales, buscar compañía de otras personas y diversiones de diferente índole, viajes, paseos, trabajos, etc. En sus retomas, Flaubert hace algunas modificaciones significativas. Con frecuencia se procuró alejar el individuo melancólico de los libros, pues ellos favorecen la soledad, el ensimismamiento, las ensoñaciones; Flaubert introduce el estudio, la lectura, la meditación, mas no tuerce un punto que parece ineludible: sacar al individuo del fondo sin fondo de su tedio, de su ensimismamiento, es decir, de su manía de individualizar y subjetivar las cosas. El recurso del estudio va en esa dirección, pero comporta un pensamiento tan grave como inusitado: el estudio sustrae a las almas nobles del fango ordinario 
del mundo común de los hombres, los desprende de sí mismos y los amarra a la belleza. Y otro tanto va con la práctica de la escritura la cual, de cierta manera, redobla la práctica de contemplación.

\subsubsection{Escritura de contemplación}

Más importante que la importante obra de arte de escritura, la escritura de Flaubert se dispone en una tecnología estético-moral del uso de sí mismo: «yo soy un hombre pluma [...]» (Flaubert, 1991, p. 34). La escritura responde punto por punto al régimen higiénico-espiritual, y está amarrada apretadamente con el estudio y la contemplación de la belleza. Conocido es que Flaubert hace amplios trabajos de investigación, numerosas lecturas ${ }^{89}$, grandes estudios particulares para la composición de sus obras, la creación de sus personajes, el diseño de sus escenarios, etc. Si bien este trabajo arduo corresponde a exigencias de su estilo y técnicas artísticas, no es menos cierto que desbordando esa dimensión constituye una de las maneras de la vida contemplativa. La escritura no es un medio para alcanzar otra cosa, su fin está en ella misma; puesto que en sí misma es un modo de la contemplación. Por ejemplo, algunas veces, Flaubert escribe trozos de sus libros con el pleno conocimiento de su inutilidad en el conjunto de la obra y de su supresión seguidamente a su composición: contemplación sostenible y sostenida. «Un libro ha sido siempre para mí una manera especial de vivir, un medio de meterme en cierto medio [...]. Mi existencia es plana como mi mesa de trabajo e inmóvil como ella» (Flaubert, 1991, p. 34) ${ }^{90}$.

Leer para vivir; escribir para vivir: uso de sí mismo. En la longitud de tiempo del ejercicio de escritura, la existencia es plana e inmóvil como la mesa de trabajo: desprendimiento, desindividualización, des-subjetivación de la vida activa que da lugar a la vida contemplativa. Cuando Flaubert escribe vive mundos.

89 A partir de ahí, una respuesta puede encontrarse para quienes se sorprenden por el número de lecturas hechas por Flaubert para sus composiciones, y para quienes ven en ello una exageración inútil y hasta una actitud malsana para la escritura de las obras.

90 Epístola enviada a J. Sandeau, el 7 de agosto de 1859. 
Es el espectador contemplativo de ambientes, situaciones, de la vida de los personajes de su obra. Ver los personajes solo en las visibilidades de su aparecer. (El término espectador proviene de la palabra latina spectator, spectatoris, quien tiene el hábito, la disposición de mirar y observar, quien es observador, contemplador). Flaubert, con su rigor de investigador e historiador, con su trabajo de documentación y estudios, sitúa con precisión los hechos históricos, sus tiempos y espacios, el decoro de sus ambientes, como monumentos, como cosas hechas, y no como cosas a representar, interpretar.

La ficción literaria es fiel a los monumentos, las tramas, las situaciones, lasperipecias delospersonajes; sussituacionesemergen como aquello que pudo haber sido o puede ser. Ahí la ficción no juega el rol de imaginaciones contrapuestas a la realidad, no son lo otro de la realidad, la ficción es un pensamiento, un sistema de racionalidad que instaura un orden de cosas susceptibles de haber irrumpido o de irrumpir como cosas hechas por los hombres. Los discursos de Proudhon o Napoleón III no dicen la realidad ni del Estado, ni de la sociedad, ni de los modos de producción; puesto que, por una parte, ninguno de estos existe ontológicamente. Y por otra, lo real es irracional; ellos hacen ficciones, dicen cosas susceptibles de haber sido hechas o que pueden llegar a ser hechas por los hombres. Lo real de esos discursos radica o bien en cuanto son una cosa hecha, una práctica discursiva. El orden del pensamiento no puede ser otra cosa que ficción. En consecuencia, ficciona el político, el gobernante, el agitador social, el psiquiatra; ficciona Flaubert. Los mundos que vive este último, a través de la ficción y la contemplación, no son imaginaciones de cucaña. Lo real de su ficción está en el uso de sí, en su experiencia de contemplación. Los mundos vividos por el novelista son un tipo de pensamiento y de sensibilidad particulares.

Yo estoy físicamente fatigado. He tenido dolores en los músculos. El envenenamiento de la Bovary me había hecho vomitar en mi vaso de noche. El asalto de Cartago me procura curvaturas en los 
brazos. $-\mathrm{Y}$, no obstante, es mediante eso que el oficio ofrece lo más agradable-(Flaubert, 1991, p. 176 $)^{91}$.

En la escritura de Salammbô sufre dolores en el dorso por mover catapultas y cargar balas. De su última obra, dice: «iBouvard et Pecuchet me abarrotan hasta tal punto que yo he devenido ellos! Su imbecilidad es la mía y yo me muero» (Flaubert, 1998, p. 920). En una carta al filósofo Taine, escribe: «[...] mis personajes imaginarios me afectan, me persiguen, o mejor soy yo que estoy en ellos» (Flaubert, 1991, p. 562). Sin distracción alguna, Flaubert se compenetra y se contiene en la idea, entonces el pensamiento se siente en su uso propio: «[...] yo escribo para mí solo, como fumo y como duermo. Es una función casi animal, en tanto que es una función personal e íntima. Yo no tengo nada en vista cuando hago algo más que la realización de la idea [...]» (Flaubert 1973, p. 467). Dos años antes, había escrito a uno de sus grandes amigos, algo similar: «[...] en fin, yo creo haber comprendido una cosa, una gran cosa, es que el bienestar para la gente de nuestra raza está en la idea, y no en otra parte» (Flaubert, 1973, p. 252) ${ }^{92}$.

Al concluir este segmento, se puede expresar que las prácticas de sí envueltas en la tecnología higiénica intelectual conducen, reflexiva y regladamente, a la creación de un hábito de contemplación, que una vez adquirido, se instaura en la fuente de los actos y las conductas de Flaubert. La contemplación deviene en praeceptum, techné, habitus y praxis. Como precepto, es idearegla que ordena y conduce la moral estética; como técnica, es el saber y habilidad que conduce a la producción de un tipo de vida otra; como disposición, es la actitud permanente de un modo de pensar, sentir y decir; como práctica, es la producción del êthos. En la vida-artista se bordea la ataraxia (aquello que el estoicismo ha inventado para la moral). Pero, uno no escapa a la condición humana. Abajo de la montaña sagrada está la llanura prosaica. Si bien Flaubert logró dejar a un lado el lamento por el fango de la vida común de los hombres de su siglo y logró protegerse de la bêtise 
de su siglo, jamás pudo ser indiferente a ella. A la apatheia solo se aproximó. Y cómo disponer de una actitud de indiferencia frente a la bêtise, si ella está en el corazón de su experiencia históricocrítica de la vida o, si se prefiere, de la experiencia histórico-crítica de la bêtise. Para Flaubert, la verdadera moralidad es la belleza; luego, la verdadera inmoralidad es la bêtise - tema que conduce al capítulo siguiente-. 



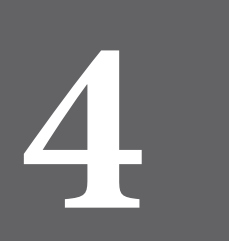

CAPÍTULO

CUATRO 



\section{Desmoralizador}

«Si acaso llego a tomar una parte activa en el mundo será como pensador y como desmoralizador. Yo no haré más que decir la verdad, mas ella será horrible, cruel, desnuda [...]» (Flaubert, 1973 , p. 37 $)^{93}$. Diecisiete años tiene Flaubert en 1839, cuando aburrido de sí mismo y aburridor para los otros, melancólico y airado, escribe ese sueño. La imagen prospectiva insinúa la práctica de la verdad que él efectuará en su obra. Ejercicio definido por la naturaleza del acto de verdad: ética de la verdad. La práctica de veridicción implica varias condiciones: diciendo la verdad, Flaubert se ata a ella; la verdad se dice clara y directamente — desnuda-; con la verdad - horrible, cruel - apunta a inducir unos efectos contra-culturales, que requieren la fuerza del «orgullo» del arte: el coraje de la verdad.

93 Epístola enviada a E. Chevalier el 24 de febrero de 1839. 
El arte moderno es el cinismo en la cultura vuelto contra ella misma [...] es en el arte sobre todo que se concentran, en el mundo moderno, en nuestro mundo, las formas más intensas de un decir-verdadero que tiene el coraje de tomar el riesgo de herir (Foucault, 2009, p. 174).

Diciendo la verdad, Flaubert asume un papel de desmoralizador. La obra de arte de escritura deviene en una práctica de veridicción de Flaubert. Nos interrogamos: ¿de qué manera los libros de Flaubert son una práctica de la verdad con una función anti-cultural? ¿Bajo qué condiciones Flaubert puede practicar un tipo de veridicción desmoralizante, en la que está comprometido su êthos, sin caer en fricciones con su principio de la impersonalidad del arte? El objetivo de este capítulo es ensayar la construcción de respuestas posibles a estos interrogantes.

\section{1. «No haré más que decir la verdad»}

En Salammbô, con un escenario situado en Cartago, tres siglos antes de la era cristiana, Flaubert reconoce su veridicción:

[...] yo he escrito horrores y aquello me complace [...]. Mas ¿qué será esto? ¿qué será esto?... No se desprende de este libro más que un inmenso desdén por la humanidad (hay que quererla muy poco para haberlo escrito). El lector ahí será vagamente ofendido, yo te lo predigo, y él estará resentido conmigo (Flaubert, 1991, p. $172)^{94}$.

Unos días antes, en otra epístola, anticipa a su amigo Ernest los efectos que inducirá:

Salammbô $1^{\circ}$ molestará a los burgueses, es decir a todo el mundo; $2^{\circ}$ alterará los nervios y el corazón de las personas sensibles; $3^{\circ}$ irritará a los arqueólogos; $4^{\circ}$ parecerá ininteligible a las damas; $5^{\circ}$ me hará pasar por pederasta y antropófago. ¡Esperémoslo!” (Flaubert, 1991, p. 170) ${ }^{95}$. 
En esa obra se ha construido un bloque compacto de pasiones puras y perceptos, ninguna grieta deja insinuar trazo alguno de los torbellinos de «excitación» propios del tipo de subjetivación del siglo XIX. Ahí, todas las diferencias específicas de la bêtise moderna -sus pasiones pálidas, su subjetividad arrogante, su excitación sin fondo, sus «buenas costumbres», sus discursos de verdad, sus juicios concluyentes, entre otros-, dado que no solamente no tienen lugar, sino que brutalmente son deslegitimados al hacer de las fuerzas graves el motor de las acciones humanas. Flaubert lo hace visible con su veridicción. Diciendo la verdad, Flaubert se reconoce a sí mismo y es reconocido por los otros como desmoralizador. De Madame Bovary, apenas publicada en un periódico, Flaubert escribe, el 12 de diciembre de 1856:

La Bovary marcha más allá de mis esperanzas. Las mujeres solamente me miran como "un horror de hombre". Se encuentra que yo soy muy verdadero. He aquí el fondo de la indignación. Yo encuentro que soy muy moral y que merezco el premio Montyon, porque de esta novela se deriva una enseñanza clara, y si "la madre no puede permitirle la lectura a su hija", bien creo que los maridos no harán mal al permitirle la lectura a su esposa (Flaubert, 1980, p. 652).

Y no se equivocaba. Un mes después, el 29 de enero de 1857, Flaubert está frente al Tribunal Correccional de París. Le habían abierto un proceso por los delitos de ultraje a la moral pública, la religión y las buenas costumbres, según los artículos $1 .^{\circ}$ y $8 .^{\circ}$ de la Ley del 17 de mayo de 1819, y de los artículos 59 y 60 del Código Penal. En representación del Ministerio Público, el agudo abogado imperial y gran conocedor de la obra de Flaubert, estratégicamente caracteriza como pintura realista y descriptiva el género de arte cultivado por este. Destaca cómo el novelista practica con excelencia ese género al hacer uso de todos sus recursos, pero sin precauciones ni freno. También señala que el tema preferido de Flaubert es pintar las tentaciones, las pasiones, y que lo hace de tal manera que no es posible a nadie dar mayor vivacidad, color y energía a las imágenes y expresiones. Seguidamente pasa a la acusación y dice: 
Yo sostengo que la novela de Madame Bovary, considerada desde el punto de vista filosófico no es en absoluto moral [...] ¡el libro es inmoral! [...]. Esa moral estigmatiza la literatura [...] no porque ella pinte las pasiones: el odio, la venganza, el amor; el mundo no vive más arriba de ellas, y el arte ha de pintarlas; pero cuando ellas se pintan sin freno, sin medida... El arte sin regla no es ya el arte; es como una mujer que se quitara toda la ropa. Imponer al arte la única regla de la decencia pública no es someterlo, sino honrarlo. No se crece más que con una regla. He aquí, señores, los principios que profesamos, he aquí una doctrina que defendemos con consciencia (Pinard, 1857, p. 1).

La acusación toca varios puntos-calve: primero, el estigma moral o la inmoralidad del libro no consiste en pintar las pasiones, puesto que todo el mundo vive bajo su imperio. El abogado imperial en ningún momento acusa a Flaubert de falso, ni de escribir mentiras o imágenes irreales; por el contrario, él ve que el artista pinta muy bien lo real. Segundo, la inmoralidad del libro consiste en pintar las pasiones crudamente, «como una mujer que se quitara toda la ropa»; dicho abogado y el Ministerio Público son el nombre del régimen moral del siglo xIx. Su cuestión se sitúa del lado del poder de la verdad, de los efectos que induce: ponerle regla y medida al arte no es otra cosa que controlar políticamente los efectos que la verdad puede inducir en la sociedad. Y Flaubert es consciente de ello, es más, los fines que se ha propuesto alcanzar con su veridicción son los mimos: hacer que la verdad induzca efectos desmoralizantes. Flaubert devuelve a su sociedad su propia verdad; mas su veridicción ejerce una función anti-cultural al oponer al consenso de la cultura el coraje de la verdad desnuda, horrible, cruel. Sus libros son el cinismo de la cultura vuelto contra ella misma. La obra establece una relación con lo real que no es del orden de la mímesis, ni de la representación, ni del ornamento, sino de la puesta al desnudo, del desenmascaramiento de aquello que no tiene espacio ni legitimidad en la cultura para manifestarse (cf. Foucault, 2009, p. 173). Horrible, cruel, desnuda, la verdad es el espejo astillado que aboca a la sociedad a verse en él, pero sin poder reconocerse. ¿Cuál es el estatuto y el protocolo de la veridicción moral de Flaubert? 
El discurso delasobras de Flaubert es susceptible de examinarse bajo una dimensión moral y política, mas no bajo la pendiente de lo que comúnmente se llama literatura comprometida. Se trata de desplazar la interrogación de estos dos primeros factores sobre el contenido programático del decir, hacia la práctica del decir mismo, hacia el acto de veridicción como cosa hecha. Desde este punto de vista, la veridicción de Flaubert pretende inducir una serie de efectos en el gobierno de las conductas. Su grito resuena:

Yo execro todo lo que es obligatorio, toda ley, todo gobierno, toda regla. ¿Quién eres tú entonces, oh sociedad para forzarme a lo que sea? ¿Qué Dios te ha hecho mi maestro? Observe que usted cae en las viejas injusticias del pasado. Ya no será más un déspota que prima sobre el individuo, sino el pueblo, la salud pública, la eterna razón de Estado, la palabra de todos los pueblos, la máxima de Robespierre. Yo prefiero el desierto, retorno donde los beduinos que son libres (Flaubert, 1980, p. 719) ${ }^{96}$.

¡Obligación, ley, gobierno, razón de Estado, sociedad, pueblo! Frente a las relaciones de poder del siglo xIx, Flaubert ejerce su impaciente libertad. La fuerza política de esta, el artista la ejerce contra el poder de la bêtise moderna. Su acto de arte resiste al poder que, bajo la legitimación antropológica (de la razón del más fuerte, o de sus discursos de verdad) y la promoción de una subjetividad «excitante», mata la vida mediante la operación de sustraer las cosas de su movimiento histórico. Política de nosotros mismos, de nuestro modo de ser como blanco estratégico del gobierno de los hombres en su vida cotidiana. Por ejemplo, a propósito de la muerte de su gran amigo Gautier, Flaubert no duda de que: «Théo ha muerto envenenado por la carroñería moderna. La gente exclusivamente artista, como él, no tienen nada qué hacer en una sociedad donde la plebe domina» (Flaubert, 1998, p. 600) ${ }^{97}$; «[...] él ha muerto, yo estoy seguro de una sofocación muy larga por la bêtise moderna» (Flaubert, 1998, p. 593) ${ }^{98}$. La infección moderna, la política de la subjetividad, ahoga al artista:

96 Epístola enviada a L. de Chantepie el 18 de mayo de 1857.

97 Epístola enviada a I. Tourgueneff el 30 de octubre de 1872.

98 Epístola enviada a su sobrina Carolina el 25 de octubre de 1872. 
[...] èl [sic] ha tenido dos odios, el odio a los comerciantes en su juventud, ese le ha dado el talento. El odio al delincuente, en su edad madura, este último lo ha matado [...]. Ha muerto de cólera regresiva y por la rabia de no poder decir lo que pensaba (Flaubert, 1998, p. 598) $)^{99}$.

En la segunda mitad de 1872, cuando se lanza a la composición de Bouvard et Pecuchet, escribe sobre su moral:

[...] la mía por el momento está bastante bien porque yo medito una cosa en la que exhalaré mi cólera. Sí, yo me desembarazaré al fin de lo que me ahoga. Vomitaré sobre mis contemporáneos el disgusto que $m i[s i c]$ inspiran, aunque tenga que romperme el pecho; esto será largo y violento (Flaubert, 1998, pp. 583-584) ${ }^{100}$.

Aún más, del fondo de su actitud crítica suben fuerzas que mueven y sostienen la vida misma del novelista: «[...] ¡lo que me sostiene es la indignación que me procura la bêtise del burgués!» (Flaubert, 2007, p. 282) ${ }^{101}$. La ética de la verdad alcanza su dimensión política. En 1855, antes de la publicación de Madame Bovary, frente a una moda intelectual que rechaza la forma y proclama la utilidad política de la literatura como su razón de ser, frente a una sociedad que ve la grandeza del artista a través de las pasiones de moda y la simpatía de los envidiosos, Flaubert escribe a su amigo Bouilhet:

[...] yo siento contra la bêtise de mi época olas de odio que me ahogan. Se me sube la mierda a la boca como en las hernias estranguladas. Pero yo quiero guardarla, fijarla, endurecerla; quiero hacer con ella una pasta con la que embadurnaré el siglo XIX, como se cubre de estiércol de vaca las pagodas indias [...] (Flaubert, 1980, p. 600) ${ }^{102}$.

Enmierdar la sociedad del siglo XIX es la consigna moral y política de la veridicción de Flaubert. Su decir verdadero no

99 Epístola enviada a G. Sand el 28 de octubre de 1872.

100 Epístola enviada a R. des Genettes el 5 de octubre de 1872.

101 Epístola a M. Sand el 29 de agosto de 1877.

102 Epístola del 30 de septiembre de 1855. 
corresponde al papel de un predicador, ni de un sabio, ni de un científico; su veridicción no se asemeja a la de un profesor el cual trataría de sacar de la ignorancia a sus discípulos mediante una techné reconocida, aceptada y de necesaria posesión para integrarse mejor en una sociedad ${ }^{103}$. El papel de él es de pensador y desmoralizador, o sea, el del crítico que habla en nombre de sí mismo y dice la verdad de los modos de vivir de su siglo. No juega el papel de promotor y animador de la integración, que el consenso de la cultura reclama, sino el de agente de desintegración o de subversión.

Yo tendría necesidad (si tuviera menos orgullo) para soportar todas las críticas que me han eructado. La sinfonía es completa. Ninguno de todos los periódicos falta a su misión [...]. Y siento, en el fondo, el odio contra mi persona. ¿Por qué? Y ¿a quién he hecho mal? Todo puede explicarse en una palabra: yo molesto; y yo molesto aún menos por mi pluma que por mi carácter [...] (Flaubert, 1998, pp. 792-793) ${ }^{104}$.

En la excavación de la verdad de la bêtise y en su exposición, Flaubert hace rodar su tonel. Conviene hacer notar que un acto o una práctica de "desmoralización» no se sitúa en un lugar de exterioridad respecto a la moral que confronta, si se entiende por moral, como lo señala Foucault (1984), un conjunto de valores y reglas de acción que son propuestas a los individuos por medio de aparatos prescriptivos y también los comportamientos reales delos individuos en relación con las reglas y valores propuestos, es decir, la manera según la cual se someten más o menos, completamente, a un principio de conducta, a la manera de obedecer o de resistir, a la manera de respetar o descuidar un conjunto de valores.

103 En la historia de la cultura occidental se puede identificar cuatro prototipos de quien dice la verdad: el papel de profeta, de sabio, de técnico - quien posee un saber-hacer-, y de crítico - parresiasta-. Si bien estos prototipos, en su emergencia, aparecen definidos y diferenciados; a lo largo de la historia se han combinado unos con otros de diferentes maneras. Algunas veces un mismo individuo ha ejercido la función de varios tipos de sujeto de veridicción en diferentes dominios de cosas, y otras veces dando mayor relevancia a un papel sobre los otros (cf. Foucault, 2016, pp. 104-105).

104 Epístola enviada a R. des Genettes el 1 de mayo de 1874. 
La manifestación de la verdad desnuda, como práctica desmoralizadora y acto de veridicción, está inscrita en la dimensión de la moral: «¡Tú percibes que yo devengo moralista! [...] ¡Ah! lo que falta a la sociedad moderna no es un Cristo, ni un Washington, ni un Sócrates, ni un Voltaire mismo; es un Aristófanes, pero él sería lapidado por el público [...]» (Flaubert, 1980, pp. 208209) ${ }^{105}$. Sin duda, ese Aristófanes es él mismo. Al sustituir la figura de Diógenes por la de Aristófanes, el artista declina el cinismo en lo cómico, en un tipo de cómico que, al rebasar las fronteras de la burla retórica o literaria, porta todo el peso de la crítica moral del cinismo antiguo. ¡El cínico es un crítico! Hijo de Zeus («nacido de su cabeza») y descendiente de Heracles («el trabajador sin descanso"), el cínico es el héroe de la vida filosófica antigua, su alethurgia, su manifestación visible de la verdad envuelve una crítica radical al mundo de los hombres.

Trabajando en sí mismo hasta sus extremos límites la verdad y los valores enunciados por los elevados discursos morales, los retorna escandalosamente a la sociedad. Su alethurgia crítica porta la insolencia por blasón: «el cuerpo mismo de la verdad es vuelto visible, y risible, en un cierto estilo de vida. La vida como presencia inmediata, aclaradora y salvaje de la verdad, es lo que está manifestado en el cinismo [...]» (Foucault, 2009, pp. 160161). «Irónico, provocador, desafiante, el cínico muestra a los otros, en y con su propia vida, cómo se contradicen, se engañan, se mienten, sobre sus propios valores y su propia verdad» (Rodríguez Jaramillo, 2018, p. 156). Mas como actitud moral que como doctrina, como experiencia histórico-crítica de la vida, el cinismo es vehiculado en la alethurgia estética de Flaubert, en su veridicción de la bêtise moderna. «Ser imbécil, egoísta y tener buena salud, he ahí las tres condiciones requeridas para ser feliz. Pero si la primera le falta a usted, todo está perdido» (Flaubert, 1973 , p. 298) ${ }^{106}$. Tal vez, también podría decirse que al artista que le falte esa primera cualidad, será fatalmente un crítico. Pensando 
la bêtise, Flaubert opera una crítica grave, pone ante los ojos de sus lectores las diferentes formas de su bajeza, sus ilusiones, sus vicios, sus grotescos. En su veridicción, desmixtifica y escava la bêtise hasta reducirla a lo elemental y mostrar su verdad. Su crítica traduce una lucha intempestiva contra los bajos fondos de las conductas de su siglo. Su actitud crítica

[...] es el movimiento por el cual el sujeto se atribuye el derecho de interrogar la verdad acerca de sus efectos de poder, y al poder acerca de sus discursos de verdad, la crítica será el arte de la inservidumbre voluntaria, el de la indocilidad reflexiva [...] (Foucault, 2015 p. 39).

La actitud crítica de Flaubert es la fuente de su veridicción. ¿En qué condiciones, de qué modo Flaubert puede practicar un tipo de veridicción desmoralizante, en la que está comprometido su êthos, sin caer en fricciones con su principio de impersonalidad del arte?

\subsection{Anatomía de la bêtise}

El decir verdadero de Flaubert es un tipo de alethurgia estética, una manifestación de la verdad mediante un acto en el que su subjetividad se amarra a lo enunciado. Su carácter estético le marca la manera absoluta a través de la cual se hace visible aquello que no ha estado oculto, sino ante los ojos de todos; pero que, por su frecuentación y familiaridad, no se ve. Mas el arte es impersonal. Al respecto, se debe considerar que, primero, el arte tiene raíz en el êthos. Los temas de sus libros han perseguido a Flaubert mucho antes de haberse abierto a ellos; la insoportable bêtise y el amor a la belleza lo lanzan sin el juego de un libre arbitrio a sus composiciones. Cuando aplastado por el peso de la masa de sus temas, sufriendo fatiga tras fatiga, se pregunta por qué no deja todo eso y mejor escribe sobre otra cosa, se responde «[...] no soy libre de escoger, lo que es verdadero. Mi empeño en este trabajo entra completamente en lo que el doctor Trélat 
llama "locura lúcida"» (Flaubert, 2007, p. 402). En su obsesión, el artista extiende su mirada a muy pocas cosas y se hunde mucho en lo poco que abarca. A George Sand, Flaubert manifiesta su imposibilidad de inclinarse a su estilo, que, partiendo de lo ideal, de la teoría, luego desciende a la tierra con gran indulgencia con la vida, con serenidad, con grandeza de carácter:

[...] si yo quisiera tomar su manera de ver el conjunto del mundo, me volvería risible, he aquí todo. Pues por más que me predique, yo no puedo tener otro temperamento que el mío, ni otra estética que aquella que es consecuencia de él (Flaubert, 2007, p. 11) ${ }^{107}$.

Su estética es consecuencia de su temperamento: «[...] ¡uno se hace un sistema a partir de su temperamento y uno no escoge su temperamento, etc. [sic]!» (Flaubert, 1991, p. 146) ${ }^{108}$. Con raíz en su modo de ser, el artista compone su régimen estético, su sistema de racionalidad; todo ello a través de estudios, ensayos y experiencias. Segundo, el sistema estético. El decir de Flaubert es franco «Tú hablas de mi franqueza cínica; sea consecuente: crea en ello, en esa franqueza» (Flaubert, 1973, p. 322) ${ }^{109}$; mas sin su odio militante contra la bêtise, sus obras serían imposibles. Pero, si sus afecciones o aflicciones, su «corazón», su biografía, su juicio, ocuparan un lugar eminente en la obra, esta se hipotecaría a su subjetividad, y el decir franco y verdadero del libro se obstruiría.

Los libros de Flaubert son verdaderos y francos como su autor. El pensamiento compone su protocolo y su tecnología de la verdad, fija la coherencia entre sus reglas, técnicas y procedimientos. Así, a) el libro es verdadero en cuanto el plan, la composición, el tema, los escenarios, los personajes, las situaciones, las acciones, las cronologías, entre otros elementos. Pasan por un estudio riguroso, por un método y por un modo de observación a la manera de un estudio científico. Por ejemplo, las investigaciones sobre de las pasiones sentimentales o el envenenamiento en Madame Bovary,

107 Epístola enviada a G. Sand el 6 de febrero de 1876.

108 Epístola enviada a E. Feydeau el 21-25 de febrero de 1861.

109 Epístola enviada a L. Colet el 31 de agosto de 1846. 
las pesquisas históricas sobre "pasiones inactivas» en La educación sentimental o en Salammbô, la revisión de mil quinientos libros y tratados sobre las «ideas recibidas» en Bouvard y Pecuché, la lectura de varios centenares de tomos sobre la historia de las religiones antiguas para la composición de los cuadros delirantes en La tentación de san Antonio. "La imparcialidad de la pintura alcanzaría entonces la majestad de la Ley - ¿y la precisión de la ciencia?-» (Flaubert, 1991, p. 786 ${ }^{110}$. Así, el libro dice de una investigación traducida en el lenguaje del arte y convertida en crítica eminente, "[...] es decir el examen de las cosas» (Flaubert, 1998, p. 376) ${ }^{111}$. Examinar las cosas implica esquivar y rechazar la tentación pasional de juzgar lo trivial, o lo monstruoso, o lo intolerable. Ningún personaje del artista es un héroe ni tampoco un monstruo. El pensamiento del arte ha enseñado a Flaubert a despojar las cosas y los individuos de su sentido peyorativo o apologético; hay que desubjetivar y desindividualizar el trabajo. Sus libros son francos en cuanto no son del orden de la mímesis, no representan lo real de los comportamientos, ni son del orden del divertimiento; ellos son visibilidades, manifestaciones de la verdad de la bêtise y de la bêtise en su verdad. b) Cada libro es verdadero como acto de veridicción de su autor. Aquí no se trata en absoluto de si el contenido del libro corresponde o no corresponde, si representa o no representa, si dice o no dice la verdad de la realidad. Aunque Flaubert esté equivocado, su pensamiento está adherido y comprometido con la manifestación de la verdad que hace visible el libro: «[...] yo me limito entonces a exponer las cosas tales como ellas me aparecen, a expresar lo que me parece verdadero. No importa las consecuencias [...]» (Flaubert, 1991, p. 786). No se trata en absoluto de un uso relativista de las percepciones, ni de las reflexiones ni de las descripciones, no se trata de expresar una mirada de acuerdo con el cristal con que se mira; la poética de Flaubert proscribe todo aquello. ¿Cómo el libro es un acto de veridicción crítico sin comportar el juicio o la opinión de su autor? Flaubert reflexiona el problema: 
¿Qué forma hay que tomar para expresar a veces su opinión sobre las cosas de este mundo, sin riesgo de pasar, más tarde, por imbécil? Esto es un rudo problema. Me parece que lo mejor es pintar, buenamente, esas cosas que le exasperan. Disecar es una venganza (Flaubert, 1991, p. 711) $)^{112}$.

El decir verdadero opera con una técnica: disecar, pintar, es decir: examinar, estudiar, observar, para luego describir. La técnica de disecar, ante todo, requiere efectivamente de las competencias y de la asepsia subjetiva del anatomista: «La primera cualidad para ver es poseer buenos ojos. Pues, si ellos están turbados por las pasiones, es decir por un interés personal, las cosas se le escapan» (Flaubert, 2007, p. 139) ${ }^{113}$. La venganza de artista consiste en pintar las cosas, hacerlas ver reduciéndolas a lo elemental de su aparecer, desvinculándolas del juicio, de las categorías que las individualizan y las someten a un orden de las causas - como si lo real fuera racional-. La venganza de artista no es descubrir lo oculto y mostrarlo, sino pintar las cosas tal como ellas son, como aparecen en sus visibilidades ante los ojos de todos. Para pintar hay que estudiar, examinar meticulosamente cada cosa, cada uno de sus detalles y los detalles del detalle hasta verle los poros a las cosas. "Yo sé ver y ver como [sic] ven los miopes, hasta los poros de las cosas, porque ellos pegan su nariz a las cosas» (Flaubert, 1980, p. 30) ${ }^{114}$.

La práctica de ver hasta los poros de las cosas se acompaña de una segunda operación: la pintura de la visibilidad de las cosas. La disección y la pintura de la anatomía encierran la bêtise en su propio laberinto; el lector-espectador queda atrapado sin salida. Impersonal, sin juicio ni opinión, disecar es una venganza que de cierta manera constriñe al lector a ver lo que ha estado y está frente a él.

Si el lector no saca de un libro la moralidad que debe encontrarse en él, es que el lector es un imbécil o que el libro es falso desde 112 Epístola enviada a G. Sand el 18 de diciembre de 1867.

113 Epístola a su sobrina Carolina del 9 de diciembre de 1876.

114 Epístola enviada a L. Colet el 16 de enero de 1852. 
el punto de vista de la exactitud. Porque, desde el momento en que una cosa es verdadera, ella es buena. Los libros obscenos, igualmente, no son inmorales más que porque les falta la verdad (Flaubert, 2007, p. 12) ${ }^{115}$.

La veracidad de la obra no pasa por el test un poco ingenuo de su correspondencia con lo real, de la correspondencia de la idea con lo real. La verdad de la obra se sitúa del lado de la perfecta visibilidad de las cosas en su aparecer. Se trata de que el libro solo pinte el aparecer de las cosas. Bajo esta perspectiva del pensamiento, que piensa la técnica de la obra, se entiende porqué en la obra de Flaubert no hay ni héroes ni monstruos. Sus criaturas son, y no son más ni menos, que las criaturas de la bêtise moderna del consenso de la cultura. La naturaleza del estilo es compleja: el estilo es un modo de pensar.

\subsection{Modo del pensamiento}

«El arte no se hace con el corazón sino con la cabeza» (Flaubert, 1980, p. 163) ${ }^{116}$; «[...] y ¿qué es el artista? ¿Si no es un triple pensador?» (Flaubert, 1980, p. 316) ${ }^{117}$. El artista piensa: «[... pues esas distinciones del pensamiento y del estilo son un sofisma» (Flaubert, 1980, p. 234) ${ }^{118}$. Y un año después afirma: « $\mathrm{El}$ estilo es la vida! ¡es la sangre misma del pensamiento!» (Flaubert, 1980, p. 427) ${ }^{119}$. El estilo es un modo de pensamiento constituido y definido por «[...] una manera absoluta de ver las cosas» (Flaubert, 1980, p. 31) ${ }^{120}$. Contemplar las cosas, es decir: suspender la producción de juicios vinculantes y subjetivaciones; las cosas se desatan de toda relación que rebase la visibilidad de su aparecer. Se trata de ver, solamente de ver las cosas. En su contemplación, el pensamiento se afecta a sí mismo, se despoja de la tentación de subyugar la visibilidad de las cosas bajo el poder de

115 Epístola enviada a G. Sand del 6 de febrero de 1876.

116 Epístola enviada a L. Colet del 25 de septiembre de 1852.

117 Epístola enviada a L. Colet del 26 de abril de 1853.

118 Epístola enviada a L. Colet del 12 de enero de 1853.

119 Epístola enviada a L. Colet del 7 de septiembre de 1853.

120 Epístola enviada a L. Colet del 16 de enero de 1852. 
las ficciones ontológicas y sus sendas lógicas, rompe con el orden del Ser y del mundo, con los discursos de verdad que fijan su ley y sustraen las cosas de sus movimientos históricos. Rompiendo con la apofántica, con el orden de significación y con su régimen de verdad, Flaubert construye el orden de la desvinculación, de la no-conveniencia. La relación de la no-relación deshace en el arte la imagen de la representación, de la mimesis platónica, y el sistema aristotélico de racionalidad de las reglas y las causas. En este modo de pensamiento, la contemplación reduce las cosas a lo elemental de su consistencia propia: la visibilidad de su aparecer. Las cosas no se pliegan sobre ninguna línea de inflexión exterior a la pura visibilidad de su aparecer.

Ahora bien, desde el siglo pasado, en el dominio de la literatura como disciplina, en la teoría y la crítica, es lugar común señalar a Flaubert como un punto de ruptura a partir del cual corre la historia moderna del arte de escritura; punto de inicio de la literatura propiamente dicha, de la escritura que revienta la función representativa a través de la operación de plegar el lenguaje sobre sí mismo. Poner fin a la función representativa de la escritura, dejar que el lenguaje se pliegue sobre sí mismo, que la palabra solo diga de sí misma, no es algo que va por sí ni se encierra en el interior de los bordes de la función de escribir. En Flaubert, un modo de pensamiento subyace en el estilo, conduce las operaciones artísticas y la producción de las obras de arte de escritura, dispone la forma de composición, la manera de su funcionamiento, el carácter de su fin y la misión de los efectos a inducir. En Flaubert hay un conjunto de ideas filosóficas que, aunque no siguen las instauraciones del sistema modular, están implícitas en sus obras y expresadas descosidamente en su correspondencia. Un pensamiento filosófico es el alma del cuerpo de su estilo de arte. «El novelista sabe lo que hace, filosóficamente hablando: substituir un orden por otro» (Rancière, 2010a, p. 114). Ni capricho narrativo, ni recurso de la ficción literaria, ni tampoco la elección de un libre arbitrio - que inclinaría a elegir esto mejor que aquello-; la substitución de un orden por otro es inmanente 
a un pensamiento otro: «[...] el sentido histórico es completamente nuevo en este mundo. Uno se va a poner a estudiar las ideas como hechos y a disecar las creencias como organismos» (Flaubert, 1991, pp. 16-17) 121 .

El estilo, manera absoluta de ver las cosas, designa ver todas las cosas todas como ellas son. En primer lugar, se consideran las cosas -en el capítulo dos se abordó la cuestión de la no existencia ontológica de estas-. El ser de las cosas no es una oculta nervadura esencial, las cosas no tienen profundidad esencial, ellas no son más, no son menos que su apariencia, la visibilidad de su aparecer. La cosa es pura visibilidad en su aparecer, detrás de la visibilidad de las cosas no hay nada. Consideremos ahora esa manera absoluta de ver. Ver de manera absoluta es ver lo que son las cosas en sí mismas, sus visibilidades. Esta manera de ver se define por una sola relación, la relación que se establece entre el ver y la visibilidad de las cosas, percepción de la manifestación visible de las cosas, sin poner en juego ninguna categoría ordenadora, sin ninguna relación de causalidad ni efecto. No se trata de la mirada subjetiva del artista ni de la absolutización de un ángulo de visión. No, no es un relativismo de la mirada subjetiva: se trata de una manera absoluta. Manera absoluta indica la completa desvinculación de las cosas de todo aquello que rebase la visibilidad de su aparecer.

Por consiguiente, la idea de la cosa no representa la cosa, la idea es la idea de la forma visible de la cosa; así, la forma visible de la cosa es inseparable de la idea de la cosa. En la obra de arte de escritura, «[...] escribir es ver, devenir ojo, poner las cosas en el puro medio de su visión, es decir, en el puro medio de su idea» (Rancière, 2010a, p. 106). En el poema en prosa de Flaubert, la frase no contiene ninguna idea, no representa ninguna idea ya que ella misma, la frase, es la idea de la cosa. Imposible la separación de idea y forma; puesto que «[...] la idea no existe más que en virtud de su forma. Suponga una idea que no tiene forma, es imposible; de igual manera una forma que no expresa una idea»

121 Epístola enviada a L. de Chantepie el 18 de febrero de 1859. 


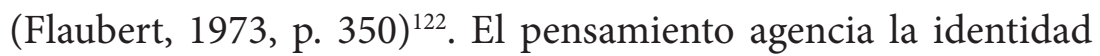
de frase e idea y cosa. La frase es la idea misma de la visibilidad de las cosas. Al respecto, Rancière (2010a) escribe: «[...] este estilo no es la soberanía del artífice de formas y de frases, la manifestación de la libre voluntad de un individuo, en el sentido en que se entiende ordinariamente. Es por el contrario una fuerza de desindividuación» (p. 108). Tal vez se podría decir — con cierta reserva- que, en la obra de arte de escritura, Flaubert opera una epoché: la frase es la suspensión del juicio, la desvinculación categorial; ella solamente es la pura visibilidad de las cosas en su aparecer. La manera absoluta de ver las cosas se sostiene por la capacidad de poder de no pensar categorialmente, lo que abre la vía al poder de contemplar la visibilidad de las cosas. En el polo opuesto, la bêtise moderna consistiría en la manera absoluta de no ver las cosas en la visibilidad de su aparecer. Esto es: someter las cosas al juicio, subjetivarlas, categorizarlas y fijarlas en una relación de causalidad y efecto. En sus obras, Flaubert jamás concluye ni juzga nada.

El planteamiento anterior conduce a señalar, esquemáticamente, algunos aspectos en relación con las ideas que sostienen porqué Flaubert desencadena un acontecimiento de la cultura, o sea, la atribución que se le hace de la paternidad responsable de la novela moderna o la literatura. Primero, rompiendo con el orden de la representación, Flaubert instaura una nueva poética en la que se libera la forma y la materia. La identidad de idea-forma-visibilidad de las cosas-frase, permite a Flaubert liberarse, y liberar al arte de la coacción del tema o la materia. Aquí se sitúa uno de sus sueños de artista: «Lo que me parece bello, lo que quisiera hacer, es un libro sobre nada, un libro sin atadura exterior, que se sostuviera el mismo por la fuerza interna de su estilo, como la tierra se sostiene en el aire» (Flaubert, 1980 , p. 31$)^{123}$. No hay materias propias del arte (idea que hoy subsiste en el régimen del arte; de cualquier cosa se puede hacer 
una obra de arte). También Flaubert se libera, y libera al arte, del régimen de la forma, dado que esta deviene en libre creación del artista. La forma del arte no es otra cosa que la creación de la belleza; y la belleza es el grado de perfección de la identidad de idea - forma - visibilidad de las cosas - frase-. La prosa del mundo caerece de belleza, el artista produce la belleza haciendo su poema en prosa. El artista dota de belleza las visibilidades de las cosas del mundo prosaico; pero desde el punto de vista de las cosas, solo las pinta, el poema hace coincidir su materia con la bêtise del mundo.

El tiempo de la belleza ha pasado, los grandes clásicos no eran artistas sino poetas. Si ya no es el tiempo de la belleza, hay que ser artista, hay que producir la belleza. Flaubert artista crea el poema en prosa y lo hace coincidir con la prosa del mundo prosaico: la materia del poema en prosa es la misma materia de la prosa del mundo (la bêtise moderna): identidad entre el poema y el mundo. Ahí, la individualidad del artista se disemina en el mundo, la obra es impersonal; y, a la vez, está presente el autor como creador de la belleza del poema. «La presencia del artista en su obra [...] consiste en su diseminación. Consiste en ser el medio de esta disolución. El estilo es un quehacer de frases solo porque él es de entrada un quehacer de "concepción"» (Rancière, 2010a, p. 108).

El estilo de Flaubert se constituye como el equivalente del poema substancial, de ese poema que Homero escribía como individuo y a la vez como libro de la vida de un mundo colectivo en el que se borra la individualidad del artista. Segundo, para Flaubert, «El arte griego no era un arte, era la constitución radical de todo un pueblo, de toda una raza, del país mismo [...]. El tiempo de lo bello ha pasado» (Flaubert, 1980, p. 76) ${ }^{124}$. Pensando lo impensado del pensamiento del arte, Flaubert niega a los grandes creadores del pasado el estatuto de artistas; en el tiempo de lo bello, el creador era poeta sin ser artista. Bajo esta

124 Epístola enviada a L. Colet el 24 de abril de 1852. 
línea de fuga, dice: «[...] lo que hay de prodigioso en Don Quijote es la ausencia de arte [...]» (Flaubert, 1980, p. 179) ${ }^{125}$. La vida y el espíritu de los creadores de otros tiempos era «[...] el instrumento ciego del apetito de lo bello, órganos de Dios, por los cuales él se probaba a sí mismo» (Flaubert, 1973, p. 283) ${ }^{126}$. Ahora, cuando el mundo carece de belleza, empieza el tiempo del arte.

Lo que nos resta es el exterior del hombre, más complejo, pero escapa con ventaja a las condiciones de la forma. También creo que la novela, que acaba de nacer, espera su Homero. ¡Qué hombre hubiese sido Balzac si hubiese sabido escribir! Pero no le ha faltado sino eso. Un artista, después de todo, no habría hecho tanto, no habría tenido esa amplitud (Flaubert, 1980, p. 209) ${ }^{127}$.

En los tiempos sin arte, la belleza del poema emanaba de la interioridad de la espiritualidad del pueblo. En el mundo moderno hay solamente exterioridad, toda referencia a la interioridad o al fondo espiritual del mundo es imposible. El arte solo puede ser arte del exterior del hombre, de la visibilidad de conductas sin profundidad. Mas una ventaja emerge: la forma se libera de los patrones que la coaccionaban haciéndola depender de la sustancialidad del mundo y del orden colectivo de un pueblo. Cuando Flaubert considera que Balzac no sabe escribir, no se trata de una objeción, sino más bien de un elogio. Balzac, como nadie, aprehende el exterior del hombre; mas no es artista, no logra producir la forma, la belleza. No logra la identidad entre un mundo prosaico sin profundidad y la bêtise de las conductas individuales. Si ya ha pasado el tiempo de lo bello, hay que ser artista. El artista se sitúa en la época de la separación, en el tiempo histórico en que la mirada que apunta a la Idea abstracta está radicalmente separada de aquella idea que lleva a la prosa del mundo. El estilo de Flaubert procura una salida a esa separación como cuestión en la cual se juega o bien la muerte del arte o bien el devenir del arte moderno. Rancière (2010a) escribe:

125 Epístola enviada a L. Colet el 22 de noviembre de 1852.

126 Epístola enviada a L. Colet el 8 o 9 de agosto de 1846.

127 Epístola enviada a L. Colet el 16 de diciembre de 1852. 
[...] hay (habría) que hacer una poesía enteramente intencional, enteramente deseada, que sea el equivalente romántico de las obras poéticas clásicas, las cuales no eran tales más que porque ellas no eran deseadas, porque el producto de la intención del artista se identificaba estrictamente con el proceso inconsciente de producción de la obra [...] Flaubert suministra su respuesta al dilema hegeliano [...] (p. 104).

En esta línea de fuga, Flaubert encuentra una salida a la muerte del arte o al dilema del arte planteado por Hegel. Su pensamiento estético no es extraño a las posiciones del romanticismo alemán ni a la problematización estética de Hegel, donde está en juego la posibilidad o la muerte del arte del siglo XIX. El romanticismo ha roto con los patrones del arte representativo instaurando una nueva poética, sus elementos son retomados por Hegel y usados para proclamar la muerte del arte. En sus Lecciones sobre la estética, el filósofo, por una parte, opone el clasicismo griego al arte romántico moderno; opone la unión de la naturaleza y el espíritu -la expresión sin voluntad de arte en la antigüedad griega - a la moderna poesía de la separación sostenida como una actividad particular frente a un mundo prosaico y hostil. Hegel considera el romanticismo alemán como empeño en perpetuar la literatura mediante el esfuerzo por articular la poesía y la prosa, de conciliar el Espíritu y el Mundo; mas tal empresa resulta vana. Tal tentativa sería el esfuerzo de poetizar el mundo de la mediocridad.

El artista moderno usa un lenguaje separado del mundo prosaico que, desdivinizado, carece de poesía y además es incapaz de recibirla. Así, el artista, tomando sus distancias respecto al universo representado del mundo prosaico, solo muestra la soberanía de su subjetividad, mientras que la obra deviene en una fantasía sin peso ni objeto. "Bajo su forma objetivista, el poema novelesco se pierde en la prosa del mundo burgués. En su versión subjetivista, lleva la obra a la sola exhibición del signo de la muerte del arte, a la signatura del artista» (Rancière, 2010a, p. 71). El nacimiento de la subjetividad soberana del artista es la muerte del arte. Haciendo valer su subjetividad, el artista ejerce 
un voluntarismo que marca la obra de arte con su sello personal $y$, por ende, su palabra no corresponde al espíritu de un pueblo. Suscitando una poesía de la cual el mundo está desprovisto, no puede alcanzar lo Bello, que se producía en el clasismo sin voluntad subjetiva de artística y en coherencia con un mundo espiritualizado.

En el clasicismo griego, la obra de Homero es la epopeya de un pueblo, el canto de un pueblo divinizado, poetizado, que no conoce la separación entre la forma de vida colectiva y la enunciación poética. Un pueblo hace un poema, un poema hace un pueblo (Rancière, 2010a). Ahí reina la unidad épica de los modos de hacer; lo que hacen los hombres es inseparable del mundo colectivo, originalmente poético. Ese mundo es poético, y no prosaico: adecuación exacta entre un modo de ser colectivo y el modo de ser individual. El poeta como sujeto individual se borra, se disuelve en la dimensión colectiva; mas, a la vez, la obra poética es de un individuo que la compone. Homero escribe su poema como Ulises hace su cama matrimonial, así el poema puede ser al mismo tiempo un libro de vida tallado en el tejido colectivo de la vida del pueblo y una obra individual de un artista, cuya subjetividad está a la vez diseminada en el modo de ser de la colectividad. La epopeya clásica era el poema que manifestaba la perfecta unidad del genio creador y la poeticidad inherente a la vida de un mundo colectivo (cf. Rancière, 2010a, p. 63). Allá, la poesía no era una representación de dioses y héroes, la no separación de la vida y el poema constituyeron una perfecta armonía que, sin representación, definió el clasicismo. Por otra parte, Hegel retoma del romanticismo su programa del futuro, ve en él nada más y nada menos que la misma forma del clasicismo griego. Por consiguiente, la homologación es el juego de su anulación. El filósofo traspasa (retrospectivamente) la teoría de la poética del romanticismo al clasicismo, transforma la poética futurista del romanticismo en su teoría del arte griego. 
Hegel generaliza en efecto la paradoja de ese clasicismo romántico. Para que la idea se manifieste y desaparezca al mismo tiempo la forma del arte, se necesita la exacta coincidencia entre lo que el artista quiere hacer y lo que no quiere hacer, lo que hace sin saberlo ni quererlo (Rancière, 2010a, p. 65).

En esta operación, el filósofo hace del programa del advenir del romanticismo algo del pasado, el retorno futuro del clasicismo (Rancière, 2010a). Entonces, el romanticismo aparece como una especie de clasicismo que comporta la autoconciencia de su propia poética. La proclamación de la muerte del arte se sitúa en el intento de la poesía por sobrepasarse ella misma y devenir su propia conciencia; ahí, ella no haría otra cosa que salir del dominio del arte, mas sin alcanzar el de la filosofía. El sentido histórico del espíritu bloquea el porvenir del arte. Pero, en el caso de Flaubert - como se consideró anteriormente-, es el sentido histórico - y no precisamente igual al de Hegel- que deviene en la mayor posibilidad del arte y de un modo de pensamiento. Modo de pensamiento radicalmente opuesto a la concepción de la naturaleza platónica y aristotélica (que había dominado la imagen del pensamiento y las maneras de pensar de la cultura occidental).

Ahora bien, Rancière ve en el pensamiento del estilo de Flaubert una respuesta a la problematización del arte de Hegel; mas también considera que la manera absoluta de ver las cosas se soporta sobre una metafísica. El pensamiento de Flaubert apropia ciertos trazos de Spinoza (de un espinosismo que le llega a través de las modulaciones del romanticismo): un mundo substancial en el que las cualidades de las cosas no se separan de su ser, un mundo en el que las individualizaciones son solamente las afecciones de la substancia, afecciones que no pertenecen o no son propiedades particulares de los individuos. La vida no comporta razones, no tiene sentidos, ni particulares, ni universales; el mundo solo es un fluir sin término, una agitación infinita de átomos que conforma y deshace configuraciones, el mundo fluye sin sujetos ni objetos. 
Rancière ve en las explicaciones que el diablo espinosista da a Antonio, en la primera versión de La tentación, el pensamiento del mundo que Flaubert ha apropiado de Spinoza, pensamiento constitutivo de su estética. El diablo lleva al buen eremita en un viaje por el espacio, le hace respirar el aire del vació y, después, ver las cosas en su plenitud absoluta; mas el vacío es el ser mismo de las cosas, el ser no se diferencia de sus atributos, no se separa de las cualidades ni las determinaciones de la potencia de lo indeterminado. «La tentación metafísica del santo da los principios exactos de la poética del estilo absolutizado» (Rancière, 2010a, p. 108). El estilo deviene una manera absoluta de desindividuación, donde no hay lugar ni para el sujeto ni para el objeto. Las individuaciones no son otra cosa que afecciones de la substancia, no pertenecen a los individuos, sino que componen - al azardiversas configuraciones. Átomos que se entrelazan, se separan, se retoman en una vibración absoluta. "La manera absoluta de ver las cosas es la capacidad de manifestar esta vibración [...]» (Rancière, 2010a, p. 108).

Bajo otra pendiente, se podría considerar que la poética del estilo absolutizado nace de la bêtise formidable (ver capítulo dos) que procura a Flaubert los elementos necesarios para componer la tentación metafísica del diablo. En La tentación, la bêtise aparece existiendo ontológicamente: cuando el buen eremita habiendo visto lo originario, quiere ser la materia bajo todas sus formas, $\mathrm{o}$ sea, la materia sin ninguna forma quiere ser la bêtise de la materia. No obstante, toda La tentación toda no es otra cosa que la noche delirante de San Antonio. Los delirios están en el pensamiento del buen eremita, tal como el diablo se lo dice, al final de la primera versión de la obra: «Volveré, porque estoy en tu corazón y en tu cabeza» (Flaubert, 1908, p. 530). Bajo otra formulación, en la última versión, se encuentra la misma idea, cuando el mal discípulo Hilarión, que el buen eremita cree que lo ha abandonado mucho tiempo atrás (y que luego se transformará en un diablo filosófico y espinosista), le dice que nunca lo ha abandonado, porque siempre ha estado en él. Por lo tanto, la existencia o el 
ser de una materia sin determinación, en su plena brutalidad de movimiento, es un delirio, una ilusión del pensamiento que tienta al pensamiento. El pensamiento se tienta a sí mismo. Escéptico, sin fe, sin «creer en nada», sin metafísica, Flaubert asume el movimiento perenne de las cosas, y lo asume a la manera de la física moderna (todo permanece en movimiento mientras algo no le haga resistencia). Flaubert es consciente de que se trata de un pensamiento del pensamiento - es consciente de que no se trata de una esencialidad metafísica-. Lo real es irracional y lo racional no es lo real.

El poema en prosa es posible porque la "prosa del mundo" no es ella misma más que el orden superficial en el que se efectúa la potencia del gran desorden. No hay que "repoetizar" la realidad prosaica. Esta presenta ella misma su disolución a la mirada atenta. El mundo se va él mismo en frases singulares. (Rancière, 2010a, p. 109).

La problemática relación de lo objetivo con lo subjetivo, de lo consciente con lo inconsciente, de lo colectivo con lo individual (a partir de lo cual Hegel opone la poética del clasicismo a la fantasía del romanticismo) es declinada por Flaubert en la relación del estilo con la manera de ver. Los órdenes racionales del mundo prosaico son solo superficiales, su fondo efectivo y su operador es la potencia del desorden, la fuerza de relación de las no-relaciones; por lo tanto, el poema en prosa de Flaubert no requiere re-poetizar el mundo prosaico, su misma realidad hace visible su disolución. El estilo coincide con la realidad del mundo mismo. Ese quehacer de concepción, modo de pensamiento, transforma la manera de la ficción en las obras de arte de escritura al borrar la ontología que subyace en el sistema representativo.

Llega el momento de concluir este segmento. Frente a la bêtise del siglo XIx, Flaubert deviene en pensador y desmoralizador. Este papel se hace efectivo mediante un decir de la verdad - horrible, cruel, desnuda-. Mas este solo se puede jugar si está amarrado estrechamente con el papel del pensador - que es indistinguible 
de un modo de ser del pensamiento y del estilo de arte inmanente a él-. Sin duda, uno no escapa a su siglo, no se está en un afuera a la historia que constituye nuestro modo de ser, es decir, de pensar, sentir, decir, actuar. No obstante, Flaubert, militando contra el modo de ser del siglo XIX, contra sus maneras de vivir $\mathrm{y}$ sus discursos; hace jugar a la verdad otro juego con otras reglas. $\mathrm{Su}$ juego contra-cultural pretende inducir efectos de contraconducta. Pero no se trata de un juego teórico que prometería una mejor sociedad, que promovería el remiendo del tejido del consenso ético de su época; el artista escéptico se incapacita frente a la promesa del progreso y se prohíbe cualquier tipo de «deber ser». Su juego contra-cultural alcanza su real como cosa hecha. Con raíz en su modo de vida y su modo de pensamiento, sus obras de arte de escritura son una práctica de veridicción, práctica de un decir verdadero que devuelve a la cultura su propia verdad cínica. La ética de la verdad de Flaubert no es más, no es menos que la práctica de la verdad del arte y de la verdadera vida en la plástica de su existencia y de sus libros. Vida-artista: experiencia histórico-crítica de la vida; experiencia histórico-crítica de la bêtise moderna. 


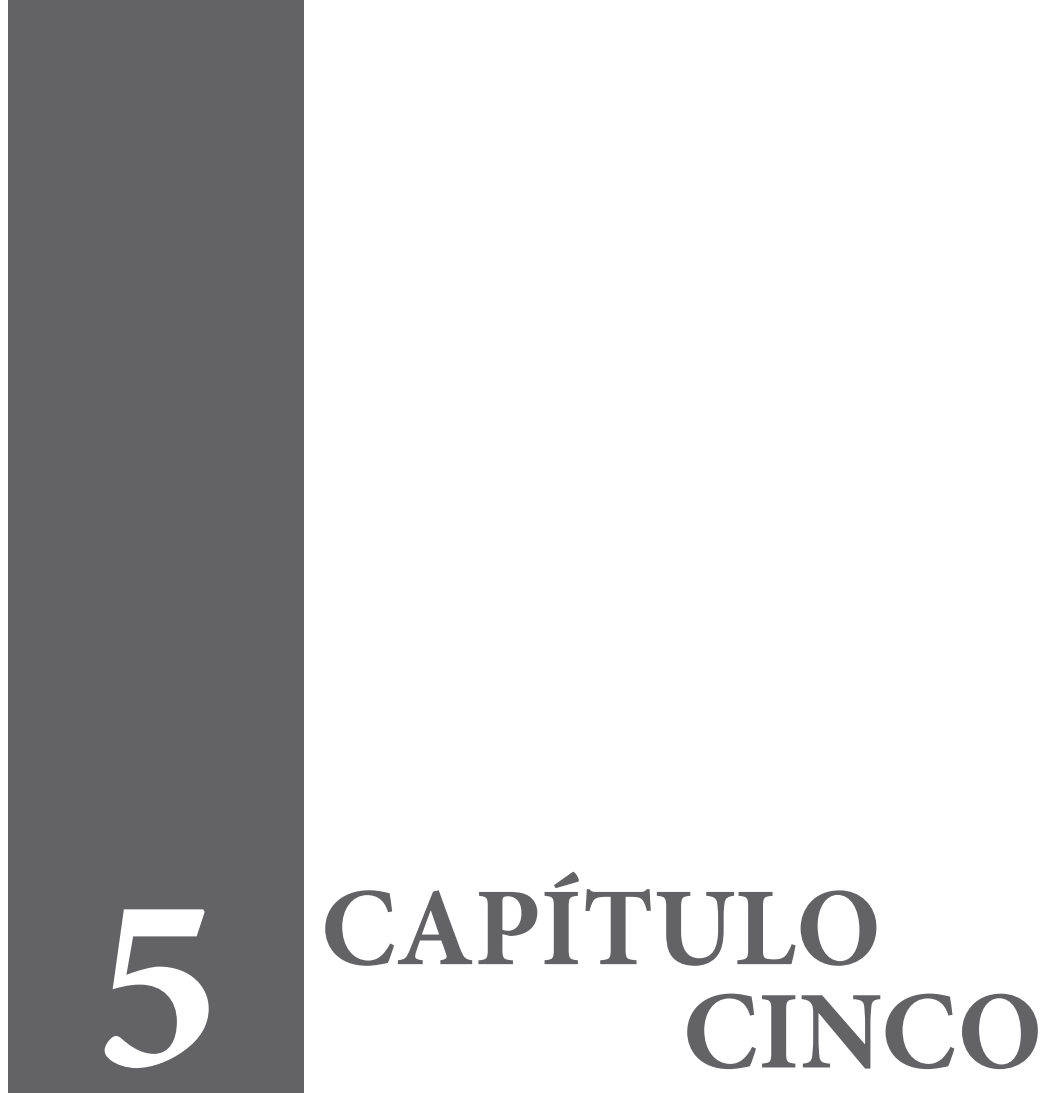





\section{Alethurgias}

¡Un día más! ¡Ya ha pasado otro día!

¡A pesar de todo, antaño yo no era tan desdichado! [...]. A horas fijas dejaba mi trabajo; y rezando con los dos brazos extendidos sentía como un manantial de misericordia que se derramaba de lo alto del cielo en mi corazón. Ahora se ha secado. ¿Por qué? (Flaubert, 1983, p. 52).

En su melancolía, esas palabras de Antonio abren el primer monólogo de La tentación de san Antonio-. "iOh felicidad!, ¡felicidad!, yo he visto nacer la vida [...]. Yo quisiera [...] acurrucarme bajo todas las formas, penetrar cada átomo, descender hasta el fondo de la materia, ¡ser la materia!» (Flaubert, 1983, p. 237). En su éxtasis, esas palabras del buen eremita cierran su último monólogo. Cuando Antonio ya ha sufrido todas las tentaciones posibles, incluida la tentación metafísica del mundo y de la verdad de la verdad - operada por un diablo spinozista-, encuentra su salvación en la brutalidad de la materia; se corren 
los velos del tabernáculo y el oro de la nueva aurora pone fin a su noche melancólica. En otro escenario, casi al inicio de Bouvard y Pécuchet, los dos buenos imbéciles

[...] glorificaron las ventajas de las ciencias: ¡cuántas cosas por conocer! ¡cuántas $[s i c]$ investigaciones — si se tuviera tiempo-! Desgraciadamente, el ganarse el sustento los absorbía; y alzaron los brazos de asombro, casi se abrazan por encima de la mesa al descubrir que eran todos dos copistas, Bouvard en una casa de comercio, Pécuchet en el ministerio de la marina, - lo cual no le impedía consagrar, cada noche, algunos momentos al estudio(Flaubert, 1979, p. 55).

$\mathrm{Y}$ en el escenario de las conclusiones del libro, sus voces hacen resonar su estupidez: «- ¿¿Qué vamos a hacer?”- ¡No reflexión! ¡copiemos! [sic] Es necesario que la página se llene, que "el monumento" se complete [...] igualdad de todo, del bien y del mal, de lo bello y de lo feo, de lo insignificante y de lo característico. Lo único verdadero son los fenómenos» (Flaubert, 1979, p. 443). Cuando los dos buenos imbéciles han fracasado en las experiencias de llevar los saberes modernos - sus teorías y tecnologías - al uso de sí mismos, deciden abandonar todo nuevo intento de estudio, de reflexión y uso de saberes. Un conocimiento han alcanzado: «todo es igual». Si no hay diferencias específicas, cualquier práctica es igual a otra. Los discursos de la verdad son un exceso adicionado a las prácticas. Se aplicarán a un uso de lo irracional, dedicarán sus vidas a copiar, llenarán la página y completarán el monumento de la bêtise moderna. En La tentación, el tiempo de la ficción va de la melancolía de Antonio - que lo habita al empezar la noche - al éxtasis del eremita que lo estremece cuando adviene la nueva aurora-. En Bouvard y Pécuchet, el tiempo de la ficción va de la glorificación de las ciencias - cuando se conocen los dos copistas- a la decisión radical de solo copiar los discursos - tras el reconocimiento del fracaso del uso existencial del conocimiento-. En estas dos obras, la ficción, rodando sobre las relaciones de la verdad con la vida y la manifestación visible de la verdad en la vida, se cierra 
gravemente con la visibilidad de una de alethurgia de la bêtise, de su manifestación visible en la vida. Mas, en el cierre, un efecto es inducido: el lector descubre que toda la obra ha sido el despliegue de la visibilidad de la bêtise en la vida. La ficción instaura una performance de la bêtise que, partiendo de un momento cero, hace un bucle y se cierra en el mismo punto de partida. El bucle instala el tiempo y el espacio de la anatomización y exhibición de la bêtise - otro tanto podría considerarse en los casos de las otras novelas de Flaubert-. Examinar el modo de la alethurgia de la bêtise (la manifestación visible de la bêtise en la vida) y los efectos que induce es el propósito del presente segmento.

\subsection{Tentaciones}

La vida ascética del humilde Antonio ha devenido en personaje y en tema del pensamiento en la cultura occidental. De la doctrina de este poco o nada se ha ocupado la historia, mas su estilo de vida - como testigo de la verdad - ha sido tratado en diversos dominios y géneros. San Antonio es el hombre de las pruebas y el nombre de las tentaciones de una vida ascética, no dilapidada y centrada en el uso de sí mismo. Ahí está el anclaje del título de numerosas obras, tal es el caso del libro de Flaubert -en cuyas fuentes se destaca la pintura La tentación de san Antonio de Brueghel, pintura que el novelista pudo ver en el palacio Balbi, en Génova-. De La tentación san Antonio, atesta su autor: «[...] es la obra de toda mi vida» (Flaubert, 1998, p. 531) ${ }^{128}$.

Seis años antes de su muerte aparece la última versión de ese libro, cuya prehistoria data de cuarenta años atrás y se recoge en los grafismos de sus escritos de juventud. «La tentación ha existido antes de todos sus libros». Las relaciones entre verdad y vida lo han mortificado en las Memorias de un loco, en Sueño de infierno, en Danza de los muertos, en Smahr y en Recuerdos, notas y pensamientos íntimos. Obra de una vida por su longitud cronológica: al menos que su composición no envuelva la

128 Epístola enviada a L. de Chantepie del 5 de junio de 1872. 
preocupación existencial por la bêtise y que no vaya a la par con la creación de un modo de pensamiento; al menos que el estilo sea separable de la existencia de Flaubert; al menos también que el libro no sea una práctica alethúrgica. La tentación de San Antonio tiene raíz en la existencia de Flaubert, y tan profunda que, en su primera versión, la subjetividad del autor ha sido el personaje, mientras que la última -impersonal- se sostiene sobre su pensamiento filosófico de la verdad y de la vida. Esta obra de arte de escritura es un tipo muy particular de alethurgia que, haciendo visible la relación de la verdad con la vida, en su espesor, pone en cuestión los regímenes de verdad fijados en la cultura y desborda las formas de vida.

Se abre el libro, sin prólogo ni mediación alguna, el poema en prosa toma la forma de un teatro y lanza al lector a la posición de espectador ${ }^{129}$. De entrada, la didascalia pone ante sus ojos la descripción del lugar donde habita Antonio, de su porte y sus gestos, que, con precisión y en pocas palabras, hace visible el estilo de vida del eremita. Identidad de frases, visibilidades, ideas, formas. El primer monólogo de Antonio hace visible el estado de su alma al ocaso del día («hora sexta»). La acidia lo habita. En la escena de exposición ha empezado simultáneamente la dramaturgia. La tentación es un teatro alethúrgico complejo que, en su espesor, guarda otras dramaturgias, unas en el interior de otras. El teatro hace visible la forma de vida de Antonio y el contenido refrenado de su corazón y su pensamiento. A través de sus delirios acidiosos, el lector-espectador ve otros personajes y otra alethurgias puestas ante los ojos; La tentación pliega y despliega alethurgias y discursos de la verdad de la verdad en la alethurgia del eremita. En los cruzamientos de los juegos de regímenes de verdad y maneras de vivir, La tentación opera una disección de la bêtise, su anatomía toda se exhibe ante los ojos del lector-espectador. Su sistema de ficción es espeso, su dispositivo instaura el tiempo de narración como una performance; un sistema de racionalidad efectivo que, partiendo de un punto cero, forma un bucle el cual se cierra sobre su mismo punto de emergencia.

$129 \mathrm{Al}$ respecto, el trabajo de Foucault (2001d) sobre La tentación es incontestable. 
El tiempo va del ocaso del día, marcado por el final de una jornada, al final de una noche aciaga, marcada por el inicio de otra jornada, que no se diferencia de aquellas que la han precedido monótonamente. La longitud temporal es la duración de la acidia (o melancolía) del eremita, empieza con su irrupción y termina con su disolución. Ahí, la performance induce un efecto sobre el lector-espectador a través de un precepto: cuando termina la noche acidiosa, la nueva aurora abre la continuidad de la manera ascética de la vida del eremita como otrora, sin embargo, algo ha cambiado: la verdad de la verdad se ha transformado, queda inscripta bajo el signo de jser la materia!, furor que lanza hacia la bêtise «formidable y universal». La felicidad de haber visto nacer la vida engendra en Antonio el deseo de ser la materia; entonces, como si corrieran las cortinas de un tabernáculo aparece el disco solar y en su interior el rostro de Jesucristo se hace visible. El efecto inducido por el dispositivo de ficción - mediante su bucle temporal- remite a la gran tentación del pensamiento nihilista del siglo XIX: ¿cómo es posible una vida sin verdad? En el bucle, en el presente de la noche melancólica y delirante, se envuelve el tiempo de los fantasmas de la historia del mundo oriental y del mundo occidental. El flujo va del milenario Oriente al antiguo Occidente, y de la antigüedad occidental a las brumas teológicas del cristianismo de los primeros siglos, donde la imaginación sobrepondrá en el presente, el futuro devenir de los problemas de la verdad y la existencia de los tiempos modernos.

En el espacio de esta noche de Egipto que persigue el pasado del Oriente, es toda la cultura de Europa que se despliega; la Edad Media con su teología, el Renacimiento con su erudición, la edad moderna con su ciencia del mundo y de lo vivo. Como un sol nocturno, La Tentación va de este a oeste, del deseo al saber, de la imaginación a la verdad, de las más viejas nostalgias a las determinaciones de la ciencia moderna [...] y como un pliegue del tiempo [...]. Uno está en el vacío de la historia [...]. La "tentación" de san Antonio es la doble fascinación del cristianismo por la fantasmagoría suntuosa de su pasado y las adquisiciones sin límites de su advenir (Foucault, 2001d, p. 335). 
En el juego de sus zurcidos temporales, el libro induce varios efectos: el régimen moderno del saber de conocimiento desmonta la verdad sobre la que se pliega la forma de vida de espiritualidad antigua y medieval, la despoja de la verdad que la conducía y la sostenía. No obstante, en ese mismo desafío, el conocimiento elevándose al infinito, rebasando sus límites, deshace su propia verdad. Un diablo spinozista, "corifeo del saber occidental», conduce al buen San Antonio a la dimensión de un tipo de nihilismo en el que se deshace el régimen del saber de espiritualidad y el régimen del saber de conocimiento. Por consiguiente, la forma de vida queda desatada de su nudo con la verdad. El dispositivo de ficción dispone la suite del teatro alethúrgico en tres momentos, en tres series subyacentes.

\subsubsection{La chrêsis de la ascesis}

Haciendo uso de la vida ascética en su verdad, y siguiendo el camino de su salvación, Antonio se afecta a sí mismo. ¿Cuál es el precio que Antonio ha de pagar por su salvación, es decir: ¿cuál es el precio ascético de la verdad? Por chrêsis se entiende la preocupación o el uso de algo en el que el individuo usando ese algo se afecta a sí mismo (ver capítulo uno). Ascesis designa, bajo el sentido antiguo del término askesis, el trabajo que un individuo efectúa sobre sí mismo para transformarse y alcanzar un modo de ser determinado que lo conduce a una verdadera vida. En su gravedad pura, la askesis es un tipo de chrêsis, un uso de sí mismo. En el pensamiento antiguo, una vida otra solamente se puede alcanzar a través del acceso a la verdad, acceso que, como compensación, transfigura la vida asegurando la salvación del sujeto. La ascesis, como práctica continua de retirar la mirada de la distracción mundo prosaico para dirigirla y fijarla en la verdad, implica una tensión constante, un desafío permanente, un combate sin tregua con ciertas maneras de vivir, con las pasiones, los deseos, las inclinaciones, etc. Negativamente, las amenazas constituyen la razón de ser de esta práctica; mas si las fuerzas de distracción, aunque gobernadas, son susceptibles a irrumpir de 
nuevo en la vida, la ascesis ha de abarcar la vida toda. Durante toda la vida se ha de pagar el precio de la verdad. ¿Cuál es el precio que uno ha de pagar para acceder a la verdad? ¿Qué deseos se han de refrenar, a qué partes de uno mismo se debe renunciar para alcanzar la verdadera vida?

De la poblada llanura prosaica de los otros a la cima solitaria de su montaña sagrada, Antonio ha sido conducido por su ascesis. Ahí, en la Tebaida, situada en lo alto de una montaña cerrada por gruesas piedras, vive el eremita en su soledad. La obra describe el habitáculo de Antonio, su porte y gestos, pone ante los ojos del lector-espectador lo elemental de su manera de vivir: un cántaro para el agua, un pan negro; una estela con un único libro; esparcidos en el suelo, unos hilos de esparto, unas pocas esteras, una cesta, un cuchillo; largos sus cabellos y su barba, cubierto con una túnica de piel de cabra, sentado con las piernas cruzadas, teje esteras. Antonio ha llevado su vida a la reducción extrema de lo elemental. Reducción que, a la vez, es ampliación de la misericordia divina; soledad que, a la vez, es, gran compañía de la gracia divina. Como actitud, la reducción de la vida a lo elemental es el nivel máximo de desposesión posible y real; pues, todo aquello que rebasa lo elemental es superfluo, un exceso amenazador para la atención que se fijada en la verdad; una vida en su pureza elemental, sin mezcla, hace seguro el camino de la verdadera vida, vida en la verdad, por la verdad, para la verdad. Como conducta, la reducción de la existencia permite equiparse de lo necesario para enfrentar las amenazas que se ciernen sobre la manera de vivir en uso. Fuente de perturbación, dislocación y extravío de la verdadera vida, es todo agregado a un cántaro de agua para calmar la sed, a un pan negro para alimentarse, a una estera para dormir, a una piel de cabra para cubrirse; agregado inútil es tener más que un cuchillo y un punzón para trabajar y más que el pan para el trueque; agregado inútil es tener un libro más al lado de la sagrada escritura, el libro de la verdad; y también, la compañía de otros, su conversación, sus afectos, su admiración y la venganza. 
En suma, se trata de vaciar la vida de lo superfluo para colmarla de toda la verdad que es capaz de contener. Desprenderse de los bienes, valores y deseos comunes en las vidas ordinarias, es decir: desubjetivarse del mundo prosaico para prenderse a la verdad.

La primera serie de tentaciones cae sobre todo lo que rebasa lo elemental de la vida, ellas ponen a prueba el trabajo que, sobre sí mismo, ha efectuado el eremita para alcanzar su salvación. En el espesor de la amarga acidia, la ascesis de Antonio es puesta a prueba. Al caer la noche, en su alto retiro del mundo, en su aislamiento abierto, el eremita se contrista.

¡Un día más! ¡Ya ha pasado otro día!

¡A pesar de todo, antaño yo no era tan desdichado! [...]. A horas fijas dejaba mi trabajo; y rezando con los dos brazos extendidos sentía como un manantial de misericordia que se derramaba de lo alto del cielo en mi corazón. Ahora se ha secado. ¿Por qué? (Flaubert, 1983, p. 52).

Como las miles de jornadas que le han precedido, ha transcurrido ese día. Sin embargo, su ocaso es como ninguno: el buen Antonio se melancoliza en su Tebaida. En La tentación no hay ningún rastro de otros episodios melancólicos anteriores; una noche plétora de delirios es suficiente para el plan de la ficción literaria. El dispositivo de ficción sobrepone «el mal del siglo» de Flaubert sobre la acidia anacoreta de fines de la antigüedad. Sin fricciones, la operación es posible en cuanto varios rasgos característicos de la acidia antigua - con ciertas modificaciones históricas que no alteran lo fundamental一, se han alojado en la melancolía del siglo xIx: tristeza profunda, desesperanza y angustia; pérdida de interés y desvalorización o desprecio por las cosas que se tienen o se hacen; ensimismamiento, ensoñaciones, delirios.

Entre fines del siglo III y el correr del siglo Iv, la práctica del ascetismo cristiano alcanza su límite extremo en la figura del anacoreta del desierto. Desprendido de todo bien material, 
cubierto con una rústica piel o túnica, sin casa, ni familia, ni amigos; en su soledad el anacoreta se pone a prueba a través de su grave ascesis. Esta figura cristiana de la desposesión extrema y de la soledad íntegra se somete a las pruebas de todo aquello que atañe a su cuerpo (pasiones, lujuria, inclemencias climáticas, etc.). El mayor desafío que enfrenta la ascesis del anacoreta es la tentación de los demonios, que juegan con sus pensamientos e imaginación para extraviarlo de la vía que lo conduce a Dios.

Asentándose en este último tipo de pruebas, muy pronto en el cristianismo se ve surgir un azote moral sin precedentes: la acidia. La palabra latina acedia procede etimológicamente del término griego akedia -en el que el prefijo privativo (a) designa la negación de kedos, "preocupación, cuidado»- con el cual se designaba el rechazo a la preocupación de los otros y a la preocupación de sí que se hacía patente en la negligencia, la indiferencia y el abandono de los muertos sin sepultura. Sin embargo, la retoma cristiana del término conduce su campo semántico a una acepción especializada: la acidia deviene en una enfermedad crónica del alma inducida por el diablo o que da cabida al diablo. Acedia, tristitia, taedium vitae, disidia son las denominaciones que los padres de la Iglesia dieron al azote moral del alma que sufrían los anacoretas del desierto. Como una peste, rápidamente la acidia pasó del desierto a los monasterios, y seguidamente se extendió entre los laicos de toda Europa. En sus precarios inicios, esta afección moral no estaba relacionada en absoluto con la melancolía - con la bilis negra cuyo desorden cuantitativo y cualitativo producía efectos nefastos en los comportamientos, pensamientos y estados anímicos-, ni con la astrología, ni con la posibilidad de la genialidad. Los avatares de varios siglos de historia fueron necesarios para que se entrecruzaran, homologaran o complementaran la acidia y la melancolía ${ }^{130}$ - en sus sintomatologías, etiologías y consecuencias, 130 «No es fácil precisar en qué momento la doctrina moral del demonio meridiano salió de los claustros para fundirse con el antiguo síndrome médico del temperamento atrabiliario. Sin embargo, cuando el tipo iconográfico del acidioso y del melancólico aparecen fusionados en las ilustraciones de los calendarios y de los almanaques populares a fines de la Edad Media, el proceso debía estar ya iniciado desde hacía tiempo [...]» (Agamben, 2006, p. 41). 
como también en sus tratamientos teológicos y terapéuticos y en las composiciones artísticas-. Otros avatares de historia borrarán la acidia y despojarán la melancolía de sus lazos humorales, para situarla en la soberanía de su triste reino. Los primeros textos sobre la acidia, documentos fundadores, proceden de los padres de la Iglesia, entre los siglos IV y v. Esos discursos de la verdad de la acidia se enfocan en la vida monacal y están dirigidos principalmente a ella, mas se extienden al anacoretismo, como en segundo plano.

«Demonio de medio día» es una de las denominaciones de la acidia desde los primeros siglos de la Edad Media, pues el demonio empieza su trabajo a partir del sopor que invade al asceta al empezar la tarde. Pero la hora propia de la eclosión es la hora sexta, cuando llega el ocaso. O bien la acidia abre el camino al demonio o bien la acidia es causada por el demonio, de todos modos, en ella tiene lugar su obra, dado que allí, el demonio juega con los pensamientos, los recuerdos y las imaginaciones del asceta. Se infiere entonces que si la ascesis es el camino que lleva hacia Dios, los objetos privilegiados del mal serán todos aquellos que la trastocan, recogidos en los llamados siete pecados capitales. Al jugar con la imaginación, las afecciones y el pensamiento, el demonio hace que el asceta se sienta incapaz de continuar el duro camino hacia el bien divino y, a la vez, recordando e imaginando el abandonado mundo prosaico con sus placeres y comodidades, se siente incapaz de retomarlo. Si hay una incapacidad para retornar a la forma de vida prosaica es porque el acidioso ni ha olvidado ni ha cesado de desear el bien divino. Sin faltarle el deseo de alcanzar la salvación, a este le falta el camino a la salvación, la fuerza para sostener su ascesis. El recessus a bono divino del acidioso indica no la falta del objeto, sino la imposibilidad de alcanzarlo: «[...] perversión de una voluntad que quiere el objeto, pero no la vía que conduce a él y desea y yerra a la vez el camino hacia el propio deseo» (Agamben, 2006, p. 31). La tensión polar entre el deseo de alcanzar el bien divino y el deseo de no querer la vía que conduce hacia él produce la parálisis expresada en la apatía - desgano 
frente a las actividades cotidianas - y en el ensimismamiento que abre las condiciones para el engendramiento de las ensoñaciones y delirios. En este mal ético, la tristeza, la apatía, la soledad y la ensoñación son concomitantes, y simultáneamente son sus causas y sus efectos. Los aspectos característicos de la acidia son atestados por Antonio.

El ocaso del día. Descuidando de sus actividades cotidianas, el eremita no ha hecho sus oraciones, no ha bajado a buscar agua al río, no ha ordenado sus pocos haberes, no ha puesto en orden su cabaña; no ha cogido sus herramientas y no ha tejido sus esteras. Antes, sus más insignificantes acciones le parecían deberes que no tenían nada de penoso. La tristeza, bloqueando la fuerza requerida para la actividad manual y oratoria, dispone el ensimismamiento de su alma y los delirios de su imaginación. San Antonio siente seco el manantial de misericordia que antes se derramaba del cielo sobre su corazón. En su soledad, como en lontananza retrospectiva, fija su atención en el pasado lejano de su vida, se torna viva la imagen del adiós a su madre y a su hermana, y viene a él la imagen de la amada Ammonaria, con su túnica abierta, sus caderas: "[...] y ya no volví a ver a nadie» (Flaubert, 1983, p. 52). Viene la imagen de la abandonada tumba de un faraón donde habitó completamente solo y por largo tiempo, donde sufrió el acecho de demonios y aves y escorpiones y otras bestias; luego, su ida a Alejandría y la formación que recibió del sabio anciano Dídimo. Recuerda cuando su ascesis llegó hasta el extremo de no temer más a Dios; recuerda cuando a él venían monjes y varios hombres para hacerse anacoretas; de todas partes recibía mensajes y de muy lejos venían a verlo; en muchas partes convocaban su ayuda para luchar contra los herejes; evoca uno de esos lugares donde vio azotar una mujer desnuda amarrada a un poste, ella se parecía Ammonaria. Se esfuerza el buen Antonio: "iNo!, ¡no!, ¡no quiero pensar en ello!» (Flaubert, 1983, p. 54). Seguidamente, viene la imagen de Atanasio, de sus discípulos y de Hilarión quien era para él un hijo; pero, «[...] todos mis discípulos me han abandonado, Hilarión como los otros» (Flaubert, 1983, p. 
54). Continúa el flujo de cuadros: los viajes hechos, los tiempos pasados con los monjes, las viviendas, los fieles, la comida: ${ }_{i} \mathrm{De}$ dónde viene mi obstinación en continuar semejante vida?» (Flaubert, 1983, p. 55). Imagina si tal vez le hubiese sido mejor hacerse gramático, o filósofo, o soldado que anacoreta. Recuerda la opulencia de los comerciantes. Y ahora «iQué soledad! ¡Qué aburrimiento!» (Flaubert, 1983, p. 57). Antonio ríe amargamente, la memoria de lo vivido y de los desprendimientos ascéticos se revierte en su presente:

¡Qué vida la de estar retorciendo al fuego palos de palmera para hacer cayados, y hacer cestas, coser esteras, luego intercambiar todo esto con los nómadas por pan que os rompe los dientes! ¡Ah!, ¡pobre de mí! ¡No se acabará esto! ¡Basta!, ¡basta! (Flaubert, 1983, p. 57).

La soledad, la desidia y el fastidio por las actividades diarias presiden la primera serie de recuerdos e imaginaciones. Esta plétora de imágenes es inmanente a la percepción de la ausencia de la misericordia - fuente de la verdad y fuerza de la ascesis-. Perdido en su confuso delirio y en su amargo laberinto, el acidioso anacoreta estalla en sollozos, se echa por tierra; mas la vista de la sombra que sobre el piso proyecta la cruz, lo remueve: « Tan débil soy, Dios mío! ¡Ánimo, levantémonos!» (Flaubert, 1983, p. 57). Antonio busca su único libro, su libro de salvación, su libro de la verdad.

En su obra Vida de San Antonio, Atanasio narra que cuando venían los anacoretas con miedo a implorar el auxilio de Antonio para protegerse de los ataques de los demonios, este les decía no temer por sus vidas. Dios solamente les ha dado a los demonios el poder de jugar con sus pensamientos; por consiguiente, la lectura del libro de la verdad y la palabra de Dios sería su salvaguarda. Ahora, en su propia confusión, Antonio intenta: «iSi tomara... la vida de los Apóstoles?... ¡Sí!, ¡por cualquier sitio!» (Flaubert, 1983, p. 57). Pero la salvaguarda se subvierte: abriendo el libro 
de la verdad y leyendo al azar algunos pasajes, hace saltar de él montones de tentaciones. El teatro alethúrgico hará saltar de la Biblia misma la primera serie de tentaciones, mas, ¿de qué modo el libro de la verdad contiene al mismo tiempo las tentaciones que niegan el acceso y desvían de la verdad? El cristianismo de los primeros siglos ha introducido en la cultura occidental la idea de la dudosa procedencia de los pensamientos y la inquietud por el origen material de los pensamientos. En el mundo grecolatino la preocupación por el contenido de los pensamientos es constante, mas la idea de enfocar la atención en el origen de los pensamientos era inconcebible. En el cristianismo, en el espacio de la vida prosaica, Dios ha dado licencia al diablo para jugar con la salvación de los hombres recurriendo a las pasiones y aspiraciones, a los afectos y los deseos como blanco del desvío en el espacio propio de sus vidas cotidianas.

En el espacio religioso de ascetas, monjes o anacoretas, el juego de los demonios cae sobre su vida espiritual. O bien mis pensamientos proceden de Dios y son verdaderos o bien mis pensamientos proceden del diablo y son falsificados. No es el contenido de un pensamiento en relación con las cosas que determina su validez, sino su fuente. Antonio lee el libro sagrado, mas la interpretación y la representación proceden del pensamiento de Antonio, pensamiento objeto del juego de los demonios, luego de la figura mayor —el diablo mismo jugará con el pensamiento de Antonio, confundiéndolo hasta subvertirlo-. Las tentaciones sufridas por el eremita son la falsificación que introducen sus propios pensamientos, y cuyo origen está en el diablo. Los sombríos agentes de alucinación, desviación y distracción llevan los pensamientos de Antonio a conferir valor existencial a todo aquello que sustrae la vida de su reducción a lo elemental. Las tentaciones son tales en cuanto trastocan los valores ascéticos. Las tentaciones, representadas en comidas, riquezas, venganzas, famas, en compañía, conversaciones con otros y reconocimiento, en el poder, en la lujuria, etc., saltan de la Biblia y pasan a los escenarios vividos por Antonio en su periplo 
ascético. Por ejemplo, la reina de Saba es la misma que ha tentado a Salomón, en esa imagen se envuelve el conjunto de los pecados capitales, que Antonio combatiera otrora en sus progresos ascéticos. En su paroxismo, Antonio deviene en Nabucodonosor; y la sangre que corre en sus alucinaciones es la de los herejes. La verdadera vida es falsificada. Los valores falsificados atraen al eremita, lo confunden, lo alteran, lo excitan y lo escandalizan; mas su equipamiento ético y su templanza lo protegen de sucumbir ante esta primera serie de tentaciones.

Así pues, el Señor quería que su apóstol comiese de todo... mientras yo... [...].

Abre el libro por otro lado [...].

¡Ah!, ¡eso está bien! El Altísimo exalta a sus profetas por encima de sus reyes $[\ldots]$ hojea al azar páginas del libro [...].

Me figuro... que se verían, en una pila hasta el techo, piedras finas, diamantes, daricos [...].

Pasa rápidamente las hojas.

¡Ah! Aquí está:

"La reina de Saba, conociendo la gloria de Salomón, fue a tentarlo, proponiéndole enigmas" [...]. ¡El diablo no tuvo inconveniente en tentar a Jesús! Pero Jesús triunfó porque era Dios, y Salomón, quizás gracias a su ciencia de mago. Es sublime aquella ciencia (Flaubert, 1983, pp. 58-59).

Seguidamente, la sombra proyectada de los brazos en cruz se transforma en dos grandes cuernos, la sombra de Cristo deviene en la imagen del diablo, visibilidad que redobla la idea de las tentaciones que saltan del libro de la verdad. Antonio pide socorro a Dios mas, rápidamente, considera que la visión es una ilusión, aunque había creído sentir la cercanía del demonio. Reflexiona sobre el nivel alcanzado en su ascesis, lo que ha hecho, las pruebas y tentaciones superadas. ¡Cómo habría de sentir temor por la presencia del diablo! Para qué iba a venir aquel si él conoce sus artificios; si él logró rechazar al falso anacoreta que, riendo, le ofrecía panecillos calientes; si rechazó al centauro que lo quería subir a su grupa, si rechazó al hermoso niño llamado espíritu de 
la fornicación; si por orden suya se han construido multitud de retiros para anacoretas; si ha curado enfermos; si ha expulsado demonios; si ha pasado el río en medio de cocodrilos; si el emperador Constantino le ha escrito tres cartas, si Balacio, que lo maldijo, fue descuartizado; si el pueblo de Alejandría se peleaba por verlo cuando iba; si hace ya más de treinta años que está en lo desiertos, si ha llevado ochenta libras de bronce en su espalda; si se ha expuesto a la picadura de los insectos; si ha permanecido cincuenta y tres noches sin dormir; si su virtud es grande tras haber expuesto su vida en un continuo martirio ascético. Pero, «[...] si comiera..., una sola vez, un trozo de carne» (Flaubert, 1983 , p. 62). Se desenvuelve la primera serie de tentaciones, las imágenes pasan «como si la ligadura general de su ser se deshiciera [...]» (Flaubert, 1983, p. 64). Se suceden los siete pecados capitales, y luego, la reina de Saba. Antonio resiste, hace la señal de la cruz; la deslumbrante, lujuriosa y grotesca reina desaparece. Si bien el eremita ha visto lo que ha deseado ver, las visiones no han logrado atraparlo. Agon ascético. Si bien el equipamiento ético de Antonio lo salva de lanzarse tras los valores y placeres de sus delirios prosaicos, los cimientos de su ascesis colapsan. Bajo el signo de la fuente seca de la misericordia, La tentación introduce sutilmente un vector hermenéutico, Hilarión va a poner ante los ojos del eremita su verdad horrible, cruel, desnuda; los propios y mal refrenados deseos de su corazón son la fuente de sus graves tentaciones y de su recia ascesis:

Hipócrita quien se refugia en la soledad para entregarse mejor al desenfreno de sus ansias [...]. ¿Es que Jesús era triste? [...]. Tú no te compadeces más que de tu miseria. Es como un remordimiento que te agita y una demencia feroz que te hace rechazar la caricia de un perro o la sonrisa de un niño (Flaubert, 1983, p. 90).

Con su juego hermenéutico, Hilarión subvierte la dura ascesis del eremita. La castidad, una corrupción más sutil; el desprecio del mundo de los hombres, la manifestación de la impotencia del odio contra él; el desprecio y la impotencia del odio vuelven 
a los ascetas lúgubres; mas también esa disposición sombría y funesta proviene de la duda, de la no posesión de la verdad. El eremita solo se compadece de su miseria, el remordimiento que lo agita y su demencia feroz son la fuente de su rechazo a lo tierno y lo alegre del mundo. Al final de La tentación, en las versiones de 1849 y 1854, cuando Antonio da gracias a Dios, el diablo le dice: "iQué importa, puesto que los pecados están en tu corazón y la desolación rueda en tu cabeza!» (Flaubert, 1908, p. 530). El eremita puede apretar su cilicio, ayunar, desgarrarse, buscar las palabras santas, hacer las más grandes penitencias; pero sentirá correr en su carne herida efluvios de voluptuosidad. Su estómago vació evocará los festines, las palabras de su oración se transformarán en exclamaciones de desespero, la satisfacción de sus méritos ascéticos lo llenarán de orgullo, la fatiga de su virtud le infundirá la envidia. Y

¡Cuando la concupiscencia de las cosas te haya dejado, entonces vendrán más desordenadas las avaricias del espíritu, y tu golpearás con la cabeza las piedras del altar; tu besarás la cruz, ipero la llama de tu corazón no calentará nada su metal! ¡tu [sic] buscarás un cuchillo... ¡Yo volveré, yo volveré! (Flaubert, 1908, p. 530).

El diablo volverá a tentar la carne de Antonio o, mejor, volverá a emerger, pues nunca se ha ido, él es parte de su corazón. Volverá a tentar su pensamiento, pues es parte de su cabeza. En La tentación, el sistema de racionalidad de la ficción literaria traduce la idea cristiana de la naturaleza pecadora del hombre en los deseos del corazón y del pensamiento. Antonio ha de clamar a Dios su misericordia, mas cuando siente la fuente seca, se encuentra solo consigo mismo. Cuando el gran parcours del diablo alcance los confines del mundo y Antonio vea nacer la vida, se encontrará en este mismo punto de partida. 


\subsubsection{Chrêsis de la verdad}

Haciendo uso de la verdad en su vida, Antonio se afecta y, afectándose a sí mismo, afecta la verdad. ¿Cuál es el precio que el saber ha de pagar por una vida ascética?, es decir, ¿qué se debe conocer de la verdad y de sí mismo a fin de aceptar la renuncia ascética? Cuando la visión de la reina de Saba ha desaparecido, Antonio cree ver uno de sus sirvientes que tal vez se ha quedado rezagado, es un niño pequeño como un enano, fornido como un cabiro, deforme y de aspecto miserable; cabellos blancos cubren su cabeza prodigiosamente grande; tirita de frío bajo su túnica y guarda en su mano un rollo de papiro. Antonio le pregunta quién es, el niño le responde: «†Tu antiguo discípulo Hilarión!» (Flaubert, 1983, p. 64). Pero, él no le cree y le dice: «Hilarión vive desde hace muchos años en Palestina» (Flaubert, 1983, p. 87). Replica Hilarión: «[...] no estuve tan lejos como piensas [...]. Debes saber incluso que nunca te he abandonado. Pero tú pasas largas temporadas sin darte cuenta de mí» (Flaubert, 1983, p. 88). Este conoce todo lo de Antonio, está en su pensamiento. Ese niño, marchito, joven como el conocimiento cuando se despierta y viejo como el saber cuándo se asienta, es la signatura del conocimiento de la verdad. En el espesor del presente de Antonio y de la bruma milenaria que le antecede, la irrupción del antiguo discípulo abre la cuestión del conocimiento de la verdad a través de un juego lógico (en las dos primeras versiones de La tentación, La lógica es un personaje).

Esta criatura retoma la vida de ascesis de Antonio intentando removerlo. Para el eremita, «El hombre, en tanto espíritu, debe retirarse de las cosas mortales. Toda acción lo degrada. [Él dice] Yo quisiera no sostenerme en la tierra - ¡ni siquiera en la planta de mis pies!—» (Flaubert, 1983, p. 90). Misticismo extremo, vida contemplativa absoluta. A su guía espiritual de otrora, el mal discípulo objeta sus sufrimientos, su soledad, su ayuno, su castidad y su tristeza. ¡Abyecciones de su corazón! Una idea retumba, «la posesión de la verdad da alegría» (Flaubert, 1983, p. 90). Antonio 
reafirma y hace valer su sufrimiento bajo la garantía de estar bendecido por Dios. En este punto, introduciendo un juego de lógica, Hilarión opera el advenimiento de las pruebas de la verdad. Le responde: "¡Admira entonces a los montanistas! ¡Superan a todos los demás!» (Flaubert, 1983, p. 91). Si el sufrimiento es la vía de la salvación, Antonio debería seguir a los montanistas, los cuales han llevado el sufrimiento más allá del límite de todas las otras sectas y, por lo tanto, estarían más bendecidos por Dios. Por consiguiente, si la cuestión del valor de la ascesis se sitúa en el sufrimiento, no importaría ni la doctrina ni la verdad. Repostando, el eremita más se enreda: “¡Pero es la verdad de la doctrina que hace el martirio!” (Flaubert, 1983, p. 91). Se abre la gravedad de la cuestión, Hilarión lanza la complejidad del asunto y la debilidad del argumento al preguntar: «¿Cómo puede él probar su excelencia, si atestigua igualmente por el error?» (Flaubert, 1983, p. 91). El eremita tiene fe en la verdad de su doctrina, fuente de su valor y su fuerza; mas los otros también. Estremecido por los razonamientos del mal discípulo, este último no quiere escuchar más. El pérfido discípulo insiste:

[...] ya vuelves a caer en tu pecado de siempre, la pereza. La ignorancia es la espuma del orgullo. Se dice: "mi convicción es firme, ¿por qué discutir?”, y se desprecia a los doctores, los filósofos, la tradición y hasta el texto de la Ley que se ignora. ¿Crees tener en tus manos la sabiduría? (Flaubert, 1983, p. 92).

El deseo de conocimiento de la verdad y el trabajo para alcanzar el conocimiento son puestos como el valor propio del hombre. «Los esfuerzos para comprender a Dios son superiores a tus mortificaciones para conmoverlo. No tenemos más méritos que nuestra sed de Verdad»(Flaubert, 1983, p. 92). Hilarión situándose bajo la perspectiva de la verdad moderna- induce la idea de que la religión sola no explica todo; la solución de los problemas desconocidos por Antonio podría hacer de la fe algo inatacable y más elevado. Por consiguiente, el estudio de las razones y de las letras antiguas no ha de despreciarse. La posición 
del primero puede ser formulada así, solamente un poco de vida es necesaria para quien quiere conocer verdaderamente la verdad; y la del eremita: solamente un poco de luz de la verdad es indispensable para quien quiere vivir verdaderamente. En la dimensión del saber de espiritualidad es suficiente una fe elemental en la verdad en cuanto se trata de la salvación, y no de la búsqueda del conocimiento de la verdad.

Cuando en el pasado, Antonio encontró su discípulo quien contaba con quince años. Este le planteaba cuestiones a cada momento, atento y pensativo lo escuchaba; era un hijo para el eremita. Ahora, Hilarión lo invita a sentarse en la piedra grande como otrora, cuando lo llamaba «clara estrella de la mañana» y las lecciones comenzaban. Resurgen sus preguntas, mas esta vez son flechas agudas y mortales dirigidas a atravesar el blanco. El buen eremita tiembla. Ávido de ciencia y ambicioso de conocimiento, Hilarión conoce muy bien la Sagrada Escritura y la techné de interpretarla. Ahora conduce su antiguo maestro, primero lo lleva a la teología, a sus interminables discusiones y a sus graves herejías; después a la resurrección de las antiguas civilizaciones con sus profetas y sus divinidades, las cuales pronto se vuelven cenizas. También los sabios y filósofos hacen su desfile. Hilarión, crece en la medida en que penetra las cuestiones brumosas del conocimiento; cuando ha traspasado los conocimientos heréticos, alcanza un tamaño colosal; cuando bordea los límites del conocimiento infinito, se ha transfigurado. Ese niño grotesco ha devenido en el conocimiento de la verdad de los tiempos modernos. Bello como un arcángel, luminoso como el sol y tan grande, que para verlo Antonio levanta su cabeza; Hilarión va vestido de eremita - visibilidad del mal refrenado deseo de conocimiento de Antonio-.

El antiguo discípulo deviene en un diablo muy particular, moderno, filosófico y spinozista. Transporta al eremita, lo lleva por los aires y lo eleva más; los dos ascienden más allá de la luna, alcanzan las estrellas, la vía láctea, las constelaciones y demás astros. 
Antonio goza del descubrimiento del mundo, de su enormidad sin límite. Con los brazos abiertos va apoyado en los cuernos del diablo ocupando toda su envergadura. El conocimiento de la verdad lo saca de su estrechez: «¡Ah!, ¡más alto!, ¡más aún!» (Flaubert, 1983, p. 209). Anonadado por el poder de Dios, ahora entiende que la materia también forma parte de él. "Así como el firmamento se eleva a medida que subes, crecerá con la elevación de tu pensamiento; y sentirás aumentar tu gozo después de este descubrimiento del mundo, en este ensanchamiento infinito» (Flaubert, 1983, p. 209). Pero el goce va a romperse cuando, con sus explicaciones, el diablo filosófico lleva al extremo límite el ejercicio del conocimiento racional del mundo. El ignorante anacoreta no puede aceptar que sus sufrimientos ascéticos acabarían tan inútiles como una mentira en el espacio, como un grito de pájaro, como un remolino de hojas muertas. ¡Llora! Y se obstina en creer que hay una gran alma: Dios que ha creado y conduce todo y, tal vez, le ama. Rodeado de tinieblas, desfallece Antonio, su conciencia estalla ante la dilatación del vacío como fuegos artificiales. El diablo le pide que lo adore, mas «Antonio levanta la vista en un último gesto de esperanza» (Flaubert, 1983, p. 215). El conocimiento racional del mundo ha llegado a su extremo límite: «No tenemos más mérito que por nuestra sed de lo Verdadero» (Flaubert, 1983, p. 92). Mal refrenada, la avaricia de conocimiento ha habitado el eremita: la voz del diablo «[...] le parece el eco de su pensamiento, una respuesta de su memoria» (Flaubert, 1983, p. 207). En La tentación, el régimen moderno de conocimiento de la verdad paga su precio por la operación de deshacer el régimen de verdad de la espiritualidad. Elevándose al infinito, rebasando sus límites y sus condiciones de posibilidad, el conocimiento deshace también la verdad propia de su régimen, solamente deja subsistir el deseo de conocimiento de la verdad. El pensamiento spinozista (a la manera del siglo XIX) del diablo conduce a Antonio a la dimensión de un escepticismo de contornos nihilistas. Desfondada la verdad de los regímenes de saber, la forma de vida pierde su base verdadera. 


\subsection{Bêtise}

Haciendo uso de la bêtise, el pensamiento de la forma de vida ascética se afecta a sí mismo. ¿Cómo es posible una vida ascética sin verdad? El eremita ha perdido la última esperanza de sobreponerse a la nada de la verdad del pensamiento y a la nada del pensamiento en su verdad. Un escepticismo formidable lo habita:

¡Ah!, ¡es el diablo! Ya me acuerdo; ¡incluso él mismo me repetía lo que aprendí del viejo Dídimo sobre las opiniones de Jenófanes, de Heráclito, de Meliso y de Anaxágoras, sobre el infinito, la creación, la imposibilidad de conocer nada! ¡Yo que creía poder unirme a Dios!

Riendo amargamente:

¡Ah!, ¡locura! ¿Es culpa mía? ¡La oración me resulta intolerable! ¡Tengo el corazón más duro que una roca! ¡Antes desbordaba de amor!... [...]. ¡Oh, encanto de la oración, felicidad del éxtasis, regalos del cielo... en qué han devenido! (Flaubert, 1983, pp. 216217).

Exterior al eremita, la fuente de misericordia ya no se derrama sobre su duro corazón, los regalos del cielo han desaparecido. Y una vez más vuelve la imagen: «[...] cuando era niño [...]. Mi madre, a mi lado, me miraba. Ella me habrá maldecido por haberla abandonado [...] y su cadáver [...]. ¡No, Ammonaria no la habrá abandonado! ¿Dónde está ahora Ammonaria?» (Flaubert, 1983, p. 217). Estas imágenes abren el espacio a la irrupción de la visión de la muerte y la lujuria; la desesperanza de Antonio es patética. Las dos damas exponen sus lastimeros atractivos: en el borde del precipicio, una fuerza atrae, un solo movimiento es suficiente para poner fin a la angustia; en el otro lado, una fuerza seduce, el divertimiento extravía del desespero. Seductoras: o bien la una o bien la otra, en cualquier caso es igual: imposibilidad de salvación. En su vacío vertiginoso, en un último esfuerzo, Antonio convoca nuevas visiones: 
Debe haber, en alguna parte, figuras primordiales, cuyos cuerpos no son más que las imágenes. ¡Si se pudiera verlas, se conocería el vínculo de la materia y el pensamiento, en lo que el Ser consiste! Son esas figuras que estaban pintadas en Babilonia sobre la muralla del templo de Belus, y ellas cubrían un mosaico en el puerto de Cartago. Yo mismo he percibido a veces en el cielo como formas de espíritus. Los que atraviesan el desierto encuentran animales que sobrepasan toda concepción [...] (Flaubert, 1983, pp. 224225).

El eremita, inclinado al pensamiento spinozista del diablo, clama por ver figuras arquetípicas, figuras antes de las figuras de sus particiones, figuras en las que el pensamiento no se diferencia de la materia, el Ser. Desea ver lo indeterminado. Entonces irrumpe la Quimera y, tras de ella, la Esfinge. Presente en las tres versiones de La tentación, 1849, 1856, 1874, esta escena cada vez alcanza mayor precisión sin sufrir cambios substanciales. En la última versión su ubicación se modifica. En las dos primeras, las dos figuras legendarias se sitúan en la mitad de la obra, abren el tránsito hacia la serie de visiones alegóricas, religiones del pasado y a la serie de pueblos y animales fantásticos; en la última, anteceden al complejo movimiento final. La escena de la Quimera y la Esfinge no comporta propia y directamente ninguna tentación para Antonio; su diálogo - muy frecuente en el siglo XIXsobrevuela el problema histórico del saber y sus relaciones con la vida de los hombres. La Quimera, aérea, muy veloz, demasiado loca, induce en los hombres paraísos en las nubes, felicidades lejanas, fantasías, los pensamientos del origen y armonía de los mundos. Lanzados por ella, los hombres se esfuerzan por realizar sus ilusiones en el mundo: «[...] yo busco perfumes nuevos, flores más largas, placeres improbados. Si percibo en alguna parte un hombre cuyo espíritu reposa en la sabiduría, yo lo tumbo de lo alto, y lo estrangulo» (Flaubert, 1983, p. 227). La Esfinge, desconocida, muda, demasiado pesada, inmóvil, pegada a la tierra, guardando y mirando su secreto, es la fuerza del pensamiento que amarra los hombres hasta hundirlos: «[...] todos aquellos que el deseo de Dios atormenta, yo los he devorado» (Flaubert, 1983, p. 227). 
La Esfinge es la visibilidad del oculto secreto del saber absoluto y eterno, propio de la antigüedad, la ciencia en sí, aquella que carece de auto-conciencia. Escribe Flaubert en el dossier de La tentación de 1849:

[...] la ciencia, el niño con cabellos blancos, representa la ciencia moderna, aquella que enseña, la Esfinge, la ciencia en ella misma, aquella que se ignora: el uno, la ciencia moderna analítica, filosófica (sin familia, ¿sin corazón?) la otra, la ciencia antigua (como se cita en Vadé, 1977, p. 73).

Hilarión -el diablo filosófico moderno-: visibilidad de la ciencia moderna que, enseñando y destruyendo el saber de lo absoluto y eterno, conlleva también a la imposibilidad de alcanzar la verdad absoluta del saber de conocimiento moderno. Muda, guardando su secreto, la Esfinge llama a la Quimera para distraer su tristeza; ligera y alegre, esta última arroja fuego al rostro de la primera, la llama para satisfacer el deseo que la devora. Mutuamente se atraen las dos figuras míticas; si los deseos, si las ilusiones se unieran con la verdad de lo absoluto y lo eterno... Pero, demasiado loca, la Quimera no puede convivir con la Esfinge; demasiado pesada, la Esfinge no puede seguir a la Quimera. Imposible la copula de Fantasía y Secreto, la Esfinge se hunde en la arena y la Quimera se aleja describiendo círculos. La Esfinge deja ante los ojos de Antonio el desierto; la Quimera, con el aliento de su boca, produce una niebla en la que el eremita después de percibir nubes arremolinadas, curvas borrosas, va a distinguir figuras que aparentan cuerpos humanos, y a las cuales le seguirán otras figuras cada vez más grotescas hasta el advenimiento de

[...] unas pequeñas masas nebulosas, del tamaño de la cabeza de un alfiler y provistas de pestañas a su alrededor, agitadas por una vibración. Entonces, delirando, Antonio clama: “iOh, qué felicidad! Yo he visto nacer la vida, yo he visto comenzar el movimiento. La sangre de mis venas late con tanta fuerza que va a romperlas (Flaubert, 1983, pp. 236-237). 
Las quimeras, el vuelo de las últimas alucinaciones, muestran a Antonio la formación del mundo en una secuencia retroactiva hasta llegar al nacimiento de la célula a partir de la materia. Antonio alcanza el contento al ver nacer la vida: en su furor desea «iser la materia!»; quiere devenir en animal, en planta, en roca; acurrucarse bajo todas las formas, penetrar los átomos. En el oleaje del vacío, en su vértigo, la forma de vida lanza su ancla en el punto donde reina la indiferenciación de espíritu y materia, de lo visible y el ser. La fe del eremita renace, deviene en el deseo alegre de resentir el todo; de ser el magma en su bêtise formidable, eterna y primigenia; de ser la materia antes de las particiones y aparentes separaciones, ahí donde el saber aún no ha nacido. Antonio encuentra su salvación y el fin de su melancolía en lo irracional, en la bêtise, en el furor de acurrucarse bajo todas las formas. El deseo del eremita alcanza su real en la materialización bestial del rostro de su Jesucristo:

Por fin, se hace de día; y como los velos de un tabernáculo que se descorren, unas nubes de oro, enrollándose en grandes volutas, dejan ver el cielo.

Y justo en el centro del mismo disco solar, resplandece el rostro de Jesucristo.

Antonio hace la señal de la cruz y se pone de nuevo en oración (Flaubert, 1983, p. 237) [Las cursivas son del autor].

La felicidad bestial y formidable es suficiente para disolver la melancolía que ha dado engendrado el montón de alucinaciones. Disuelta la acidia, disuelto el delirio. El punto de inicio de $\mathrm{La}$ tentación lo instaura la primera didascalia $\mathrm{y}$, siguiéndola, el primer monólogo de Antonio; el punto final, la última didascalia y, precediéndola, el último monólogo de Antonio. El «hilo del collar» va de la irrupción de la melancolía, que opera el bloqueo de la ascesis, a su disolución, la cual opera su retoma. Mas en el tedium vitae, está plegada la puesta en cuestión de la verdad y la forma de vida. 
El sistema de racionalidad instaurado por el tiempo de narración de La tentación es análogo al de Fausto de Goethe una de las fuentes de Flaubert-. Esta obra, después de su preludio y su prefacio, se abre con la melancolía de Fausto y se cierra con su salvación. ¿Es el «mal del siglo» (engendrado por la bêtise del siglo XIX) o las tentaciones que presiden La tentación? A primera vista el título podría permitir una afirmación, sin embargo, tal perspectiva aporta poco. El título, como en el caso de Fausto, remite a un personaje devenido en un tema en la cultura occidental. La ficción literaria fija la melancolía como condición de posibilidad de las series de tentaciones que ponen a prueba la vida ascética de Antonio y sus relaciones posibles con la verdad. Ciertamente, en el cierre de la obra, la plena alegría de Antonio es la clausura de la obra; mientras que, respecto a si el eremita vence las tentaciones o si es vencido por ellas, la duda persiste. Esta incertidumbre ha estado presente en los lectores de La tentación por más de un siglo (es más, todo lector al terminar la obra se ve lanzado a esa cuestión). Al final de la obra, la alegría de haber visto nacer la vida -inmanente a la tentación metafísica - derrama de nuevo la misericordia en el corazón del eremita, y con su efluvio, diluye la melancolía. Antonio ha alcanzado el misticismo deviniendo en la bêtise «formidable» de la materia y despojándose del discurso de verdad. La manifestación del deseo de ser la materia del eremita y la expresión bestial del rostro de Jesucristo, hecho no hombre, sino materia, vinculan la bêtise de la materia y la santidad: «En ese sueño del pensamiento y la inocencia del deseo, que no sería más que el movimiento, encuentra al fin la estúpida santidad de las cosas» (Foucault, 2001d, p. 340).

En dos momentos mayores, en su primer monólogo y en el que sigue a la tentación cósmica del diablo filosófico, Antonio manifiesta el estado de su corazón: sin la misericordia divina, está seco y duro como una roca; las delicias de la oración han desaparecido, la oración le resulta intolerable. «¡Ah!, ¡demencia! ¡Demencia! ¿Es mi falta?» Antonio está solo y se encuentra solo consigo mismo. De los mal refrenados deseos de su corazón 
humano, y de su cabeza, salen las series de imágenes delirantes y las tentaciones. Los deseos del eremita, incluido el deseo de conocimiento, son la anatomía de la bêtise. La disección se opera en dos dimensiones: en la primera, la disección es la descripción, detalle a detalle, de las formas que toman los delirios de Antonio, y en relación directa con sus deseos, es decir, se disecciona la bêtise del eremita; en la segunda, incluida en el interior de la primera (como una caja en el interior de una caja), la disección se ejerce en el interior de cada cuadro de alucinaciones; la exposición meticulosa de cada una de las fantasías de los personajes que se aparecen al anacoreta lleva a su plenitud la disección y la exhibición plena de la anatomía toda de la bêtise de la humanidad. Y la última alegría bestial no es su excepción. Hiperbólica (como la duda de Descartes), la quimera de la última tentación no puede dar lugar a otra mayor, ella destruye todas las tentaciones posibles, mas su hiperbólica fuerza la hace implosionar. La tentación metafísica de la bêtise - que hace del pensamiento del ser un vacío infinito, de la verdad de la verdad una des-realización, que des-objetiva y des-subjetiva - hunde las cosas y los pensamientos en la plena indeterminación, indiferenciación. En esta cota, el tedium vitae se deshace y la tranquilidad emana en la plenitud de la ascesis.

Poniendo en jugo las relaciones posibles entre voluntad de verdady voluntad de vivir, La Tentación enfrenta grandes problemas de la cultura occidental. En su historia moderna, la cultura ha inscrito la verdad bajo un régimen de conocimiento. Una serie de reglas, un conjunto de condiciones y métodos determinados hacen aparecer la verdad, conducen su acceso, recortan y definen sus objetos, cualifican y determinan sus sujetos legítimos. El acceso a la verdad ha devenido en un proceso eminentemente técnico y su valor ha sido indexado a la demostración. Este régimen desconecta la verdad de la forma de vida del sujeto. No sin tensiones ni avatares turbulentos, lentos en su constitución y largos en su legitimación, el saber de conocimiento conquistó el saber de espiritualidad, que gobernó las relaciones entre verdad y forma de vida en la cultura occidental desde su aurora hasta finales de la Edad Media. En los 
tiempos modernos, el régimen de saber de conocimiento opera sin consideración alguna por la espiritualidad -si entiende por esta noción la modificación del modo de ser, la transformación que sobre sí mismo debe efectuar un individuo para acceder a la verdad y recibir, como en retorno, su iluminación-. En el régimen de conocimiento, en el proceso de acceso a la verdad, no hay espacio para la transformación de la forma de vida, ni tampoco hay recompensa. La única compensación posible es la acumulación indefinida de conocimientos y el desafío de constante de decir ¡un poco más! ¡Hay que correr la frontera del conocimiento! Voluntad de más conocimiento. En la historia moderna, la verdad de conocimiento ha triunfado sobre la verdad de espiritualidad mas, la tensión entre estos dos tipos de saber, no ha dejado de ser un problema del pensamiento. En esa tensión se sitúa el mito moderno de Fausto, de Marlowe, de Lessing y de Goethe. Una leyenda alemana de fines del siglo $\mathrm{xv}$, publicada anónimamente, posiblemente fuente del primer Fausto (el de Marlowe, publicado en Inglaterra). Este Fausto desea el saber para disponer del poder, y el poder para disfrutar la vida. En una época, cuando el saber de conocimiento empieza su empresa de sobreponerse al saber de espiritualidad, este Fausto del siglo XVI muestra los peligros que devienen del acceso a este último cuando se hiperboliza el deseo indefinido saber de conocimiento. En la carta XvII, Cartas sobre la literatura, Lessing esboza su Fausto como el héroe de un saber. Sometido a una metamorfosis el Fausto de Marlowe o héroe maldito del saber prohibido se salva por su creencia en el progreso de la humanidad. La espiritualidad toma la forma de saber de conocimiento, operación posible mediante la fe en el progreso. Pero de nuevo, el héroe de un saber de conocimiento desaparece en Goethe; habitado por la melancolía, Fausto busca en los valores de un saber de espiritualidad la salvación, que la cantidad de conocimientos alcanzados en las ciencias le niegan. La idea de un tipo de saber el cual reclama la transformación de la forma de vida del sujeto para acceder a la verdad, y cuyo acceso lo salva, alcanza en Goethe la más alta intensidad moderna y, a la vez, su última formulación. Fausto es el héroe de un saber de 
espiritualidad que desaparece del mundo. Con Goethe desaparece el héroe de la vida espiritual, mas el vértigo de su ausencia parece vehicularse en el nihilismo del siglo XIX.

En este Occidente que ha inventado tantas verdades diversas y moldeado artes de la existencia tan múltiples, el cinismo no cesa de recordar que muy poco de verdad es indispensable para quien quiere vivir verdaderamente y que muy poco de vida es necesaria cuando se da verdaderamente importancia a la verdad (Foucault, 2009, p. 175).

En el siglo XIX, esa idea está en el centro del nihilismo, en el que está presente la concurrencia del escepticismo y del cinismo. En el pensamiento griego se puede ver cierta proximidad entre escepticismo y cinismo: ambos movimientos se perfilan más como un estilo de vida - actitud de ser, de hacer y de decir- que como una doctrina teórica. El escepticismo despliega su actitud de examen en el dominio los diferentes saberes dejando de lado las implicaciones prácticas, mientras que el cinismo se concentra en la actitud práctica y rueda en una especie de incuriosidad frente a los saberes, aceptando algunos pocos y minimalistas principios fundamentales. En el siglo xIx, en el interior del nihilismo se ve una especie de combinación entrecruzada de escepticismo con cinismo. Si se toma el nihilismo no como el destino fatal de la metafísica occidental, tal como lo hacen derivar las formulaciones de Nietzsche y Heidegger, sino como un acontecimiento, un episodio histórico del pensamiento del siglo XIX se puede considerar que el nihilismo pone el problema de la relación entre régimen de verdad y estilo de existencia.

Cinismo y escepticismo han sido dos maneras de poner el problema de la ética de la verdad. Su cruzamiento en el nihilismo bien manifiesta algo esencial, central en la cultura occidental [...] allá donde la preocupación de la verdad la pone sin cesar en cuestión, ¿cuál es la forma de existencia que permite este cuestionamiento?, ¿cuál es la vida necesaria desde que la verdad no sería necesaria? La cuestión del nihilismo no es: si Dios no existe, 
todo está permitido. Su fórmula es sobre todo una cuestión: si yo debo afrontarme al "nada es verdadero", ¿cómo vivir? (Foucault, 2009, p. 175).

En relación con la ética de la verdad, las cuestiones puestas por el nihilismo de cierta manera tienen presencia en La tentación de san Antonio. Al final de esta obra, la ruina de la voluntad de verdad del eremita parece inducir la pregunta: ¿cuál es la vida necesaria desde que la verdad se deshace?, o, en otros términos, si la verdad es des-realizada, si «nada es verdadero», ¿cómo vivir? La idea de la bêtise cósmica, que des-individualiza y des-realiza la verdad, deviene en la línea de inflexión sobre la que se pliega la vida. Mas si la Esfinge se ha hundido con su secreto en la arena, dejando solo la visibilidad del desierto, esa idea metafísica y minimalista no puede proceder más que de la niebla que forma el aliento de la Quimera. Esa idea, en su constitución y en su consistencia, es una fantasía, una ficción, un delirio del pensamiento con el cual el pensamiento se tienta a sí mismo (ver capítulo dos). Con su «sentido histórico», sin Dios y sin creer en el progreso de la humanidad, Flaubert responde a la cuestión si «nada es verdadero, ¿cómo vivir?» La respuesta: misticismo estético. Flaubert consideró el misticismo o el ascetismo estético no como la verdad, sino como una ficción, es decir, una composición del pensamiento susceptible de dotar a la vida de una forma que la salvaría de su aniquilamiento. La ficción no designa una invención imaginativa, irreal, opuesta al ser verdadero de la realidad (toda ontología con sus pretensiones de verdad no rebasa la cualidad de ficción del pensamiento). La preocupación por la verdad deja de ser el eje de la inquietud de la vida para devenir en una especie de in-curiosidad que permite trastocar la voluntad de verdad en la voluntad de vivir, en la voluntad de dar forma a algo. La in-curiosidad, la apatía por la búsqueda de la verdad, y la fuerza que afirma la vida en el mutismo de una vida sin verdad, en el pensamiento de Flaubert comporta una signatura: bêtise. 
La tentación de san Antonio no va sin relación con el último libro de Flaubert, Bouvard y Pécuchet es «[...] como su sombra grotesca, su doble minúsculo y desmesurado» (Foucault, 2001d, p. 337). En esta obra, la espiritualidad del eremita se transforma en la bestialidad de la existencia prosaica en relación con el régimen de conocimiento de la verdad. Haciendo uso de la bêtise moderna del conocimiento, Bouvard y Pécuchet se afectan ellos mismos y afectan la bêtise, chrêsis de la bêtise. En un primer momento, tentados por el conocimiento de la verdad, el conocimiento deviene en sus maneras de vivir. Sin que nada los fatigue, esos buenos hombres ensayan todos los conocimientos, los ponen aprueba en su vida misma, sus conductas son dirigidas por los diferentes tipos de conocimiento existentes en la cultura. En su retiro campestre, su ociosidad es plenamente activa. Pasa por sus vidas una enorme cantidad de libros donde se esconde, con toda seriedad, la verdad de todas las ciencias. Todo lo que han leído y estudiado lo practican, aplican en ellos mismos la absoluta verdad almacenada en los discursos. Su tentación es creer en lo leído, su inocencia se precipita sobre el conocimiento de la verdad. Su fe se conserva intacta. El fracaso, al poner a prueba las ciencias proviene de lo exterior, la empresa es recomenzada una y otra vez. En un segundo momento, frente a los fracasos, renuncian a hacer lo que el conocimiento cree, pero jamás a creer en la práctica bestial e irracional del hacer. Bouvard y Pécuchet renuncian en términos de prueba a hacer lo que habían emprendido hacer para devenir en aquello que ellos eran antes de las pruebas existenciales del conocimiento de verdad. Se hacen fabricar un gran pupitre doble, en el que los dos reanudarán lo que hacían antes de su retiro, aquellos que habían hecho la mayor parte del tiempo de sus vidas: copiar. Van a copiar todo, inclusive su propio libro y el diagnóstico que de ellos ha hecho un doctor, tras el pedido del Prefecto de policía ${ }^{131}$ : «pues copiar es hacer nada», es la forma de la verdadera vida sin poiesis.

131 «Un día ellos encuentran (en los viejos papales de la manufactura) el borrador de una carta de Vaucorbeil a M. el Prefecto. El Prefecto le había preguntado si Bouvard y Pécuchet no eran locos peligrosos. La carta del doctor es un reporte confidencial explicando que son dos imbéciles inofensivos. Resumiendo, todas sus acciones y pensamientos, ella debe ser para el lector la crítica de la novela» (Flaubert, 1979, p. 443). 
En Bouvard y Pécuchet, el saber de conocimiento moderno es puesto a prueba como modo de vida. Este deviene en una imposibilidad como modo de vida y queda inscrito bajo el signo del afecto elemental y el ejercicio de una ocupación insulsa. La forma de vida se torna en la bêtise de su mutismo sin verdad. La vida se pliega en su movimiento, mas su movimiento despliega el monumento de la bêtise moderna.

Llega el momento de concluir este segmento. Primero, las obras de Flaubert son susceptibles de ser consideradas como una alethurgia de la bêtise. Una dramaturgia que haciendo de la vida el lugar visible de la bêtise hace visible el pensamiento de la bêtise de la existencia y de la verdad. El teatro de la bêtise lanza la vida como el testimonio visible de la verdad. Ahí, los personajes, haciendo uso de la verdad, se afectan ellos mismos y, a la vez, afectan la verdad de la que hacen uso. Las visibilidades de la bêtise hacen visibles las formas de vida en su verdad; las visibilidades de las formas de vida hacen visible la bêtise en su verdad. Segundo, en la aurora de los tiempos modernos, el pensamiento ve dos modalidades de la locura de la condición humana: un tipo de locura que se reconoce ella misma, en donde se ubica la sabiduría; y otro, la locura que, arrogante e ignorándose a sí misma, es la estulticia de los hombres en general. De manera análoga a la locura, la ignorancia toma dos modalidades: la ignorancia que sabe que no sabe y la ignorancia que cree que sabe lo que no sabe, dos formas que han hecho tránsito de Platón al humanismo escéptico. Suena la voz de Montaigne:

$\mathrm{Si}$ alguien quiere curarse de la ignorancia, ha de confesarla. Iris es hija de Taumante. La admiración es el fundamento de toda filosofía, la inquisición el progreso, la ignorancia la meta. Pero en verdad hay cierta ignorancia fuerte y generosa que en absoluto cede en honor y coraje valentía a la ciencia, ignorancia que para concebirla no se requiere menos ciencia que para concebir la ciencia (Montaigne, 1999a, XI, p. 1030). 
Un abismo se sitúa entre la ignorancia que se reconoce a sí misma y la ignorancia que se ignora; la primera, fuerte y generosa, es la impronta de un tipo de escepticismo en el que concurren las posiciones de Sexto, Cicerón y Sócrates. Tras largo y recio trabajo, examinando el conocimiento y la verdad, el pensamiento pensándose a símismo se da cierto modo en sus operaciones y define su estatuto; el escepticismo deviene en un modo de pensar, de ver el mundo y los comportamientos humanos. En el otro polo de esta ignorancia, se sitúa el dogmatismo o la terquedad, la afirmación en el juego de lo verdadero y lo falso sobre las cosas, el juicio radical sin pendiente. Sin pensar la forma matricial del pensamiento, el pensamiento, en su ignorancia y desconocimiento, se da como cogitatio natura universalis, y con ese orgulloso pensamiento da testimonio de su imagen preconcebida, prefilosófica, que hace su juego en sus operaciones. En la idea de bêtise de Flaubert se oye el eco de Montaigne: «[... ] volverme a la duda y la incertidumbre, y a mi maestra forma, que es la ignorancia» (Montaigne, 1999, L, p. 302). Flaubert se vuelve a su epoché abstracta y a su maestra forma, que es la bêtise formidable. En su pensamiento hay un tipo de bêtise fuerte y generosa que se reconoce ella misma: una bêtise que, sin forma ni fondo, es la potencia del pensamiento, su poder de pensar y su poder de no pensar, aquello que fustiga al pensamiento. Mas también hay otro tipo de bêtise que, arrogante y desconociéndose a sí misma, juzga con seguridad, afirma causas y concluye. Este último tipo, en toda su plasticidad, es el blanco de la crítica y rabia militante, sobre ella cae el "desmoralizador», el decir de la verdad desnuda, cruel, insoportable. Los libros de Flaubert son una alethurgia de la bêtise en relación constante con la vida y sus lazos con el conocimiento y la verdad. Experiencia histórico-crítica de la bêtise. 


\section{Conclusiones}

"Hay que devenir estoico cuando uno vive en las tristes épocas en que estamos» (Flaubert, 1980, p. 317) ${ }^{132}$. En su devenir, inseparable de sus tensiones y desequilibrios, la vida fustiga al pensamiento. En un mundo incapaz de proveer las necesidades que reclama la existencia, Flaubert busca proveerse de una moral estoica fundida en la estética. Sin deseo natural de conocimiento, sin buena voluntad de verdad, sin antropologías comprensivas, las inestabilidades existenciales lanzan a Flaubert a la construcción de una forma de vida y de un modo de pensamiento como la tarea capital de su existencia. Esa preocupación, esa necesidad, esa urgencia, es inseparable de la composición de una obra de arte de escritura, con la cual pasa la factura a un siglo que lo amenaza por doquier. Como un espíritu de otros tiempos, su êthos, incontenible en la bêtise moderna, deviene en la caución de una obra eminentemente contra-cultural. Flaubert hace de su estilo de vida el testimonio de la verdad del arte y de su discurso, 
una práctica del arte en su verdad. Vinculando de manera muy particular un régimen moral y un régimen estético, hace de su existencia y de su obra el vehículo moderno del cinismo como categoría moral, como actitud y acto crítico de la verdad el cual ejerce una función desmoralizante, en cuanto devuelve a la cultura su propia verdad desnuda. Bajo el signo de las relaciones entre maneras de vivir y formas de la verdad se ha desarrollado el presente trabajo.

El primer capítulo situó las condiciones históricas de la emergencia de la idea de vida-artista en el siglo xıx y las condiciones existenciales de Flaubert que lo llevaban a la composición de su vida-artista. En dicho siglo, una serie de discursos de verdad de naturalezas disímiles, con registros diversos, correspondientes a dominios distintos, entablan conexiones heterogéneas. Un régimen estético define la verdad del arte; un régimen moral define la verdad de la vida. Así, al entrecruzar la verdad de la estética y la verdad de la moral, Flaubert hace la mayor composición de su existencia. Su moral estética se hace efectiva a través de una constante práctica de sí133 o uso de sí mismo, conducida hacia su transformación y hacia la producción de un modo de ser el cual le permitía alcanzar cierta tranquilidad y libertad.

En el capítulo dos se planteó como punto de partida la idea de que la vida-artista se instaura en una experiencia histórico-crítica de la vida, cuyo operador estético-moral es la bêtise. La estupidez moderna de las maneras de vivir, de pensar y de actuar, de desear y decir, se dispone como materia de una elaboración existencial que conlleva a la construcción de un modo de vida que asegure la tranquilidad existencial y la libertad de espíritu que el siglo XIX niega. La militancia radical contra la bêtise abre el espacio a dos movimientos que se conducen por dos nociones: bêtise formidable

133 «Uno se constituye como sujeto en la relación con sí, el sujeto no es dado [...] no es suficiente decir que el sujeto se constituye en un sistema simbólico; el sujeto se constituye en prácticas reales, en prácticas históricamente analizables. Y hay una tecnología de la constitución del sujeto que, utilizándolos, atraviesa los sistemas simbólicos, pero no es simplemente por el juego de sistemas simbólicos que el sujeto se constituye» (Foucault, 2015, p. 178). 
y bêtise moderna. La primera deviene en la mayor fuente de poder del pensamiento, la contemplación del poder de pensar y del poder de no pensar, logro que le permite el despliegue de un misticismo estético; la segunda, deviene en una actitud militante contra los modos de vida promocionados o prescritos por la cultura de su siglo. Ahí se encuentra la fuente de su obra de arte de escritura, que ejerce una función crítica. La bêtise en el pensamiento y la existencia de Flaubert, puede considerarse como un operador estético-crítico que conlleva a la creación de una moral estética y a la creación de una obra que, en su veridicción eminentemente, pretende inducir efectos críticos en la cultura del siglo XIX.

El capítulo tres se enfocó en las prácticas de sí envueltas en la tecnología higiénica intelectual, las cuales conducen, reflexiva y regladamente, a la creación de un hábito de contemplación que, una vez adquirido, se instaura en la fuente de los actos y las conductas de Flaubert. La contemplación deviene en praeceptum, techné, habitus y praxis. Como precepto, es idea-regla que ordena y conduce la moral estética; como técnica, es el saber y habilidad que conduce a la producción de un tipo de vida otra; como disposición, es la actitud permanente de un modo de pensar, sentir y decir; como práctica, es la producción del êthos. En la vida-artista se bordea la ataraxia (aquello que el estoicismo ha inventado para la moral). Pero, si bien Flaubert logró dejar a un lado el lamento por el fango de la vida común de los hombres y logró protegerse de la bêtise de su siglo, jamás pudo ser indiferente a ella. A la apatheia solo se aproximó.

En el capítulo cuatro, al reconocer la imposibilidad de escapar completamente a las formaciones históricas del siglo — no se está jamás en un afuera a la historia que constituye el modo de ser, se consideró que Flaubert al estudiar el modo de ser, el êthos del siglo XIX y sus discursos, hizo jugar a la verdad otro juego, con otras reglas. Así, su juego contra-cultural pretendió inducir efectos de contra-conducta. Pero no se trata de un juego teórico el cual prometería una mejor sociedad y promovería el remiendo 
del tejido del consenso ético de su época. De esta manera, el artista escéptico se incapacita frente a la promesa del progreso y se prohíbe cualquier tipo de "deber ser». Su juego contra-cultural alcanza su realidad como cosa hecha por y sobre su propia vida. Con raíz en su modo de vida y su modo de pensamiento, sus obras de arte de escritura son una práctica veridicción, práctica de un decir verdadero que devuelve a la cultura su propia verdad de manera cruda, horrorosa, desnuda. La ética de la verdad de Flaubert no es más, no es menos, que la práctica de la verdad del arte y de la verdadera vida en la plástica de su existencia y de sus libros. Vida-artista: experiencia histórico-crítica de la vida, una experiencia histórico-crítica de la bêtise moderna.

El capítulo cinco abordó la obra de Flaubert bajo la perspectiva de una alethurgia de la bêtise. Una dramaturgia que, haciendo de la vida el lugar visible de la bêtise, hace visible el pensamiento de la existencia y la verdad. El teatro de la bêtise lanza la vida como el testimonio visible de la verdad. Ahí, los personajes haciendo uso de la verdad se afectan ellos mismos y, a la vez, afectan la verdad de la que hacen uso. Las visibilidades de la bêtise hacen visibles las formas de vida en su verdad; las visibilidades de las formas de vida hacen visible la bêtise en su verdad.

Los libros de Flaubert son una alethurgia de la bêtise en relación constante con la vida y sus lazos con el conocimiento y la verdad. Experiencia histórico-crítica de la bêtise. 


\section{Referencias bibliográficas}

Agamben, G. (2002). Moyens sans fin. Notes sur la politique. Payot \& Rivages.

. (2006). Estancias. La palabra y el fantasma en la cultura occidental. Pre-textos.

. (2016). ¿Qué es el acto de cración? En El fuego y el relato

(E. Kavi, Trad.) (pp. 35-50) Sexto piso.

. (2017). El uso de los cuerpos. Homo sacer, IV, 2 (R. Molina-

Zavalía, Trad.; 1. ${ }^{a}$ ed.). Adriana Hidalgo Editora.

Bourdieu, P. (1975). L'invention de la vie d'artiste. Actes de la Recherche en Science Sociales, 1(2), 67-93. http://www.persee. fr/doc/arss_0335-5322_1975_num_1_2_2458. 
Borges, J. L. (1974). Flaubert y su destino ejemplar. En J. L. Borges. Obras completas 1923-1972 (pp. 263-266). Emecé Editores. https://literaturaargentina1 unrn.files.wordpress. com/2012/04/borges-jorge-luis-obras-completas.pdf.

Cámpora, M. (2011). La bêtise, un privilège français? Autour de la traduction en espagnol d'un mot flaubertien. Flaubert, 6. http://journals.openedition.org/flaubert/1651.

De Chateaubriand, F. R. (1836). Histoire de la littérature anglaise, Tomo II. Furne et Gosselin.

Deleuze, G. (2011). Différence et répetition. Puf.

DíAZ, J. L. (2015). Quand la littérature formatait les vies. Contextes, 15. http://journals.openedition.org/contextes/6046.

Diderot, D. (1818). Le Salon de l'année 1767. Oeuvres de Denis Diderot, tome IV. Garnier.

Flaubert, G. (1908). La Tentation de saint Antoine III. La Revue de Paris, T. II. . (1979). Bouvard et Pécuchet (C. Gothot-Mersch Ed.). Gallimard. . (1973). Correspondance I (janvier 1830 à juin 1851) (Èditon établie, présentée et annotée par Jean Bruneau). La pléiade, Gallimard.

- (1980). Correspondance II (juillet 1851-décembre 1858) (Èditon établie, présentée et annotée par Jean Bruneau). La pléiade, Gallimard. . (1983). La Tentation de saint Antoine (C. Gothot-Mersch Ed.). Gallimard. 
. (1991). Correspondance III (janvier 1859 - décembre 1875)

(Ėditon établie, présentée et annotée par Jean Bruneau). La pléiade, Gallimard.

. (1998). Correspondance IV (janvier 1869 - décembre 1875)

(Ėditon établie, présentée et annotée par Jean Bruneau). La pléiade, Gallimard.

. (2007). Correspondance V (janvier 1876 - mai 1880) (Èditon établie, présentée et annotée par Jean Bruneau et Yvan Leclerc). La pléiade, Gallimard.

Foucault, M. (1984). Histoire de la sexualité II. L'usage des plaisirs. Gallimard.

. (2001a). L'Herméneutique du sujet. Cours au Collège de France 1981-1982. Gallimard - Seuil.

- (2001b). L'étique du souci de soi comme pratique de la liberté. En Dits et écrits II, 1976-1988 (pp.1527-1548). Gallimard.

. (2001c). Foucault. En Dits et écrits II, 1976-1988 (pp. 14501455). Gallimard.

. (2001d). Postface à Flaubert. En Dits et écrits I, 1954-1975 (pp. 321-353). Gallimard.

. (2001e). Le sujet et le pouvoir. En Dits et écrits II, 19761988 (pp. 1041-1062). Gallimard.

. (2001f). Les techniques de soi. En Dits et écrits II, 19761988 (pp. 1602-1632). Gallimard. 
- (2004). Naissance de la biopolitique. Cours au Collège de France, 1978-1979 (Ėdition établie sous la direction de François Ewald et Alessandro Fontana, par Michel Senellart). Gallimard - Seuil.

. (2009). Le courage de la vérité. Le gouvernement de soi et des autres. Cours au Collège de France, 1984 (Èdition établie sous la direction de François Ewald et Alessandro Fontana, par Frédéric Gros). Gallimard - Seuil.

. (2012). Entretien de Michel Foucault avec André Berten. En Mal faire, dire vrai. Fonction de l'aveu en justice. Cours de Louvain, 1981 (pp. 235-246) (Ėdition établie par Fabienne Brion et Bernard E. Harcourt). Presses universitaires de Louvain-University of Chicago Press.

. (2013). L'origine de l'herméneutique de soi. Conférences prononcées à Dartmouth College, 1980 (Èdition établie par Henri-Paul Fruchaud et Daniele Lorenzini). Vrin.

. (2014). Subjectivité et vérité. Cours au Collège de France. 1980-1981 (Ėdition établie sous la direction de François Ewald et Alessandro Fontana, par Frédéric Gros). EHESS Gallimard - Seuil.

. (2015). Qu'est-ce que la critique? Suivi de La culture de soi (Èdition établie par Henri-Fruchaud et Daniele Lorenzini, introduction et apparat critique par Daniele Lorenzini et Arnold I. Davidson). Vrin.

. (2016). Discous et vérité précedé de la parrêsia (Èdition et apparat critique par H.P. Fruchaud et D. Lorenzini). Vrin.

. (2017). Dire vrai sur soi-même, Conférences prononcées à l'Université Victoria de Toronto, 1982 (Éditions, introduction et apparat critique par H.-P Fruchaud et D. Lorenzini). Vrin. 
Hegel, G. W. F. (1989). Lecciones de estética I (R. Gabas, Trad.). Península.

Kant, I. (1994). Respuesta a la pregunta ¿Qué es la Ilustración? (R. Jaramillo Vélez, Trad.), Revista Colombiana de Psicología, (3), 7-10. https://revistas.unal.edu.co/index.php/psicologia/ article/view/15803/16619.

Montaigne, M. (1999). Les Essais I (Édition conforme au texte de l'exemplaire de Bordeaux avec les additions de l'édition posthume, éd. Pierre Villey, sous la direction et avec une préface de V.-L. Saulnier). Presses Universitaires de France.

. (1999a). Les Essais III (Édition conforme au texte de l'exemplaire de Bordeaux avec les additions de l'édition posthume, éd. Pierre Villey, sous la direction et avec une préface de V.-L. Saulnier). Presses Universitaires de France.

Pinard, E. (1857). Procès de Madame Bovary: Réquisitoire de Me Ernest Pinard. http://flaubert.univ-rouen.fr/oeuvres/mb_ pinard.php

Quinet, E. (1834). Une lecture à l'Abbaye-aux-Bois. Les Mémoires de M. de Chateaubriand. Revue de Paris III.

RANCIÈRE, J. (2009). La palabra muda. Ensayo sobre las contradicciones de la literatura. Eterna Cadencia Editora. . (2010). Política de la literatura. Zorzal . (2010a). La parole muette. Essai sur les contradictions de la littérature. Fayard.

Rodríguez Jaramillo, A. (2018). «Yo soy un moralista» Foucault, las alethurgias. Editorial Universidad Tecnológica de Pereira 
SAND, G. (1966). Correspondance Tome II. Garnier.

SARtre, J. P. (1988). L’idiot de la famille: Gustave Flaubert de 1821 à 1857, I. Gallimard.

Smith, P. (1844). Esquisses de la vie d’artiste. Jules Labitte.

Taine, H. (1867). Notes sur Paris: vie et opinions de M. Frédéric Thomas Graindorge. Librairie Hachette.

VADÉ, Y.(1977).LaSphinxetla ChimèreII. Romantisme,(16),71-81. https://www.persee.fr/docAsPDF/roman_0048-8593_1977_ num_7_16_5098.pdf.

Von Koppenfels, M. (2012). La main de Flaubert. Stratégies d'auto-immunisation. Trivium, 11. http://journals. openedition.org/trivium/4261.

Zabunyan, D. (2007). La bêtise: «faculté pitoyable» ou «faculté royale»? Revue Flaubert, (7), 1-17. https://flaubert.univrouen.fr/revue/revue7/zabunyan.pdf. 
Este libro terminó de imprimirse en Marzo del 2021, en los talleres gráficos de Gráficas Olimpica, bajo el cuidado de sus autores.

Pereira, Risaralda, Colombia. 
Lector, este es un libro de pliegues, su línea de inflexión es la vida-artista de Flaubert y la imagen del pensamiento plegada y desplegada en ella. El libro advierte: estudio del estilo de vida de Flaubert como el lugar visible de la verdad del arte y como la caución de una obra de arte de escritura que, diciendo la verdad, ejerce una función eminentemente contra-cultural -escándalo de la verdad-. El corpus está dispuesto en cinco capítulos entre-tenidos: el primero precisa la idea de vida-artista y desbroza las preocupaciones de Flaubert que lo lanzan a la composición de un estilo de vida particular; el segundo se aplica a la noción de bêtise (estolidez, estupidez, bestialidad) de Flaubert como operador estético-crítico de su vida-artista y de su obra; el tercero enfoca la cuestión de la búsqueda de un estilo de vida que procuren a través de la estética lo que el estoicismo ha inventado para la moral: la tranquilidad; el cuarto examina de qué manera los libros de Flaubert son una práctica de veridicción con función contra-cultural y bajo qué condiciones su práctica de veridicción estando amarrada con su êthos, despliega el principio de impersonalidad del arte; el quinto examina la alethurgia de la bêtise -manifestación visible de la estupidez) en la vida- y los efectos que induce en relación con un problema mayor del nihilismo del siglo XIX: si la verdad es des-realizada, si nada es verdadero, ¿cómo vivir, cómo conducir la vida? 